\title{
Manifestations of the Maimed: The Perception of Wounded Soldiers in the Civil War North
}

\author{
William R. Feeney
}

Follow this and additional works at: https://researchrepository.wvu.edu/etd

\section{Recommended Citation}

Feeney, William R., "Manifestations of the Maimed: The Perception of Wounded Soldiers in the Civil War North" (2015). Graduate Theses, Dissertations, and Problem Reports. 5583.

https://researchrepository.wvu.edu/etd/5583

This Dissertation is protected by copyright and/or related rights. It has been brought to you by the The Research Repository @ WVU with permission from the rights-holder(s). You are free to use this Dissertation in any way that is permitted by the copyright and related rights legislation that applies to your use. For other uses you must obtain permission from the rights-holder(s) directly, unless additional rights are indicated by a Creative Commons license in the record and/ or on the work itself. This Dissertation has been accepted for inclusion in WVU Graduate Theses, Dissertations, and Problem Reports collection by an authorized administrator of The Research Repository @ WVU.

For more information, please contact researchrepository@mail.wvu.edu. 
Manifestations of the Maimed: The Perception of Wounded Soldiers in the Civil War North

\title{
William R. Feeney
}

\author{
Dissertation submitted to the \\ Eberly College of Arts and Sciences \\ at West Virginia University
}

in partial fulfillment of the requirements

for the degree of

Doctor of Philosophy

in

History
Jason Phillips, Ph.D., Chair
Aaron Sheehan-Dean, Ph.D.
Brian Luskey, Ph.D.

Ken Fones-Wolf, Ph.D.

Elizabeth Fones-Wolf, Ph.D.

Department of History
Morgantown, West Virginia
2015

Keywords: Civil War; disability; wound; surgeon; nurse; gawker; curiosity; museum

Copyright 2015 William R. Feeney 


\section{ABSTRACT \\ Manifestations of the Maimed: The Perception of Wounded Soldiers in the Civil War North}

\section{William R. Feeney}

The Civil War produced over 350,000 permanently disabled men, in addition to millions of other types of injuries and diseases. Yet, despite the overwhelming destruction to men's bodies the war also laid the foundation for a number of notable advances. These generative changes include increased collaboration between medical professionals, an estimable reputation for individual surgeons, a budding international reputation for American medicine, nursing opportunities for upper class women, a rise in volunteerism in the north, and a public acceptance of anatomical study and exhibition. For all the prolific effects of the war, however, these transformations all required one thing, the destruction of soldiers' bodies. It is the purpose of this study to demonstrate that disabled bodies played an integral role of shaping how civilians and soldiers perceived the wreckage surrounding them while also allowing them to recognize the benefits of such destruction. This study also examines how surgeons, nurses, gawkers, and museum goers drew personal connections with broken bodies within nineteenth-century perceptions of ability and disability. 


\section{ACKNOWLEDGEMENTS}

Anyone who has ever endured the personal and professional rigors of a graduate program knows that success is not a solitary venture. Dissertations resonate with the voices of a multitude of people whose influence help to shape words and ideas. These influences take many forms; some are more formal in nature, exemplified by the guidance provided by committee members. The expertise they each share make an indelible impact on the final product. Others influence our work in ways that never broach the dissertation at all. Through friendship and support they offer moments that allow us to get away from the grind for awhile, reminding us of the importance of guilt free non-work days.

I would like, first of all, to thank the members of my dissertation committee. I am profoundly grateful to Dr. Aaron Sheehan-Dean for taking the lead on, what was, a complex committee situation. His patience and insight helped to turn a series of inchoate ideas into the content that fills these pages. Many times I sat in awe as he deftly turned ten minutes of my rambling into a central statement. Without his time and counsel this project could not have moved forward. Dr. Jason Phillips deserves special thanks for seamlessly stepping into the advisory role and shepherding me through the last stages of the defense process. I was extremely fortunate to have him on my committee and could not imagine a better scholar to help me over the final hurdles. During my time at West Virginia University, Dr. Ken Fones-Wolf taught me the merits of an effective historiographical essay. Special thanks also goes to Dr. Elizabeth Fones-Wolf who graciously agreed to join my committee shortly before the defense. Her insights will continue to prove valuable as my project continues forward. Words cannot adequately 
express my sincere gratitude to Dr. Brian Luskey for his unwavering support and dedication. For all intents and purposes, he was the academic rock that held this entire process together. His counsel, commitment, and friendship mean more than I can ever convey. While not an official committee member in the end, I want to extend Dr. Peter Carmichael a sincere thank you for his willingness to work with me these many years. He demonstrated his support a thousand times over in ways that are too numerous to list here. I will take your examples of support and friendship with me throughout my academic career and look forward to paying it forward to my own students in the years to come.

I would like to thank the history department at West Virginia University for providing me with the education, funding, and teaching experiences that come with being a graduate student. I continue to carry those lessons with me. A project such as this is not possible without generous financial support. Fellowships and grants from the Eberly School, the history department, and the Union Club of Boston provided the support necessary for research. Archivists and research centers are invaluable to the early stages of any project. With this in mind I would like to thank Laura Cutter at the National Museum of Health and Medicine for her assistance in traversing the chaotic realm of Civil War documents. The patience and guidance of staff members at the National Museum of Civil War Medicine, Army Heritage and Education Center, the Pennsylvania Historical Society, the Library Company, the Mütter Museum, and National Library of Medicine ensured that I had a stream of rich sources to engage.

I could not have endured the rigors of graduate school without the support of my friends and family. Ashley Luskey influenced my study habits early on with her 
friendship and study sessions at coffee shops around Morgantown. To Joel and Emily Christenson I extend a heartfelt thank you for your friendship throughout our time at WVU. Thanks to Karina Esposito, who not only kept me laughing for three years, but also kept me well fed. The nights with your Brazilian-style dinners are some of my most cherished memories. Joshua Esposito is not only a kindred spirit but also a true friend. Without his companionship I am not sure I would have survived living apart from my family. I owe more to you and Karina that you can ever know. It is only natural, I suppose, that Jacob Ivey proved to be the best dinner date a guy could have. We both lived in separate states from our wives and we shared a passion for burgers, wings, and inane conversation. I continue to look fondly on the many meals we shared at the local pub.

I walked onto my undergraduate campus full of doubt, anxiety, and a track record of academic failure. "College is not for everyone," a common aphorism, was hinted to me often during my first few attempts at college. By the time I arrived in Dr. Michael P. Gray's military history course I was sure that they were right. His class, though, proved to be one of the most influential turning points of my life. Not only did he genuinely care about me as a student, but believed in me in a way that no other teacher or professor had. He invited me to join him at the annual Southern Historical Association's yearly conference while still a junior and guided me through my undergraduate studies. I am a historian because of him. Today I am pleased to call him one of my closest friends. Adam Spisszak and his parents, Judy and Ed, have continued to influence me from the tender age of ten. Adam and I traveled the uncertain road of childhood, adolescence, adulthood, and fatherhood side-by side and I am grateful to him for thirty years of 
unconditional friendship. Judy and Ed opened their homes, holidays, and hearts to me during a time when it was desperately needed. I can never thank them enough. Special thanks to Ed whose love of history helped foster my own.

I would like to thank my family, both immediate and extended, for their continued support. My family exemplified the tenets of hard work and tenacity, as well as the drive to persevere regardless of hardships. I missed many family events in pursuance of my degree and I owe all of them a debt of gratitude for their understanding. This dissertation is a product of their patience. My mother, Betty, and sister, Pauline, deserve special thanks for demonstrating that time spent with one's children is worth ten times the hours spent in an archive. I held this lesson closely when Greyson was born. I offer my thanks to my extended family, Gary and Detta Bedford. They treated me as a son long before I married into the family and gave me unconditional support and love. I see you both as much more than "in-laws." I look forward to many years of coffee, baseball, and laughter with them both. After I defended the dissertation a thought came to me, one that was said the day I asked permission to ask for their daughter's hand in marriage. "It's about time!"

I am fortunate in many ways. I have a career I am passionate about, colleagues and friends who enrich my life, and the support of loving family members and in-laws. Above all though, I have a wife who has stood by my side me through the highs and lows of the dissertation process. Digger, words cannot convey how much your love and understanding has meant to me over the years. Unfailingly, you have supported my chosen path, even when it required me to live in a separate state. You played many roles throughout this process. You were my sounding board, editor, research assistant, 
colleague, therapist, friend, confidant, and loving wife. You took on each of these roles without complaint, and gave me unconditional love. I would not be here today were it not for you, nor would I want to be. I look forward to saying "yes" to nights and weekends. To borrow a lyric from one of our favored musicians, "Now my work is done. I think we're owed some joy." Greyson, the joy you bring to my far life exceeds all other accomplishments. You are the best thing I have ever done. Thank you for showing me the joys of fatherhood.

An advisor of mine once told me that the most gratifying part of the dissertation process is writing the acknowledgements. For the better part of three years I have waited to test his theory. As usual Pete, you were right. 


\section{Table of Contents}

INTRODUCTION:

CHAPTER 1: "He could snatch off a leg or arm quicker than you could say 'Jack Robinson,"”: Surgeons, Bodies, and the War .......................................

Fractious Medicine: The Antebellum Period......................................12

The Civil War Years: Engaging with Bodies........................................30

Concluding Wounds: Medical America...........................................50

CHAPTER 2: Our first day's experience, a day of horror and yet a day of blessing":

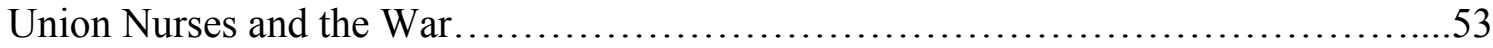

CHAPTER 3: "Gratifying Morbid Curiosity": Gawking at Wounded Soldiers...........95

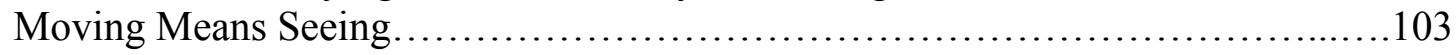

Curious Bodies: Battlefield Gawkers and the Wounded.............................103

To Mingle Among the Wounded: Field and General Hospitals..............................114

Informed Stares: The Desire for More...........................................124

CHAPTER 4: "The public came to see the bones:" Bodies on Display in Mid Nineteenth-

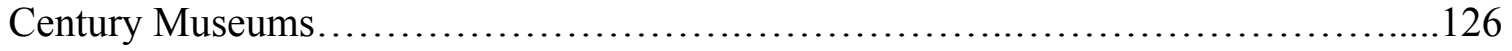

Sensation, Deformity, and Murder: The Public's Fascination Grows................132

Entertaining Disability and Deformity: The Antebellum North.....................136

The Advent of War: Soldiers, Anatomy, and Museums............................153

The Mütter Museum: Philadelphia’s Premier Medical Oddities Museum..............155

Army Medical Museum: Soldier's Bodies and Display...............................161

Conclusion: Abnormal Bodies from the Colonial Era to the Post War Period.......178

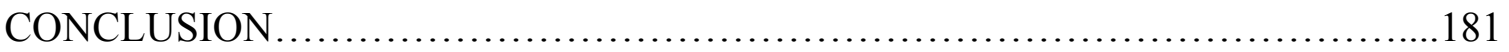

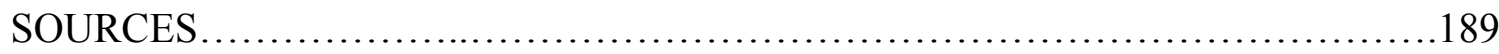




\section{INTRODUCTION}

Given that it is the primary purpose of war to cause destruction, it is little wonder that the Civil War was the most destructive conflict in our nation's history. While this statement appears rote, it bears repeating. Military organization, increases in army size, technological advances in weaponry, and rapid mobilization all coalesced to provide the opportunity for permanent injury, disease, or death in ways never before witnessed. ${ }^{1}$ The war claimed over 750,000 lives, more than every other American war combined. The movements of Union and Confederate forces led to mass slaughter, causing one South Carolinian to comment, "This world never saw such a war." In addition, towns and cities became targets of siege campaigns while smaller hamlets felt the wrath of marching armies. The South's three largest cities - Richmond, Atlanta, and Charleston, lost one third of their buildings. ${ }^{3}$ The south experienced so much destruction that it took decades before agricultural production reached its prewar levels, and generations before the South recovered financially. The war was, for all intents and purposes, the defining event of our nation. In the words of Gary Gallagher "If you don't understand the Civil War you have no chance of understanding modern America. Not a slim chance, you have no chance. None."

For all its destruction, however, the war proved to be a boon for a number of American entities. The emancipation of over four million African Americans, the

\footnotetext{
${ }^{1}$ Drew Gilpin Faust, This Republic of Suffering: Death and the American Civil War (New York: Alfred A Knopf, 2008) 4. On the size of Civil War armies, see James McPherson, Battle Cry for Freedom (New York: Oxford University Press, 1988), 306.

${ }^{2}$ Letter to Mattie J. McGraw, May 5, 1863.

${ }^{3}$ Meagan Kate Nelson, Ruin Nation: Destruction and the American Civil War. (Athens: University of Georgia Press, 2012), 10.

${ }^{4}$ Gary Gallagher, "Darden Leadership Ride Elective Course" https://www.youtube.com/watch?v=ljLOYC4pTzM\&list=PLqeTy8qygziHsuB62BCpw4zGoCg4tMF5v (accessed Saturday, August 29, 2015.)
} 
enfranchisement of black men, and the establishment of constitutional equality are some of the more significant transformations. However, the war proved to be vital for the development of a strong central government, as well as an expansion of democratic rights. The sophistication of American science and new professional fields for women also owe much to the war. Culturally, the war had a drastic impact on the way citizens viewed medicine and death. For all the prolific effects of the war, however, these transformations all required one thing: the destruction of soldiers' bodies.

It is the purpose of this dissertation to demonstrate that the generative effects of the war were not possible without the destruction of soldiers' bodies. This study places the wounds of soldiers in the center of the story and explores the varied and contested meaning of these injuries to able-bodied men and women. Examining how citizens and soldiers understood the wounded bodies before them gives us greater insight into how these viewers shaped attitudes about the way society should function. Analogous to the concept of wounded soldiers are nineteenth-century cultural ideals of disability. Men and women, whether serving in the armies or residing on the home front, relied upon familiar tropes surrounding disabled bodies to make sense of the most destructive aspect of war, even while they used those same bodies to enact positive changes.

Interpreting the role of surgeons, nurses, gawkers, and museum goers through broken bodies produced by the war provides insight into the broader cultural trends of the nineteenth-century. Chapter one examines how the antebellum medical field suffered from professional fragmentation and intense competition. So much so that the field remained stagnant for decades. American medicine suffered from a lack of reputation and low morale, which prohibited widespread professional development and an 
acceptance of modern advances. A plethora of disease and injury, however, pushed the Surgeon General to impose strict treatment and documentation requirements, thus laying the foundation for collaborative forms of universal treatment. Such behavior not only added to the quality of the medical field overall, but played an integral role in improving the reputation of American medicine. By the twentieth-century, American medicine grew to rival traditional medical establishments in Europe. Chapter two investigates how wounded soldiers provided an opportunity for female nurses to argue against their social impairments. Their letters frequently drew attention to the physical and mental requirements necessary to endure, and indeed thrive, amidst an unending relationship with death, disease, and suffering. Chapter three analyzes the impact of curiosity on civilians and soldiers as they found themselves drawn to destructive scenes of the war. It was not just a depraved sense of yearning that drew civilians and soldiers toward horrors of hospitals and battlefields. Witnessing the war with their own eyes provided an intimacy of war that was not readily available for most, even for those serving on the front lines. Walt Whitman noted during his time as a nurse in Washington D.C., "As this tremendous war goes on," public interest "gathers more and more closely about the wounded, the sick, and the Government hospitals." ${ }^{, 5}$ Chapter four explores the long relationship that citizens had with freak shows and museums in the antebellum period and finds similarities between the Barnumesque attractions and Civil War era museums. Long recognized by historians as pivotal institutions in the development of nineteenthcentury urban culture, these museums appealed to abnormality and "freakishness." These same themes surfaced during the war years as institutions like Mutter's Museum and the

\footnotetext{
${ }^{5}$ Walt Whitman, "Hospital Visits," New York Times. December 11, 1864.
} 
American Medical Museum opened their doors to a public eager to see soldiers' bodies on display.

This study takes a broad view of disability by including both long and short-term injuries or diseases into its definition. During the nineteenth-century, the term disability not only referred to physical limitations, but also viewed it in racial and gendered terms. The concept of disability served as a means to exclude certain social groups from participating in the democratizing aspects of the nation. Under the guise of "natural disabilities," women, African Americans, and immigrant groups, were forced to adhere to cultural standards that restricted their personal and social freedoms. In the upheaval of war, the overwhelming number of wounded bodies came to represent a way for some groups to bend these restrictions. The meanings of the soldiers' wounds were never static, nor were they isolated from other social and cultural trends. As with all historical constructs, the meaning of disability varied, transitioned, and was contested, from wound to wound. While some saw bodies as a means for individual, or even national improvement, others relied on orphaned limbs as a means to normalize both themselves and the destruction of war. Though able-bodied men and women understood the war through the grievous wounds of others, these chapters seek to remove moral or ethical judgments from historical actors.

Just as able-bodied northerners drew meaning from the wounds they witnessed, so too did injured soldiers interpret their interactions with the people around them. Wounded men frequently commented on the benevolence or apathy of those in their midst. Some soldiers feared societal and familial rejection as they came to terms with their injuries. Still others, like Dan Sickles, took their prewar ideals of masculinity and 
re-imagined them in the context of their newly acquired disabilities. Time does not permit me to fully engage with each facet of this complicated relationship, however, at various points this study will highlight the way in which soldiers understood the consequence of disability.

Recently, the topic of disability has appeared in a number of Civil War era studies. Brian Craig Miller's work, for example, illustrates how familiar historical themes like gender and memory benefit from the added lens of disability. As he demonstrates southern amputees reconstructed their manhood within familiar cultural tropes even going so far as to base their medical decisions on how society viewed war related injuries. Historians of Civil War medicine have studied the impact of the war on medical science in general while other scholars investigate public health initiatives. Other works include studies on the Invalid Corps, veterans' benefits, Soldiers' Homes, bureaucratic organization, benevolent associations, and nursing. These studies are just a few examples of the way injured soldiers contribute to the study of the Civil War. While disability as a theme plays a secondary role in these Civil War studies, they each recognize the impact that wounded soldiers had on their respective topics. ${ }^{6}$ Placing injuries at the center of the story uncovers the importance disability had in the development of northern society. The wounds soldiers suffered filtered the most

\footnotetext{
${ }^{6}$ Brian Craig Miller, Empty Sleeves: Amputation in the Civil War South (Athens: University of Georgia Press, 2015); Brian Craig Miller, John Bell Hood and the Fight for Civil War Memory (Knoxville: The University of Tennessee Press, 2010); Margaret Humphreys, Marrow of Tragedy: The Health Crisis of the American Civil War (Baltimore: Johns Hopkins University, 2013); Shauna Devine, Learning from the Wounded: The Civil War and the Rise of American Medical Science (Chapel Hill: University of North Carolina Press, 2014); Paul Cimbala ed., Union Soldiers and the Northern Home Front: Wartime Experiences, Postwar Adjustments (New York: Fordham University Press, 2002); James Marten, Sing Not War: The Lives of Union \& Confederate Veterans in the Gilded Age America (Chapel Hill: University of North Carolina Press, 2011); Judith Giesberg, Civil War Sisterhood: The U.S. Sanitary Commission and Women's Politics in Transition, (Boston: Northeastern University Press, 2000); George Worthington Adams, Doctors in Blue: The Medical History of the Union Army in the Civil War, (Baton Rouge: Louisiana State University, 1996).
} 
destructive elements of the war into a usable platform for surgeons, nurses, gawkers, and museum goers. 
Chapter 1 - "He could snatch off a leg or arm quicker than you could say 'Jack Robinson,"': Surgeons, Bodies, and the War

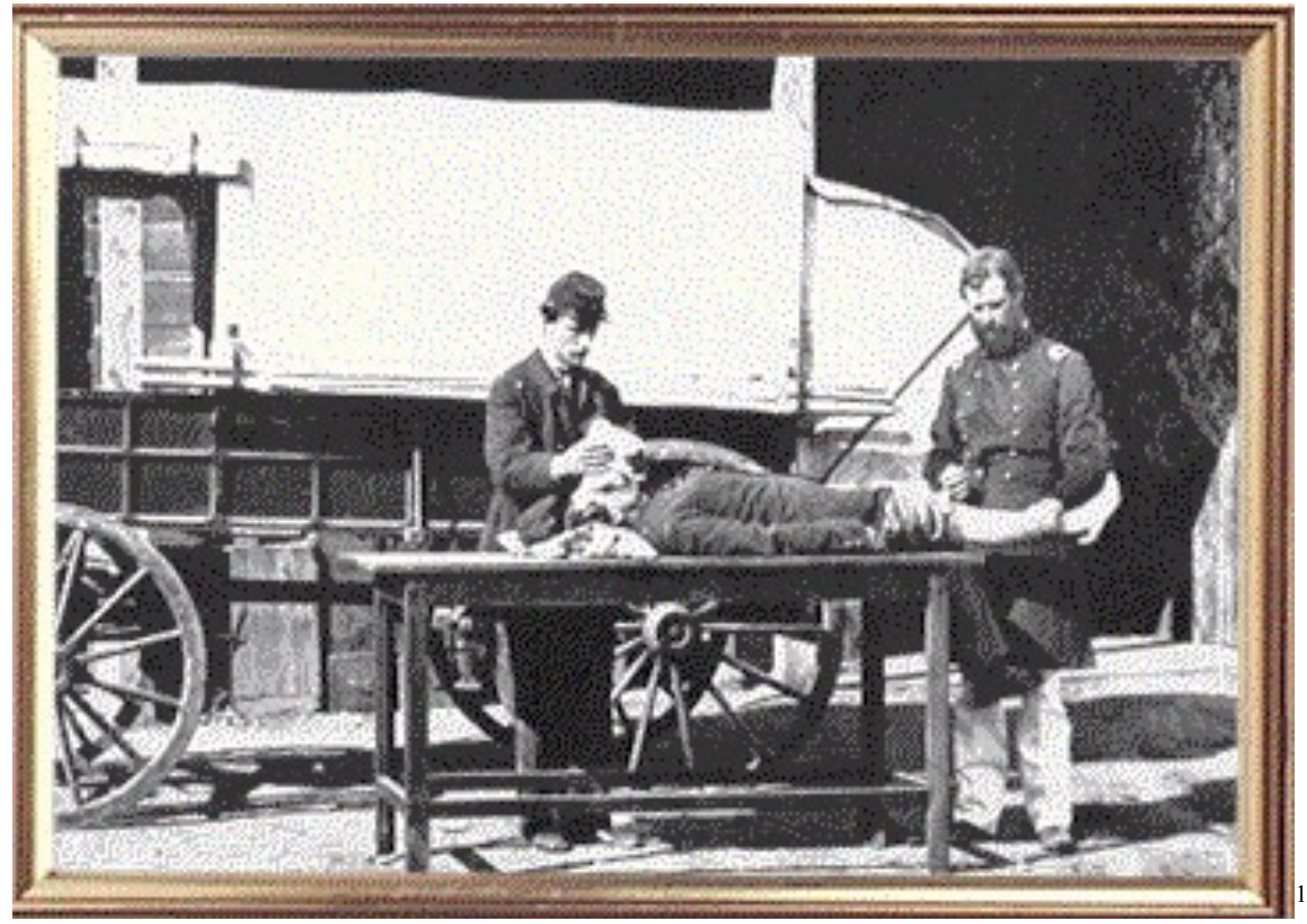

\footnotetext{
${ }^{1}$ Two surgeons prepare for an amputation. Note the surgeons' focus on their task rather than the soldier himself.
} 
John Hill Brinton was satisfied. He had just successfully performed a perilous amputation of an arm at the shoulder joint. For years his name and reputation had steadily risen in tandem with his surgical skills. As a ranking member of the Surgeon General's Office in Washington, D.C., he had accomplished much in his thirty-two years. Born in 1832 to a well-respected Philadelphia family, he developed an interest in medicine at an early age. His uncle, George McClellan, was one of the founders of Brinton's alma mater, Jefferson Medical College, one of the premier institutions in the city. By the time he was twenty-four, Brinton was a lecturer of operative surgery at Jefferson and a fellow at the exclusive College of Physicians of Philadelphia. Though esteemed, academic accomplishments proved not enough for a man of Brinton's ambition, and when the war broke out, he took full advantage of the opportunities it afforded. It was because of his early success, or perhaps in spite of it, that he resigned his estimable position at Jefferson Medical to enter the service of the Union Army in 1861. "Like the rest of the men my age, I soon began to feel restless at home." Brinton became convinced that his skills would be better utilized in service to his country than the lecture hall. "I felt I was not doing my full duty; that home was now no place for me." 2 Soon after, he packed his medical equipment and applied for the medical service exam.

Brinton's military accomplishment mirrored those of his time in Philadelphia. Determined to enter the Corps of Brigade Surgeons, unofficially known as "surgeons of volunteers," he finished fourth in the country on his written entrance exams and received a commission as a brigade surgeon shortly thereafter. ${ }^{3}$ Brinton quickly made a name for

\footnotetext{
${ }^{2}$ John H. Brinton, Personal Memoirs of John H. Brinton: Civil War Soldier, 1861-1865, ed. John S Haller Jr (Carbondale: Southern Illinois University Press, 1996), 17.

${ }^{3}$ Ira Rutkow, review of John H Brinton Personal Memoirs: Civil War Surgeon, 1861-1865. Bulletin of the History of Medicine 71 (1997): 534-535.
} 
himself as a skilled surgeon while serving under General Ulysses S. Grant and was soon in charge of overseeing the transformation of buildings into temporary hospitals. His performance in Grant's field hospitals earned him a reputation as a courageous and talented surgeon and he soon gained the attention of William Alexander Hammond, Surgeon General of the United States Army. After participating in several campaigns, he was assigned to the Office of the Surgeon General in Washington, D.C. ${ }^{4}$ It was here that he found himself in close association with Abraham Lincoln, "whom he was presented to [....] on official occasions." On the day of his most recent surgery, Brinton felt particularly pleased with the experimental technique he used for the shoulder joint amputation he just completed, an operation that typically carried a thirty percent fatality rate. $^{5}$ At the conclusion of the operation, a young surgeon, who had watched the amputation, enthusiastically congratulated Brinton on the procedure. The praise caught the attention of Lincoln who happened to be touring the hospital that day. Overhearing the accolades, Lincoln approached Brinton slowly from behind and solemnly asked, "But what about the soldier?"

The Civil War is known for the overwhelming devastation it caused during its four-year tenure. New research suggests that from 1861-1865 there were over 750,000 casualties, the modern day equivalent of seven to eight million Americans. ${ }^{7}$ In addition

\footnotetext{
${ }^{4}$ His impressive resume did not end in Washington. While in D.C. he established the Army Medical Museum. In 1864 he became the Superintendent and Director of General Hospitals in Nashville, Tennessee. After the war he planned and directed the compilation of the Medical and Surgical History of the War of the Rebellion while serving as Professor of the Practice of Surgery and Clinical Surgery at Jefferson Medical College. He also served on the board of the College of Physicians of Philadelphia and served a role in the Mütter Museum.

${ }^{5}$ Amputations at the shoulder joint were the most fatal out of all the amputations of the upper extremities.

${ }^{6}$ John H. Brinton, Memoirs, 265.

7 J. David Hacker, "A Consensus Based Count of the Civil War Dead," Civil War History, 57 (December 2011): 307-348. This same article suggests that numbers could have been as high as 850,000 . Though
} 
to these deaths the war produced approximately 350,000 permanently disabled bodies, a number that only increased in the post war years as the effects of old wounds and disease took their toll on aging veterans. As these numbers attest, the war had a dramatic impact on the destruction of American bodies. Historian Drew Gilpin Faust noted that, "The war's staggering human cost demanded a new sense of national identity, one designed to ensure that lives had been sacrificed for appropriately lofty ends." Few can argue that the loss of over two percent of the entire American population had a dramatic, if not revolutionary, impact on the country's relationship with death. The narrative of lost soldiers was tragic and heroic, they served as punishment for the sins of slavery and illustrative of the nation's redemption. Death, in effect, provided a symbolic icon for a country in chaos. The symbolism attached to the dead remained in flux; "[the] dead became what their survivors chose to make of them.",

Given the period's fixation on human demise it is no surprise that the nation altered the way it viewed the vessel of death. After all, death is not possible without a body. And it was the bodies of Civil War soldiers that laid the foundations for "the modern American union." Even still, these bodies did more than illustrate the wreckage of war. They provided the means for beneficial advancements to both individuals and the nation. Just as survivors chose to make what they wanted of the dead, so too did medical practitioners find similar uses for the body. A close inspection of the relationship between the surgeons and bodies reveals that there existed a distinct difference between "the soldier" and his individual parts. The two could truly be separated both literally and

scholars, including Hacker himself, agrees that an exact count of those who died in the war can never be known.

${ }^{8}$ Drew Gilpin Faust, This Republic of Suffering: Death and the American Civil War. (Vintage Books: New York City, 2008).

${ }^{9}$ Faust. 
figuratively. The dissection of a soldier and his body lay at the very root of a surgeon's ability to perform his craft. The surgical "art," as it was commonly called, freed practitioners from the sentimental and romantic elements of war. As John Brinton's anecdote suggests, non-medical professionals and surgeons often came into conflict over the appropriate way to view wounded men.

While the profusion of dead and wounded bodies was tragic, it also provided the basis for the rapid growth of American medicine. In the antebellum period the medical profession was largely seen as crude and inchoate when compared to Europe. American medicine faced a number of obstacles preventing it from advancing on the same scale as France or Britain. Disorganized infrastructure, an emphasis on "home" healing, a lack of specialization, disreputable medical training facilities, lack of licensing, intra-profession quibbling, competition, western expansion (frontierism), public disdain, and an inherent emphasis on republicanism and independence, all served to stymie medical growth in the United States. Amongst all these roadblocks, however, there was one major impediment to medical advancement; a lack of bodies.

It is an understatement to say that the field of American medicine owes much to the Civil War. The millions of wounds caused by the war ensured that an excess of bodies would be available to learn from, should the Army Medical Corps choose to take advantage. And take advantage it did; during the war the United States boasted that it had the largest body of proficient medical workers in the world. In addition to educated surgeons and doctors, the war ushered forth a unified medical profession, a wellrespected hospital system, a government sponsored anatomical museum, and enough medical information to publish the Medical and Surgical History of the War of the 
Rebellion, a six volume series that detailed tens of thousands of surgical cases and diseases. Cities like Philadelphia and Washington D.C. began to rival renowned medical meccas like Paris and London. By the end of the century, the United States was one of the leaders in medical research and education. The war did much more than transform the medical profession itself, it forced the public to revaluate the cultural taboo of bodily dissection, study and experimentation for the sake of medical advances. This chapter argues that the wholesale destruction of human bodies had a generative effect on the field of American medicine. In so doing, the war not only modified the profession itself but also redefined well-established assumptions regarding the human body.

\section{Fractious Medicine: The Antebellum Period}

During the early American period, the U.S. medical field was in its infancy. While medical practitioners in Paris and London developed new technologies, published research articles, and advanced innovative medical theories; their American counterparts languished in a dormant state of uninspired banality. By comparison, surgeons in the states were considered unsophisticated in their knowledge and downright crude in their application of treatment. Like most Americans who studied abroad, one surgeon believed that, "one Frenchman [was] equal to a dozen Americans." In fact, European trained surgeons often taunted American physicians with their pretentious manner of boasting the superiority of French and British medical institutions. One can hardly blame European trained surgeons for their gloating, as Harvard Medical School failed to incorporate the stethoscope into its teaching techniques until thirty years after its invention. France, long considered the epicenter of medical thought, developed a widespread hospital system in 
almost all of its major cities beginning in the 1750s; Britain adopted a similar system a few decades later. However, nearly a century after the inception of the hospital system, the United States still did not have one significant general hospital in any of its major cities. $^{10}$

Medical practice in the United States was structurally and socially different than its rivals in Europe. While Europe's medical field mirrored its aristocratic society, the U.S. system was more egalitarian in nature. For example, England developed a highly stratified, yet unified, system of guilds that maintained national authority. These guilds controlled the process by which the three branches of medicine - physicians, surgeons, and apothecaries - developed in England. Training, licensing, and research were all subject to parameters set by these guilds. The benefit of this unified national system promoted professional development, while simultaneously limiting egregious forms of quackery. The American system, like Britain's, sought unity, though struggled to create an authoritative medical voice due to social adherence to the ideals of independence. During the colonial period, American physicians also held numerous non-medical positions. Cotton Mather, most known for his role in the Salem witch trials of the seventeenth-century, was a Puritan minister, moral and political leader, pamphleteer, author, botanist, and doctor. In the southern colonies it was not uncommon for planters to take on the role of community leader, lawyer, and medical practitioner in their region. While the composition of the colonial medical system eventually changed, it was not

\footnotetext{
${ }^{10}$ Howard A. Kelly and Walter L. Burrage, American Medical Biographies (Baltimore: The Norman, Remington Company 1920), 844.; Rosemary Stevens. American Medicine and the Public Interest (New Haven: Yale University Press. 1971. Stevens argues throughout her work that the U.S. hospital system did not develop until the late nineteenth century, however even a cursory look at the medical field during the Civil War demonstrates how hospitals were an integral part of the war.
} 
until the post-Revolutionary period that America could boast an identifiable, yet disparate, system of medical training. ${ }^{11}$

The democratic ideals that fueled Americans at the close of the eighteenth century influenced the nation's erratic approach to medicine. Egalitarianism and independence prompted many states to determine their own system of regulation. The state of New York adopted a governmental licensing system as early as 1760; the Connecticut Medical Society, an independent organization free from government control, had the power to bestow both a license to practice as well as medical degrees; Massachusetts, however, divided its regulation between two self-governing entities in 1803, the Harvard Medical School awarded degrees while the Massachusetts Medical Society issued licenses, only one of which was necessary to practice medicine. Commenting on the lack of authoritative oversight in the post Revolutionary period, Oliver Wendell Holmes remarked the medical leaders of the time, ..."could not help feeling as if Nature had been a good deal shaken by the Declaration of Independence, and that American art was getting to be rather too much for her, - especially as illustrated in his own practice." 12

Diverse medical training created even more disunity and rivalry among physicians. Those interested in practicing medicine had no shortage of options available to them. University medical schools like Harvard, Yale, Dartmouth, and Jefferson were the most esteemed centers for learning. However, those uninterested, or unable, to attend a university could simply enroll in one of the numerous proprietary schools sprouting up around the country. In 1800 there were four of these proprietary charter schools, but by

\footnotetext{
${ }^{11}$ There were multiple branches of medical practitioners in England. The barber-surgeon, city physician, and the country-surgeon, and the apothecary, each catered to a different class of patient. Rosemary Stevens, 12.

${ }^{12}$ Oliver Wendell Holmes, "Currents and Counter-Currents in Medical Science" (1860), in collected papers of the same title. Cambridge, Mass. 1861, pp 11, 26.
} 
1835 there were as many as forty-four. All told, over four hundred proprietary schools were founded in the nineteenth century, most of which failed during the Civil War. Despite their brevity they had a dramatic impact on medical education and practice during the nineteenth century. In the face of this unorthodox competition, university schools aligned themselves more closely with medical developments in Europe. Paradoxically, proprietary schools focused on supplanting the apprenticeship system still available in some states. Thus, the typical medical graduate in the antebellum period was the product of either an apprenticeship or of a completely autonomous teaching institution. ${ }^{13}$

The training that these schools offered, at times, was a source of irritation for those seeking a rigorous medical education. Andrew Boardman, who attended Geneva Medical College in central New York in the 1840s, complained about his medical courses. The college's circular promised that the "anatomical class should have a full supply of subjects," an enticing prospect given the severe lack of anatomical specimens in the antebellum period. To his disappointment Boardman soon found that "not a single subject was provided for dissection during the whole session" despite having paid a fee of $\$ 40.00$ per subject at the beginning of the term. Boardman went on to list a litany of complaints against the medical college going so far as to detail the failed promises of the college. The circular for the school claimed to offer courses on medical jurisprudence and physiology, though provided neither. Even the facilities failed to live up to expectations. The college, which promised first-hand clinical instruction in a hospital, was actually an old shoe store and during the whole session "contained not one medical patient and only one surgical patient." Boardman's time in the old shoe store was in full

\footnotetext{
${ }^{13}$ Rosemary Stevens, 24-25.
} 
competition with the local population who came to the hospital "attracted by the reputation of the surgical professor, however, many patients came in from the surrounding country, on whom operations were performed for the class." He went on to note that the college offered "no means of acquiring practical skill and have been afforded no tests of practical skill having been applied." Boardman was so indignant at the school for their "failed lessons" that he refused the obligatory diploma handed out to its graduates. ${ }^{14}$

Due to the incongruent nature of medical authorization, standardization in the field became almost impossible. Quality control became a serious detraction from professionalization and a stain on the reputation of the American medical field. The public held little confidence in the abilities of doctors, and often viewed them as poorly educated, overly competitive, and full of avarice. Many complained that physicians were more concerned with fees and pushing out competition than they were with ministering aid to the sick. When a group of six physicians successfully formed a cartel on medical licensing in New York City in 1833, citizens took a hostile tone. They charged that these physicians sought to create their own laws and regulations based on the fictitious notion of fighting quackery, when in fact they were looking to monopolize the field. Instead of raising their own standards of medical practice, they argued, the cartel was more interested in falsely charging possible competitors with fraudulence. The group was "ostensibly for the protection of the sick, and the encouragement of medical science, but in truth, for the pecuniary benefit of a few aspiring physicians. ${ }^{15}$ English satirists poked

\footnotetext{
${ }^{14}$ Andrew Boardman, "Essays on the Means of Improving Medical Education and Elevating Medical Character," in Medical America in the Nineteenth Century: Readings from Literature ed. Gert H. Brieger (Johns Hopkins Press: Baltimore), 26-27.

${ }^{15}$ John F Gray. The Policy of Chartering Colleges of Medicine (New York, 1833).
} 
fun at the acquisitive nature of Americans pointing out the inferior status of their medical education. Edward Baynard's poem "Doctor's, Decade, Or the Utensils of His Trade," revealed these sentiments.

In Ten Words the whole Art is comprised For some of the Ten are always advised... These few Evacuations Cure all the Doctor's Patients.

What more they advance Is all done by chance; So as to a Cure There's none to be sure.

Most other Specificks Have no visible Effects, But the getting of Fees For a Promise of Ease... ${ }^{16}$

Physicians themselves, took any opportunity they could to denounce their fellow colleagues. One prominent doctor noted that "not one man" in the United States was doing significant medical research. ${ }^{17}$ In 1852, the New Englander continued this assault on American medicine, "in the whole vast compass of medical literature, there can not be found an equal number of pages containing a greater amount and variety of utter nonsense and unqualified absurdity."18 The lack of "social connection" served to divide the field. " ${ }^{19}$ "Few Physicians among us are eminent for their skill. Quacks abound like locusts in Egypt... This is to be wondered at as the profession is under no kind of Regulation. Any man at his pleasure sets up for Physician, Apothecary, and Chirurgen

\footnotetext{
${ }^{16}$ Edward Baynard, Health, A Poem $7^{\text {th }}$, ed London 1742, 37-39.

${ }^{17}$ Richard Harrison Shryock, Medicine and Society in America, 1660-1860 (New York: New York University Press, 1960) 117. Quoted.

${ }^{18}$ W. Hooker, "The Present Mental Attitude and Tendencies of the Medical Profession," New Englander, X (1852), 548-568.

${ }^{19}$ Nathan S. Davis. History of the American Medical Association from its Organization up to January, 1855 (Philadelphia, 1855), 19.
} 
[surgeon]. ${ }^{20}$ Self-serving competition continued to generate rifts rather than collaboration between medical institutions and practitioners. Philadelphia, long considered the premier city for medical education in the United States, was itself fraught with rivalry. Competition between the University of Pennsylvania and Jefferson Medical College pitted lecturers against one another. Esteemed surgeons from both schools, George McClellan and William Gibson, were known to feud publically and in front of lecture attendees. In one amusing anecdote, Gibson openly accused McClellan of falsifying the medical operation of the removal of a large salivary gland (the parotid gland) in the back of the mouth. Gibson argued that such an operation was impossible in the early nineteenth-century. Soon after, Gibson prepared to perform his own operation of a tumor near the parotid gland. In dramatic fashion he invited his rival to witness the surgery to prove that the removal of the gland itself was unfeasible. After the success Gibson turned toward the audience and stated, "Gentleman, I have performed what is generally called extirpation of the gland." Keeping an eye on McClellan he then announced, "However, the mass I removed is only a tumor overlaying the gland, not the gland itself." At this point McClellan stood and replied, "Gentleman, my distinguished friend has extirpated the parotid gland, but, unfortunately, doesn't know it." Years later Gibson reflected that this period of American medicine would be remembered "for rivalry marked with jealousy and unfairness. ${ }^{.21}$

Competition was so rampant that sectarian differences stymied all communication between some physicians, contributing to the deterioration of the health of the general public. "The history of medical schools in the nineteenth century is a tale of schisms,

\footnotetext{
${ }^{20}$ William Smith. History of the province of New York (London, 1757), 212.

${ }^{21}$ Samuel D Gross, Autobiography of Samuel D. Gross: With Sketches of his Contemporaries. Vol. II. (Philadelphia: George Barrie Publishing, 1873), 328.
} 
conspiracies, and coups. ${ }^{22}$ Even Benjamin Rush, one of the nation's most respected physicians, commented on the contention, "A Mahometan and a Jew, might as well attempt to worship the Supreme Being in the same temple, and through the medium of the same ceremonies, as two physicians of opposite principles and practices, attempt to confer about the life of the same patient." ${ }^{, 23}$ Even professors from the same school competed with one another. In 1838, the board of trustees at Jefferson Medical College became so intolerant of its faculty for refusing to work collaboratively that they fired all the chaired professors, including one of its founding members.

The poor opinion of American medicine only worsened during the democratization period of 1830 s and 1840 s when a number of states began lifting licensing requirements. America's Jacksonian adherence to the principals of egalitarianism made a decided effort to forsake elitism in the medical field by abandoning regulatory state laws. This was on par with a nationwide attack on elitism at all levels of American society. In 1838 Congress lifted restrictions on unlicensed medical practitioners in Washington D.C., followed shortly thereafter by Maine, Connecticut, and Massachusetts. Throughout Jackson's presidency, states across the U.S. repealed all medical licensing. Between 1833 and 1848, Ohio, Mississippi, Maryland, Michigan, and Texas all abolished regulatory laws. Going even further, New York and South Carolina actually removed penalties for practicing medicine without a license. By 1845 there were ten states in the Union that provided no guidelines on medical standards or licensing. "Just as England was preparing to entrench medical licensing by Act of Parliament, the

\footnotetext{
${ }^{22}$ Paul Starr, Social Transformation of American Medicine: The Rise of a Sovereign Profession and the making of a Vast Industry (New York: Basic Books Publishing, 1982), 93.

${ }^{23}$ Starr, 93.
} 
United States seemed to accept the market as the sole criterion of professional skill., ${ }^{24}$ While a number of medical societies sought to raise the standards of medical practice, they were usually countered by a defense of "laissez-faire competition and an attack on the motivations of medical men." 25 One New York senator epitomized the fear surrounding medical monopolies and in his bill to repeal licensing requirements he noted, "A people accustomed to governing themselves, and boasting of their intelligence, are impatient of restraint. They want no protection but freedom of inquiry and freedom of action." ${ }^{26}$ Americans, in their passion for independence, had the right to choose between the trained and the untrained doctor. In the words of historian Richard Shryrock, "Thus did Jacksonian Democrats proclaim their inalienable rights to life, liberty, and quackery.,27

The egalitarian approach of the Jacksonian period meant that the practice of medicine was the province of all citizens. Only the wealthiest of families could afford to call upon a doctor accredited from a university medical school, therefore the idea of visiting an orthodox physician seemed unattainable and overly urbane to most families. Additionally, much of the general public continued to view well-trained doctors with the same sense of suspicion that they reserved for any group or organization that threatened to accumulate too much power. What could be more powerful than to demand exorbitant fees for the treatment of loved ones? The amalgamation of republicanism and distrust prompted many Americans to look for an alternative form of medicine. Nobody in the early nineteenth century epitomized the virtues of domestic healing more than Samuel

\footnotetext{
${ }^{24}$ Stevens, 27.

${ }^{25}$ Shryock, Medicine and Society 20, 149.

${ }^{26}$ C.B. Coventry, "History of Medical Legislation in the State of New York," N.Y. Journal of Medicine, IV (1845), 160.

${ }^{27}$ Shryock, Medicine and Society 149.
} 
Thomson. After nearly losing his wife to conventional practices, he devoted his life to devising a system that would unshackle the average American from medical despotism. As a self-taught herbalist and botanist, Thomson's alternative methods swept through the U.S. reaching its height in the antebellum period. The appeal of Thomsonian Medicine was that anyone one could learn how to apply his methods, and his motto "everyman his own physician," inspired many to adopt his system. At a time when physicians were coming under criticism for their devotion to bloodletting, Thomson's remedies, which included steam baths and cayenne pepper, seemed innocuous by comparison, if not luxuriously soothing. "Much of what is at this day called, medicine," Thomson wrote, "is deadly poison." Central to his brand of healing was a means to tear down the aristocratic obscurity of medicine. "Let the mystery be stripped of all pretence $[s i c]]^{\text {"28 }}$ To promote his alternative medicines Thomson published numerous books, journals, recipes and herbal supplies, which he distributed from a warehouse. Any family interested in his methods of self-teaching could purchase a start up pack for about twenty dollars. "The expenses will be small and much better than to employ a doctor, and have his extravagant bill to pay. ${ }^{29}$ By 1840 he sold over 100,000 patents to the American public. ${ }^{30}$ The popularity of Thomsonian Medicine underscored the nation's growing unease with the high cost of medical care. As one manual argued, "the benefits of Medicine as a trade will ever be confined to those who are able to pay for them; and of course, the far greater part of mankind will be every where deprived of them. ${ }^{, 31}$

\footnotetext{
${ }^{28}$ Samuel Thomson, Thomsonian Recorder 1 (December 15, 1832), 123.

${ }^{29}$ Samuel Thomson, New Guide to Health; or Botanic Family Physician, 1822.

${ }^{30}$ Rosemary Stevens, 21.

${ }^{31}$ Abbot, Simon. Southern Botanic, iii. Quoted. Elizabeth Barbnaby Keeney. "Unless Powerful Sick: Domestic Medicine in the Old South," in Science and Medicine in the Old South, ed. Ronald Numbers and Todd L. Savitt. (Baton Rouge: Louisiana State University Press, 1989), 284.
} 
Even in the south a focus on the do-it-yourself medical approach existed wherein health and medicine affected the lives of nearly everyone just as in the north. Southerners fretted over seasonal diseases that could decimate entire regions. Cholera, typhoid, and yellow fever were common endemics that swept through large cities and small towns alike. Yeoman and tenant farmers struggled with keeping family members free from illness, while planters worried about maintaining a healthy plantation.

In his classic 1930 essay, noted medical historian Richard Harrison Shryock argued that the south viewed itself as medically distinctive based on the varied working conditions, environmental conditions, and the pervasive influence of slavery. These items did more to shape the southern ideals of medicine and public health than monopolistic fears. ${ }^{32}$ Trained medical doctors continued to play a role in the overall health of men and women in the south. Typically these physicians received their education in Europe or in major northern cities like Philadelphia or Boston. However, like the general public in the north, yeoman and tenant farmers could rarely afford the cost of orthodox doctors. Not only were patients charged the regular fee for medical services, many doctors also added fees for travelling expenses. Due to the south's agrarian system it was difficult for country doctors to minister aid to every person in need of medical treatment in a particular region. The duration of travel occupied so much of a doctor's day that it placed constraints on the number of patients he could accept, as well as his income. To make up lost finances, doctors in places such as Alabama and Georgia charged as much as $\$ 1$ per mile during the day and $\$ 2$ per mile at night. The high cost of

\footnotetext{
${ }^{32}$ Ronald Numbers and Todd Savitt, ed. Science and Medicine in the Old South, 148. Richard Harrison Shryock, Medical Practice in the Old South," South Atlantic Quarterly, 24 (1930), reprinted in Shryock, Medicine in America: Historical Essays (Baltimore, 1966), 49-70.
} 
treatment in the rural south made healthcare prohibitive for most farmers. ${ }^{33}$ Thomsonian Medicine, however, provided an outlet for families in financial hardship in need of medical attention.

The do-it-yourself form of medicine struck a chord with southerners who found virtue in the intuitive wisdom and the anti-intellectualism of Thomson's methods. By 1835, leading botanists claimed that over twenty thousand Georgians were using Thomsonian Medicine. In that same year Mississippi's governor, Hiram Runnels, proclaimed that half of the state's residents received Thomsonian treatments by both domestic and professional practitioners. In the spring of 1834, John Walker, a Virginian farmer, spent $\$ 23.871 / 2$ on manuals and recipes from a Thomsonian agent, which allowed him to produce his own medicines for a lifetime. The price was less than half of what slaveholders could expect to pay for professional care in a year. ${ }^{34}$ Another planter believed so strongly in domestic medicine that he proclaimed calling for a doctor was synonymous with giving up on a patient's recovery, which led to complaints by trained physicians about the state of medical practice in the south. ${ }^{35}$ Isaac Wright went one step further in his Family Medicine manual, arguing that his brand of medicine would "enable the people to distinguish the man of practical science and wisdom from the ignorant pretender and the assuming quack." ${ }^{36}$ In addition to detailing medical treatments for everything from a minor cough to rheumatism, he published methods for curing gangrenous limbs without the act of amputation. His cure consisted of applying a

\footnotetext{
${ }^{33}$ Starr, 67-69.

${ }^{34}$ Elizabeth Barbnaby Keeney, 284.

${ }^{35}$ Ralph Betts Flanders, Plantation Slavery in Georgia Chapel Hill, 1933. 164, quoted in Elizabeth Barbnaby Keeney "Domestic Medicine in the Old South," 286.

${ }^{36}$ Isaac Wright, Family Medicine, or System of Domestic Practice. (Henderson, Johnson \& Co: Madisonville Tennessee, 1833), ix.
} 
"poultice of sweet milk and flour to the leg until mortification took place," then applied hot steam laced with "wool, bacon rinds, and life everlasting" to the affected skin "all the subsequent night and into the morning." Once the skin was adequately steamed one could "slough off" the mortified flesh and take "in pieces as thick as a man's hand until the whole of the dead \& bruised parts came off, which was nearly all the flesh from the knee to the ankle." At this point the patient should be made to drink "plentifully of dog wood tea" and have his leg stretched out straight "so that it might be as long as the other when the new bone was formed." ${ }^{37}$ Fixing broken bones was so common that one planter asserted "Any person of common sense knows how the bones ought to be when not displaced; and by exercising a little mechanical ingenuity after the muscles are relaxed he will be able to return them to their proper situation. ${ }^{38}$

Egalitarian medicine was so rampant in the south that even surgical cases were not viewed as an obstacle to a capable planter. Publishers realized that laymen might have to perform operations if a trained surgeon was not available, as in the case of one plantation mistress, who according to historian Catherine Clinton "surgically [removed] a feather from an infant's throat." ${ }^{39}$ Some manuals even provided instructions for performing operations in the home without the guidance of a medically trained doctor. A.G. Goodlett chastised laymen who called for doctors arguing, "any man, unless he is an idiot or an absolute fool," can successfully amputate a limb. ${ }^{40}$

\footnotetext{
${ }^{37}$ Wright, 239. Unfortunately, Wright's gangrenous "treatment" actually increased the possibility of amputation and fatality. The warm sweet milk poultice created a perfect breeding ground for bacteria.

${ }^{38}$ Abbott, Southern Botanic, 196, v. quoted in Elizabeth Barbnaby Keeney, "Domestic Medicine in the Old South."

${ }^{39}$ Catherine Clinton, Plantation Mistress: Women's World in the Old South New York, 1982. quoted in Elizabeth Barbnaby Keeney, "Domestic Medicine in the Old South," 287.

${ }^{40}$ Blake, "From Buchan to Fishbein: The Literature of Domestic Medicine," in Guenter B. Risse, Ronald Numbers, and Judith Walzer Leavitt (eds), Medicine Without Doctors: Home Health Care in American
} 
Unlike today, the field of medicine in the prewar period did not promise social or professional prestige. Though the status of physicians was not diminutive, one historian classified it as "insecure and ambiguous." ${ }^{41}$ Doctoring was mainly a "loner" profession, and did not incur the advantages of widespread collaboration. ${ }^{42}$ The practice of medicine was subject to hierarchical inequalities that mirrored class structure, which only fueled internal dissent. While wealthy families could afford to hire physicians educated in Europe, low-income families were forced to hire poorly trained practitioners or utilize some form of domestic medicine. In the middle resided the great majority of doctors who, "had served an apprenticeship, and perhaps taken a course of lectures or a two-term medical degree, but who had little general education.. ${ }^{43}$ In order to overcome the dire status of the profession they would need to find a way to elevate the reputation of those practitioners in the middle and lower end of the spectrum.

Added to the social uncertainties, aspiring physicians faced familial frustration over their chosen vocation. J. Marion Sims, one of the leading surgeons and considered the father of modern gynecology, returned home after obtaining his degree from Jefferson Medical College. ${ }^{44}$ His father hoped that he would pursue a career in law and upon discovering that Sims continued to practice medicine he remarked, "If I had known this I certainly would not have sent you to college.... it is a profession for which I have the utmost contempt. There is no science in it. There is no honor to be achieved in it; no

\footnotetext{
History (New York, 1977)," 25. Quoted in Elizabeth Barbnaby Keeney, "Domestic Medicine in the Old South.”

Keeney "Domestic Medicine in the Old South," 287

${ }^{41}$ Starr, 81.

${ }^{42}$ Rosemary Stevens, 24.

${ }^{43}$ Starr, 82.

${ }^{44}$ Sims was hailed as a medical innovator for his successful surgical techniques on a condition known as vesicovaginal fistula, a urinary affliction caused by damage to the vaginal wall from violent rape or trauma. His reputation suffered considerably when it was discovered that he experimented on 14 enslaved women without the use of anesthetics; one woman was operated upon over 30 times.
} 
reputation to be made." Silas Weir Mitchell experienced a similar reaction from his father, who was a surgeon himself. Shortly after college, Mitchell's capricious nature moved him into a number of different career paths that included commerce, chemical manufacturing, and toxicology. In his memoirs he noted, "After a while my father more distinctly insisted on a choice, and I at last decided to be a doctor, much to his disgust."45 He eventually specialized in neurology; his work was so ubiquitous in the late nineteenth century that Sigmund Freud credited Mitchell's theories of electrotherapy in his own work. $^{46}$ To quote one medical journal, when a talented and ambitious young man set his sights on the practice of medicine, "the feeling among the majority of his cultivated friends is that he has thrown himself away."47

Samuel D. Gross, one of the most revered surgeons of the period, summed up the state of medicine in the prewar period.

\begin{abstract}
The medical profession $[\ldots .$.$] at the period in question was in a decidedly mediocre$ condition, without science, without learning, without progress, and apparently without ambition. Every man seemed to live in and for himself. Hardly any two could be found willing to meet each other in consultation. Jealousy and ill-feeling were the order of the day. They each had their own little clique or faction. But one thing all were agreed: they all bled, all gave emetics, all purged, all starved their patients. They were all real Sangrados, ${ }^{48}$ mowing down alike the infant, the youth, the adult, and the old man....Very few of them ever read a medical book; and, as to social intercourse, that is of course wholly out of the question under the circumstances. ${ }^{49}$
\end{abstract}

On the eve of war the medical field was in disarray. Inter-rivalry, a lack of authority over medical treatments, diverse educational standards, suspicion by the general

\footnotetext{
${ }^{45}$ Starr, 82.

${ }^{46}$ Silas Weir Mitchell also authored the fictional account, "The Case of George Dedlow," a story about a quadruple amputee from the Civil War. He coined the term "phantom limb" during one of his studies of amputee soldiers.

${ }^{47}$ Editorial, “American vs. European Medical Science,” Medical Record 4 (May 15, 1869), 133.

${ }^{48}$ Sangrado is a term used to describe someone who pretends to be knowledgeable in medicine. A quack.

${ }^{49}$ Gross is the august figure in Thomas Eakins' "The Gross Clinic" portrait, which currently hangs in Jefferson Medical School. There is also a bronze statue of him in Philadelphia. Samuel D Gross, Autobiography of Samuel D. Gross: With Sketches of his Contemporaries. Volume. II (Philadelphia: George Barrie Publishing, 1873), 56-57.
} 
public, poor professional oversight, and a lack of support, left a pall over the field. However, the future of American medicine was not completely dire. As Rosemarie Stevens demonstrated, it was from this "apparently poor but potentially fertile ground that the future structure of medicine....was to emerge." The plethora of schools, societies, treatment styles, and licensing debates, was a testament to the public interest in medicine. ${ }^{50}$ When war broke out the infrastructure for medical innovation was already in place.

A number of notable events occurred in the two decades prior to the war that offered hope to a fragmented profession. In 1846, William T.G. Morton and John Collins Warren gave the first public demonstration of an anesthetic in use. Using a mixture of sulphuric ether mixed with air, they surgically removed a small tumor from the neck of a patient. The patient made no motion as the scalpel sliced into his flesh, nor did he rouse when the surgeon used a suture needle to sew his wound closed. When Warren completed the surgery he turned to the slack-jawed crowd and said, "Gentleman, this is no humbug." ${ }^{51}$ The event was a historic success, news of the painless procedure, while minor, swept across the United States and soon other surgeons experimented with the anesthetic in more complex operations. Henry J. Bigelow used the ether mixture to successfully eliminate all pain during a full amputation at the thigh, one of the most excruciating and fatal operations during the time period. In December of that same year Thomas Mütter, who helped lay the foundations for American plastic surgery, became the first surgeon in Philadelphia to anesthetize a patient. Unfortunately for Mütter, the

\footnotetext{
${ }^{50}$ Rosemary Stevens, 26.

51 John Collins Warren went on to become the first dean of Harvard Medical School and president of the American Medical Association. He was also the founder of the New England Journal of Medicine.
} 
application of ether continued to be highly controversial and he faced strong resistance from the more conservative physicians in the city.

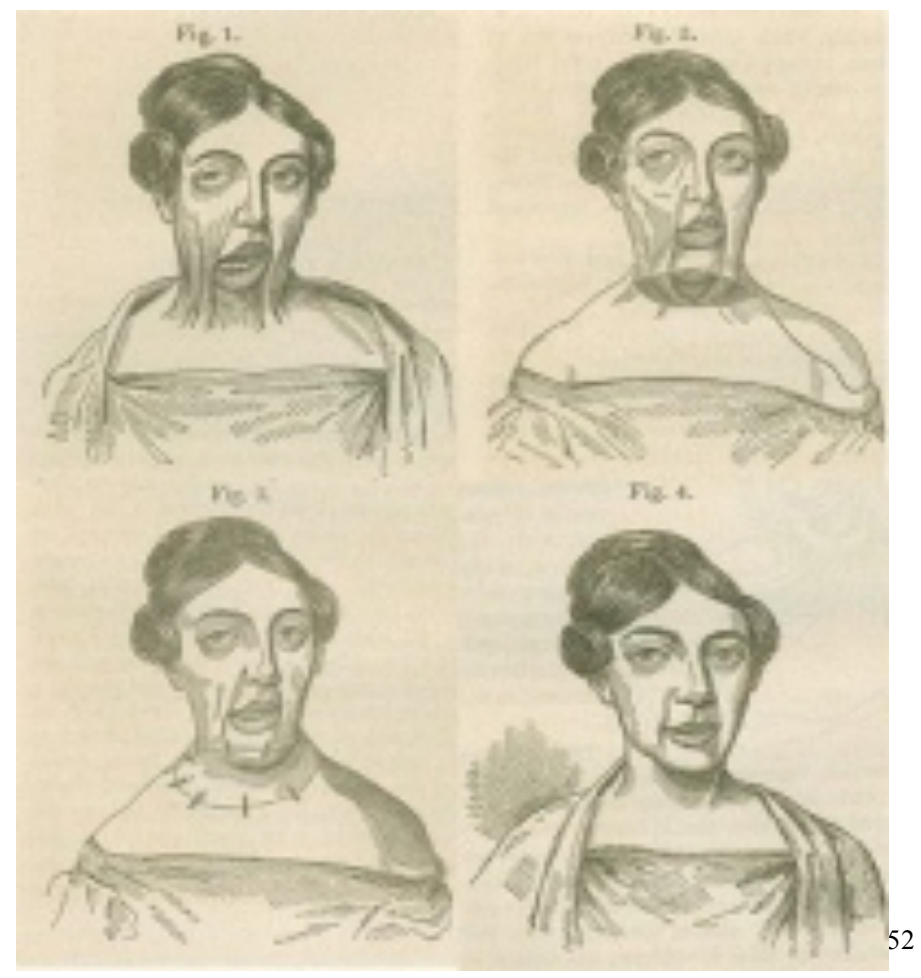

Shortly after the advent of anesthesia, the medical profession sought ways to overcome the problems plaguing the field. Over two hundred and fifty delegates from twenty-eight states launched the first official convention of the American Medical Association (AMA) in 1847. The founding meeting promoted a national standardization of medical education and practice as well as the application of a "code of ethics" for physicians. While the nascent group did not hold any real power in the antebellum period, by the end of the century, the AMA represented the best of American medical

\footnotetext{
${ }^{52}$ During the antebellum period it was not uncommon for women's constrictive clothing to catch fire from getting too close to cooking fires. These women suffered severe disfigurement and public shame. Dr. Thomas Mütter devised a treatment by which skin from the back was grafted to the neck and jaw. Many of these operations were performed prior to anesthetics. The "Mütter Flap" is one of the earliest successful skin grafts and its techniques are still used today.
} 
standards. Additionally, by 1860 American physicians adopted so-called Paris Clinic methods of diagnosis in increasing numbers. While still new to most Americans, this method prompted doctors to examine the body of their patients in an effort to distinguish disease or injury. Also known as the French School of thought, this system taught physicians to compare similar bodily conditions with previous cases while incorporating modern medical equipment. This system was a progression beyond the centuries old "Hippocratic School," which consisted of passive observation rather than active engagement. Though fewer than 1,000 American doctors studied these innovative clinical methods in France during the antebellum period, they returned home with the techniques and helped lay the foundation for its popularization. The Paris Clinic was so popular among well-educated doctors that Jefferson Medical College advertised its curriculum based on clinical training, the first school in the United States to offer such a program. Students were expected to shadow physicians as they tended to patients, a revolutionary concept in early American medicine. The clinic proved to be so successful that it soon set the school apart from many of its rivals. Over time Jefferson expanded its facilities to allow surgical patients to convalesce in recuperation beds, as well as consenting to year round access for students, rather than just the months when classes were in session. ${ }^{53}$ While typical medical practitioners were still considered jack-of-alltrades, (ie. a doctor, surgeon, midwife) the field steadily, though slowly, moved toward specialization due to the influence of the Paris Clinic, a change that only hastened after the Civil War. Not only did the AMA form but, the precursor to the American Psychiatric Association had already been in place for over a decade, medical colleges

\footnotetext{
${ }^{53}$ Prior to the recuperation beds, surgical patients were sent home in carriages immediately following procedures. Cobblestone streets and unsanitary carriages often increased post-surgical complications. Surgeons then had to spend their days traveling around the city checking in on patients.
} 
offered chairs in obstetrics, divided its surgical chair into two separate positions, theory and practice, and experimented with anesthetic inhalers.

And so it was that as P.G.T. Beauregard fired upon Fort Sumter, the medical industry was embroiled in its own war. On the one end there existed a group of young doctors and surgeons intent on utilizing the latest medical advances and pushing for stronger oversight of medical education. On the other hand were conservatives and opportunists resistant to new methods of medical practice. To break the stalemate all that was necessary was an unprecedented national catastrophe.

\section{The Civil War Years: Engaging with Bodies}

In general, historians have been unwilling to draw strong links between the Civil War and the development of American medicine. The historiography of nineteenth century medicine, despite its immense value, generally downplays, or outright ignores the war's contribution to the medical field. Perhaps historians have been loath to acknowledge the potential benefit of 750,000 deaths and millions of war related injuries to America's medical prowess. Prior to the recent interest in medical history, studies tended to gloss over or completely ignore to the Civil War years. By and large, early literature on the role of medicine during the war "lacks almost any analysis" and assumes that the practice of medicine was an unmitigated disaster. ${ }^{54}$ Popular misconceptions about the "butchery" of physicians, the lack of anesthesia during amputations, and the poor general quality of medical care still resonates prominently. The advent of generative-effect studies, however, challenges scholars to rethink the war's most

\footnotetext{
${ }^{54}$ Shauna Devine, Learning from the Wounded: The Civil War and the Rise of American Medical Science (Chapel Hill: University of North Carolina Press, 2014), 4.
} 
destructive consequences. It was not until recently that scholars began to analyze the overall importance of the war's impact on American medicine in the nineteenth century. Shauna Devine's recent study, for example, argues that the science of medicine "took off' during the war years, in large part because of the acquisition and study of anatomical specimens from the battlefield. The Army Medical Museum prompted medical practitioners to detail treatment techniques while also requiring them to contribute to the growing collection of medical data. Margaret Humphreys offers a compelling account of the organized relief efforts of both the government and women on the home front, arguing that each played a prominent role in combating the effects of disease and malnutrition. The nation's focus on public health helped to ameliorate the privations suffered by soldiers. ${ }^{55}$

Recent scholars, who have taken up the banner of Civil War medicine, advance our understanding of the field by situating their work within the broader nineteenth century. This trend builds on the institutional developments of health, pharmacology, and professionalism, while simultaneously layering their study with an analysis of race, class, or gender. Few studies, however, take into account the vital importance of soldiers' bodies to the development of these medical trends. Thousands of voices from the Civil War era decried the surfeit of human remains. Each story that told of the piles of "arms, hand, feet and legs!" or described the "bloated, blackened...prey of worms," helped to create a context of meaning that shaped the opinions, experiences, and skill of surgeons. ${ }^{56}$

\footnotetext{
${ }^{55}$ Ibid., Margret Humphreys, Marrow of Tragedy: The Health Crisis of the American Civil War (Baltimore: Johns Hopkins University Press, 2013).

${ }^{56}$ E.H. Harris, Letters, "Fair Oaks Battle Field," "Dudley Farms," June $19^{\text {th }} 1862$.
} 
When Abraham Lincoln called for 500,000 additional troops after the loss at First Manassas, men rushed to enlist in the army. Recruiters met the mandated quota so quickly that they were forced to turn men away. Much like the army's enlistees, medical practitioners scrambled to enlist in the army. Surgeons swarmed recruitment offices, wrote letters to influential friends, and appealed to anyone who could help them enter into military service. These men signed up for many of the same reasons that soldiers did. A grand sense of adventure, the opportunity to improve one's reputation, an obligatory sense of duty, and pressure from community members all played a role in getting doctors, and especially surgeons, to volunteer. Perhaps the most powerful motivator, however, was the sudden access to bodies. During the antebellum period Americans held strict opinions about the sanctity of the human body. Medical educators consistently struggled to find enough cadavers for training and experimentation. The paucity of human forms is one reason why wealthy medical students looked abroad for medical training. Most states only allowed executed criminals to be dissected and unfortunately for medical colleges there were not enough of those around. Andrew Boardman complained that only one test body, "and a very poor one," was available for demonstration during the entire anatomical course at Geneva College. ${ }^{57}$ The scarcity of cadavers explains the rise in grave robbing in the decades leading up to the war. The public feared dissection so much that several anatomy riots occurred in cities throughout the United States. Dissectors were rejected by the public and were viewed as little more

\footnotetext{
${ }^{57}$ Andrew Boardman, 26-27.
} 
than sadistic butchers. What medical education lacked most just prior to the war, was a steady supply of anatomical specimens with which to learn and experiment on. ${ }^{58}$

The war offered physicians the potential for unlimited access to human remains. The bodies of Union soldiers were dissected and studied with little oversight from superiors. Wounded soldiers became living test subjects for experimentation while photographers and journalists documented the "butchery" of surgeons at their craft. Yet, no riots occurred in any city during the war despite the so-called "mutilation" of bodies taking place on soldiers, not criminals or undesirables. In fact, the military actually collected morbid specimens from across the Union war front. Not only were soldiers' body parts amassed for collective study, but the United States government put them on display for the public. The public's acceptance of experimentation and dissection on wartime bodies occurred for a number of reasons. The high number of casualties required a substantial change in the public's attitude toward death. Faced with daily accounts of lost husbands, sons, brothers, and neighbors, northerners responded by imbuing death with a heightened sense of purpose. Over time the public began to see the value in doctors studying their loved ones' remains. Ironically however, medical personnel also came to signify the pain and suffering of individual soldiers due to their proximity with disabled bodies. Surgeons, then, reflected contested meanings as they came to symbolize the ability to both destroy and heal. They felt the scorn of soldiers and their loved ones who were frustrated with atrabilious accounts of the war while also embodying an expansive national, indeed a humanistic, importance. Additionally, the

\footnotetext{
${ }^{58}$ Michael Sappol, A Traffic of Dead Bodies: Anatomy and Embodied Social Identity in Nineteenth-Century America (Princeton: Princeton University Press, 2004), 123-124.
} 
acceptance of death "destabilized ideas about the sanctity of the body," opened the door for medical study, training, and experimentation, on both the dead and wounded. ${ }^{59}$

As soldiers' bodies grew to take on greater meaning in the war, it influenced the structure and personnel of those who worked directly with anatomical specimens. Medical practitioners who joined the war sought to establish their own identities as reputable physicians, courageous healers, and skilled specialists while working within the military medical establishment. The structure developed by the medical department reinforced the importance of professional development based on producing medical knowledge while also saving lives. ${ }^{60}$ The dual attention paid to this prompted doctors and surgeons to abate the prewar competitiveness that fractured the field of medicine during the antebellum period. Though wide spread collaboration did not fully occur until well after the war, antagonisms primarily revolved around the treatment of soldiers or the lack of medical skill, rather than a shortage of patients. Bodies, then, could legitimize the reputable skills of physicians or adversely impact their standing in the medical community.

Treating diseased and wounded soldiers during the war was a unique experience that differed substantially from treating front line soldiers, or even the medical personnel from previous wars. Advances in technological warfare and an increase in the size of armies ensured that the war would be the most destructive in the nation's history. The Mexican American War's bloodiest conflict saw about 3,500 dead and wounded at the Battle of Molino del Rey; by comparison Antietam produced just under 23,000 casualties. Ironically, the very men charged with healing the wounds of soldiers bore responsibility

\footnotetext{
${ }^{59}$ Faust, $173-174$.

${ }^{60}$ Devine, 174.
} 
for their mutilated state. Of all the medical personnel, surgeons were by far the most reviled workers in the Army Medical Department. Typically seen as little more than butchers, they often had a precious few moments to decide whether a battlefield injury required some kind of invasive operation. One visceral image at Gettysburg illustrated the typical carnage of a surgeon's work environment as well as his person. "Near the crude, often makeshift operating table stood the overworked doctor who was splattered with clots of blood and pus and looked more like a butcher than a professional and educated physician. ${ }^{, 61}$ For injured soldiers, a visit to the field hospital surgeon meant the amputation of one's limb, and with it, independence and vitality.

Medical practitioners experienced a constant barrage of slander hurled in their direction. Operating under a litany of suspicion, criticism and frustration, physicians endured blame for the bulk of pain and suffering in the army. The parallel between destroyed bodies and damaged reputations was a poignant one for surgeons in military service, one that could have a lasting effect on his career. While working in Baltimore, Cyrus Bacon was quick to point out the contributions provided by non-medical volunteers, "two gentleman from the Christian Commission come \& put their hands in and help when we need help so much." His opinion, however, changed suddenly when he spoke about his colleagues. After the military victory at Gettysburg, the Medical Corps fought its own war against rampant disease and injury. Short on medical staff, general hospitals all along the east coast struggled to meet the growing needs of the sick and wounded, about 106 surgeons were left to care for over 20,000 sick and wounded. The shortage of medical professionals meant that every available able body was used in

\footnotetext{
${ }^{61}$ Gregory Coco, Strange and Blighted Land: Gettysburg, the Aftermath of a Battle (Gettysburg: Thomas Publications, 1998), 165.
} 
the relief effort, much to the chagrin of some. "[We have] but six surgeons to operate and dress the wounds of men. These gentlemen, one is president of a Pennsylvania College, the other is a college professor. It is the first time I have seen these agents dirty their fingers." ${ }^{62}$ Confederate surgeon Julian John Chisholm wrote "the limbs of soldiers are in as much danger from the ardor of young surgeons as from the missiles of enemies."

Surgeons often faced criticism for their apparent lack of sympathy for the suffering of their patients. Stories spread quickly about their apathy toward the "ghastly sights." "Gaping upon these [amputated limbs], too often the trophies of the amputating bench, I could have no other feeling, than the whole scene was one of cruel butchery."63 Surrounded by such depictions on a near-constant basis took a toll on even the most hardened physician. In response surgeons created an emotional separation between themselves and the wounded. This separation required surgeons to foster an identity of the "self" that allowed them to disassociate from the barrage of heinous images they experienced. Ironically, it was the desire to create a moral and humanistic identity that caused surgeons to shed sympathetic emotions while working on soldiers' bodies. The divorce between surgeon and soldier was a by-product of the professionalizing medical field, which in turn, resulted from the war itself. As Michael Foucault noted, surgeons were "trained (or bullied) into making" self identities by "imbibing doctrines...of self control." ${ }^{\circ 4}$ However, the separation was not entirely coerced, as one historian argued, "the modern self was desired and pursued by people in search of identity and a moral order, created, agitated, and sustained the new professions, institutions, and fields." ${ }^{\circ 5}$

\footnotetext{
${ }^{62}$ Cyrus Bacon, Papers, July 12, 1863.

${ }^{63}$ Coco, 185.

${ }^{64}$ Michel Foucault, The History of Sexuality, Volume I: An Introduction (New York: Vintage, 1990).

${ }^{65}$ Sappol, 211.
} 
Disassociation from the soldier allowed surgeons to focus more intently on the wounds themselves, an effort that helped save the lives of countless men.

As a consequence of fostering their self-identities surgeons opened themselves up to intense criticism. E.N. Harris, a former secretary of the Ladies Aid Society of Philadelphia, commented on the emotionless state of medical workers. After the battle of Fair Oaks she recalled the extensive pain soldiers experienced at the hands of some surgeons. "The leg had been amputated, and pieces of bone extracted from the arm; which had just been probed. The surgeon unheeding the agonized shrieks of the sufferer, whom I found covered with cold dew...upon his brow. ${ }^{, 66}$ Charges of apathy continued to stigmatize physicians throughout the war. This was made all the worse when reports circulated that wounded soldiers were forced to watch surgeons saw off the limbs of their comrades, which only foreshadowed their own circumstances. As Lieutenant Charles Fuller waited for the surgeon's knife he was placed on a table that gave him a full view of amputee patients laid down together, "there, after a few quick passages with scalpel and saw, some rapid winding of bandages, the bloody job was complete." Major Charles Weygnant made note of a similar story during one of his visits to a Gettysburg field hospital. He claimed that one soldier "endured eighteen hours of listening to "the horrid noise made by saws gnawing away at human bones' as he awaited his turn. ${ }^{, 67}$ The situation became so common that Harper's Weekly published artistic renderings of these scenes. ${ }^{68}$

\footnotetext{
${ }^{66}$ E.N. Harris, "Anecdotes of our wounded and dying Soldiers in the Rebellion."

${ }^{67}$ Coco, $181,183$.

${ }^{68}$ Coco, 181, 183. Frank R. Freemon. Gangrene and Glory: Medical Care during the American Civil War (Fairleigh Dickinson University Press, 1998), 47.
} 


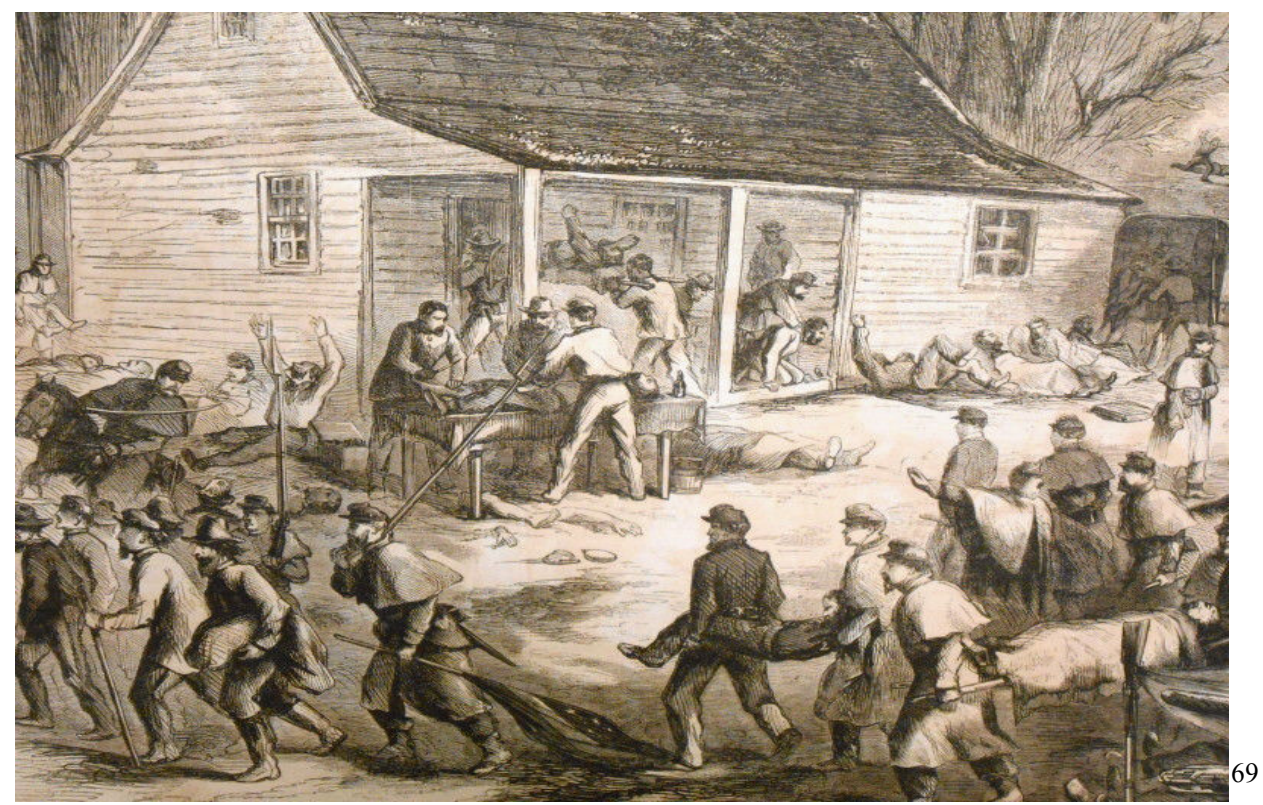

Despite these allegations such attitudes were necessary for the overall success of battlefield operations. Daniel M Holt, a rural doctor from upstate New York experienced his own emotional transition as he learned to quell the horrors of the battlefield in order to better perform his job. In 1861 , he joined the $121^{\text {st }}$ New York Volunteers as an assistant surgeon because he felt could "do [his] duty in the field." Holt entered into a world of military medicine that was drastically different from rural remedies. His regiment saw action in nearly all the major campaigns in the eastern theater of the war. ${ }^{70}$ His own experiences transition from one of shock to that of ambivalence and finally to apathy. Writing to his wife Louisa in September of 1862, Holt noted that he was taken aback by the carnage of war admitting that he "never once expected" to see a rebel "with his brains blown out, arms extended, and eyes protruding from [the] sockets." For days Holt wrestled with the perverse images of war. After just two weeks, however, he

\footnotetext{
${ }^{69}$ Harper's Weekly. December 27, 1862.

${ }^{70}$ James Greiner, A Surgeon's Civil War: The Letters and Diary of Daniel M. Holt, MD (Kent: Kent State Press, 1994), xi.
} 
became fascinating by the various methods of death and injury. Soon he began touring battlefields, and on one occasion he encountered a Confederate "shot through the head with a Minnie ball," noting that the bullet "[took] off almost the entire portion of the skull.” Intrigued by the sight, Holt sought out mementoes of the occasion. He joined his comrades in taking buttons, gold laces, and locks of hair as "relics" to be "appropriated" by the Union men. Holt even took a piece of lace from a coat sleeve and sent it home to his wife. Holt recognized the impact that deformed bodies had on his perception of suffering, "to be transferred from the scenes of quiet where the effects of war [were] not perceptible, to these fields of slaughter and to become participant in the deadly contests is something which never extended into my head." Noting that war itself had a transformative effect; he lamented the loss of his humanitarianism. "Had one told me a year ago that I could look upon such horrors and feel no mental disturbances, I should not have believed them." He continued his unremorseful sentiments, "I pass over the putrifying [sic] bodies of the dead and feel as little unconcerned as if they were two hundred pigs. Their protruding bowels, glassy eyes, open mouths, ejecting blood and gases, affect me not." ${ }^{\text {71 }}$ For Holt, the association with maimed and destroyed bodies sapped his ability to sympathize with the soldiers who suffered most in the war.

Despite the fears of some medical personnel over the loss of their humanity, wounded bodies that survived the war became a living testimony to the overall success of their methods. "Honorable scars" served to illustrate the sacrifice that amputates made to the war effort and helped the wounded reaffirm their masculine identities. Elbert Fuller recognized how his own limbs contributed to the Union victory. "I had the misfortune of receiving a severe wound in the elbow joint which rendered amputation absolutely

${ }^{71}$ Greiner, 20-21. 
necessary in order to save my life...but I have the proud satisfaction of knowing that I have done my country some service."72 These wounds, however, did more than exemplify the valor of disabled soldiers; they proved to be equally beneficial to the men who wielded the knife.

Recognition for one's skill and courage could mean professional acclaim for surgeons who wished to advance their careers after the war. Often times the reputation gained during the war followed surgeons and doctors home. Newspapers often printed daily lists of the dead and wounded when local regiments were involved in battle. Additionally, war journalists printed the names of physicians who distinguished themselves during the conflict. Following the battle of Cross Keys, the Harrisonburg Register noted that federal surgeons working in Confederate hospitals were "unremitting in their attentions to wounded and sick prisoners....all [are] gentlemen of intelligence and skill in their responsible profession, and have done all that could be accomplished to relieve the suffering of others." ${ }^{, 73}$ After the battle of Gettysburg one soldier made note of the surgeons' dedication to injured soldiers. "The wounded laid in soaking rain, and without shelter or bedding or care or food or attention of any kind. How I saw men die, leaning against a trees and lying half-naked on wet ground and helpless with amputations and loss of blood, horrors nameless. The doctors overworked and passing sleepless nights and doing all they could to reach all. The country for miles back of the field was one vast hospital." 74

\footnotetext{
${ }^{72}$ Frances Clarke, ““'Honorable Scars:” Northern Amputees and the Memory of Civil War Injuries,” in Union Soldiers and the Northern Home Front: Wartime Experiences, Postwar Adjustments ed. Paul Cimbala and Randall M. Miller (New York: Fordham University Press, 2002); Brian Craig Miller, Empty Sleeves: Amputation in the Civil War South (Athens: University of Georgia Press, 2015).

${ }^{73}$ Rockingham Register, July 4, 1862. Quoted in Dale MacAllister, Civil War Hospitals in Harrisonburg, Virginia. 2010. p 8.

${ }^{74}$ John W. Ames, Papers, 1861-1863, Letter to his Mother. July 19, 1863.
} 
Despite the vitriol launched their way skilled surgeons could improve their professional status providing they had access to disabled bodies. Wounded bodies were vital for inclusion into elite circles of the medical field. Not only did these men improve their own standing, but their successes improved the overall public opinion of the field. Cyrus Bacon of the 7th Michigan Volunteers commented on his colleague's handiwork stating, "Dr Hewitt operates very prettily." Speaking on a recent leg amputation he said, "it is the best stump that yet has been made. It is very nice."75 Amputations were so common during the war that "a skilled 'operator' with a good scalpel and a sharp medical saw could remove a leg or an arm in as little as half a minute." ${ }^{76}$ However, a reputable surgeon needed to demonstrate capabilities beyond knife. After the battle of Chancellorsville one man commented on his peer, "Dr. Billings is a very fine operator. Still his chief point is his judgment and his power of diagnosis. He forms rapid conclusions of a case and is quite invariably correct." ${ }^{, 77}$

Surgeons who built their reputations enough soon found that soldiers actually requested their services. During his time in a Washington general hospital Thomas Ellis recalled the first time a patient specifically requested his skills for a necessary operation. "Among the wounded which arrived from the field on Wednesday, was a young private of the 1st Long Island regiment, son of Captain Sitwell, of that Corps, who had been shot through the body. This gentleman requested my care for young Sitwell." According to Ellis, his fame continued to grow unexpectedly. He had served on various hospital transport ships and in general hospitals throughout the entirely of the war, during which time he attended to thousands of wounded soldiers. Given the chaos surrounding

\footnotetext{
${ }^{75}$ Cyrus Bacon, October 9, 1862, October 3, 1862.

${ }^{76}$ Coco, 164.

${ }^{77}$ Cyrus Bacon, May 5, 1862.
} 
transport ships and hospitals, he freely admitted that he could not remember the names and faces of all the men he treated. Much to his surprise, however, he quickly became a recognized figure in his own right. During a trip to Philadelphia he recalled, "On my arrival at the U.S. Hospital, I was unexpectedly greeted with a hearty cheer from the poor fellows, as they lay on their comfortable beds many of their faces were quite familiar to me, but the number I had attended during the preceding week was so large that I could not possibly recollect them all. They, however, generally recognized me, and expressed their thanks. ${ }^{, 78}$ Honorable scars, it seemed, played a prominent role in erasing stigma associated with disabled bodies for both soldiers and physicians.

Wounds provided more to medical professionals than just the growth potential of esteemed reputations. Simply working with wounded men tested the strength and resolve of medical experts, especially in the days following a major battle. During the war, over ninety five percent of all operations used some manner of anesthesia, however, in a few cases soldiers actually refused any medicines that dulled the senses. These rare cases tested the resolve of surgeons just as much as their patients. One soldier of the $5^{\text {th }}$ Alabama was so concerned with the loss of his senses that he objected to any form of anesthetic. As the surgeon prepared to amputate his limb the soldier exclaimed, "Cut the leg off Doc, but leave off the chloroform; if you can stand it I can." 79 The challenge issued by the unfortunate patient required the resolve of both the soldier and surgeon to endure the operation. Interestingly, the loss of the leg was secondary to the ability to withstand the pain of the amputation. Whether this anecdote was exaggerated is of little importance. The fact remains that the ability to survive the treatment of painful injuries

\footnotetext{
${ }^{78}$ Thomas Ellis, Leaves from the Diary of an Army Surgeon; or, Incidents of Field, Camp, and Hospital Life (New York: Bradburn, 1863), 72, 82.

${ }^{79} \mathrm{Coco}, 162$.
} 
embodied masculine courage. Further testimony of a surgeon's fortitude came when one soldier noted, "it requires a man of steel nerve and a case hardened heart to be a Army Surgeon." ${ }^{\prime 80}$ General Carl Schurz of the Eleventh Corps witnessed the phlegmatic nature of surgeons in the days following Gettysburg. Transfixed with the scene in front of him, Schurz was determined to absorb the spectacle that surrounded him. Years later he could still vividly recall the events before him.

The Houses, the barns, the sheds, and the open barnyards, were crowded with moaning and wailing human beings, and still an unceasing procession of stretchers and ambulances was coming in. A heavy rain set in during the day - the usual rain after a battle - and large numbers had to remain unprotected in the open, there being no room left under roof. I saw the long rows of men lying under the eaves of the buildings, the water pouring down upon their bodies in streams. Most of the operating tables were places in the open, where light was best, some of them partially protected against the rain by tarpaulins or blankets stretched upon poles. There stood the surgeons, their sleeves rolled up to the elbows, their bare arms as well as their linen aprons smeared with blood... around them pools of blood and amputated arms or legs in heaps, sometimes more than man-high. ${ }^{81}$

As we have seen, medical practitioners were trained to interact with a variety of gruesome injuries with a steel nerve. However, doctors and surgeons who were asked to interact with a soldier's loved ones often faltered. While Emily Souder boarded a train for Gettysburg she struck up conversation with an Ohio surgeon bound for the field hospitals. After a few minutes the surgeon admitted to his inability to engage with the sentimental side of patient care. "[I] can take a man's leg off, in necessary and not mind it; but when a man says 'Can't you write to my wife and tell her how I died and tell her to kiss Mary,' that I cannot do." ${ }^{\prime 2}$ Civil War surgeons were unlike medical personnel during times of peace. They were not prepared, nor equipped, to merge the emotionalism of bedside manners with that of surgical operations. Much like Brinton's aforementioned

\footnotetext{
${ }^{80}$ Coco, 181.

${ }^{81}$ Carl Schurz, "The Battle of Gettysburg," McClure's Magazine, XXIX, (1907), 285.

${ }^{82}$ Emily Souder. Leaves From the Battlefield of Gettysburg: A Series of Letters from a Field Hospital (Philadelphia: Caxton Press, 1864), 13.
} 
anecdote of Lincoln's visit to the hospital, the surgeon's craft necessitated a clear mental delineation between their work on the wounds themselves versus the soldier.

The growth of the medical department had a dramatic impact on the way doctors from various medical backgrounds viewed each other. As the number of bodies increased, so too did the anatomical training and experimentation. Standardization of medical treatments slowly pervaded camps, field hospitals, and general hospitals, and inter rivalry antagonisms decreased over time. Regional biases, however, continued to plague the medical department. Western doctors were viewed as "odd characters" with a persona unto themselves. Eastern doctors, who worked in the finest most well respected medical schools in Philadelphia and Boston, carried an air of superiority that they held over backcountry physicians. While eastern physicians may have held more prestigious positions prior to the war, they were less well regarded on the battlefield. John $\mathrm{H}$. Brinton recalled one instance at the battle of Fort Donelson, where he came across a western surgeon from the $18^{\text {th }}$ Illinois Infantry. Brinton found Henry Winter Davis to be "a most impulsive, efficient, outspoken man," who entered the battlefield with a gun in his hand "firing away with great spirit." Taken aback by the sight of a surgeon fighting on the front line Brinton called out to Davis. "Doctor," Brinton said, "this is hardly the work for you to be doing, you ought to confine yourself to strictly professional work." Davis looked up at Brinton astride his horse and took on a wry expression, "I'm all right, Doctor, I have done all the surgery of this Regiment, and have fired forty-five shots, by G-d.” Ignoring Brinton's insinuations Davis pointed toward the easterner's own position 
on the battle line and stated, "I'm glad you're not a feather-bed doctor," after which Davis continued his "belligerent" pastime..$^{83}$

Despite working behind the front lines medical personnel were often placed in precarious situations. Armies were subject to a constant state of ebbs and flows once a battle began. Field positions could change suddenly and without warning as regiments entered into a series of flanking maneuvers and counter attacks. Responsible for the care of wounded soldiers, however, field hospitals remained in a fixed location. A surgeon's duty demanded that he remain with the injured regardless of how the conflict fared. Physicians routinely found themselves on the wrong end of a retreating army. While able-bodied men could simply walk in the opposite direction of their foe, severely injured soldiers could not be evacuated before an advancing army arrived. It was common for retreating armies to leave wounded soldiers behind with the expectation that enemy combatants would provide and care for them. Surgeons tended to wounded soldiers, refusing to stop even as the enemy walked into their field tents. Early in the war, Union and Confederate officers agreed that medical personnel occupied a privileged position beyond the scope of the conflict. Physicians and nurses were officially considered noncombatants and were entitled to preferential treatment. Philosophically speaking, doctors were antithetical to the basic premises of warfare. It was a soldier's job to kill and a doctor's job to heal. So while an injured soldier could become a prisoner of war, medical personnel stayed among the enemy tending to the wounded on both sides. Medical personnel were then sent back to their regiment once the majority of injured soldiers received treatment.

\footnotetext{
${ }^{83}$ John H. Brinton, 126-127.
} 
Working with disabled bodies offered a level of protection behind enemy lines. One group of rebel surgeons actually drank to the health of Jefferson Davis in a northern saloon full of Union soldiers. Cyrus Bacon took great umbrage at their brash behavior. "They would string us up should we do the like for Lincoln in the South. They were only arrested and ordered at once to leave the states." This openly defiant stance stood in stark contrast to the behavioral expectations of well-bred physicians. "But Surgeons are not prisoners of war. [They] are treated as gentlemen, therefore their offense is greater because as noncombatants they cannot be punished." ${ }^{84}$ After the battle of Chancellorsville, Bacon found the situation reversed when he was left to care for wounded soldiers following the Union retreat. He observed much during his time among the enemy, and commented on the differences between northern and southern transport systems. "The ambulance system of the Confederates is different than ours. An Assistant Surgeon of the army is in charge of the ambulance train instead of a line officer. Their ambulances are a conglomerate mixture. Some are good and likely some of them had been ours, or a sutler's wagon." Bacon's time among the rebel army softened his earlier stance, particularly after he met with a Dr. Holt of the Confederate army. Stubbornly adhering to his reputation as a gentleman surgeon, Bacon routinely argued with lower ranking medical staff. "Early I had some words with one of their surgeons who called me a prisoner, a title which I refuted. They however seized a couple of old instrument cases. The shits." However, Dr. Holt made it known to all his staff that a Union surgeon was to be treated with all the respect and dignity afforded a man of his station. "When we arrived at Dr. Holt's, the doctor was very angry" over the incident with the instrument cases and ordered them returned immediately. "I must say, I think

\footnotetext{
${ }^{84}$ Cyrus Bacon, Letter October 22, 1862.
} 
under all circumstances Dr. Holt is exceedingly gentlemanly \& courteous toward us.” The status and reputation men garnered from working with diseased and wounded men awarded them with unique privileges even when behind enemy lines. ${ }^{85}$

The very nature of a surgeon's profession demanded an invasive approach on the wounds of soldiers. Many physicians who volunteered in the war did so in the hopes of gaining access to anatomical specimens. A lack of strict oversight meant that doctors and surgeons could try new techniques even in the pandemonium of field hospitals. One medical practitioner noted that "as busy as most medical people were, there was often at Gettysburg as elsewhere opportunities for experimentation if a doctor found himself the time. ${ }^{\prime 86}$ As science gained increased acceptance in the field of medicine, physicians sought ways to contribute to the accumulation of professional knowledge. The disabled forms produced by the war offered physicians the opportunity to test new treatments and innovations, thus laying the foundations for significant developments in American medicine. Julian John Chisolm developed a specialized inhaler to control dose of anesthetics on Confederate soldiers. Chisolm was something of a military medical expert by the time South Carolina seceded from the Union. In the 1850s he toured European military hospitals studying various treatment techniques. He brought his experiences back home and immediately sought to improve upon the administration of chloroform. The typical application of anesthetics called for the liquid to be poured over a folded cloth or handkerchief that was placed over the mouth of the patient. This method had the unintended consequence of the anesthesia evaporating "into the air of the room" and influencing "all persons around the patient," including the operator. For a Confederacy

\footnotetext{
${ }^{85}$ Cyrus Bacon, Letter May 7' 1863.

${ }^{86}$ Coco, 166.
} 
short on medical supplies, the inhaler helped limit the potential for waste. Chisolm's device required the patient to inhale a mixture of chloroform mixed with "atmospheric air and required only a $1 / 8^{\text {th }}$ ounce of liquid versus the two ounces required by the handkerchief method. It was also small enough to fit a vest pocket or lancet case with ease. ${ }^{87}$

Over 60,000 amputations took place during the war, the equivalent of approximately three-fourths of all operations. As the war progressed the Union medical department complied enough information to publish detailed accounts of the most successful methods. Training books circulated among military physicians that detailed step-by-step instructions for the removal of a patient's limb. If the injury required amputation at the ankle-joint, for example, surgeons were expected to utilize the Syme's method. "Operation - The foot being placed at a right angle to the leg, a line drawn down from the center of one malleolus to that of the other, directly across the sole of the foot, will show the proper extent of the posterior flap...The anterior incision should join the two points just mentioned at an angle of $45^{\circ}$ to the sole of the foot and along the axis of the leg." These guides even provided specific accounts of how a surgeon should position their hands upon a leg in preparation to amputate. "In dissecting the posterior flap, the operator should place the fingers of his left hand upon the heel, while the thumb rests upon the edge of the integuments, then cut between the nail of the thumb and tuberosity of the os calcis, so as to avoid lacerating the soft parts." The guide went on to detail the recovery period a soldier could anticipate post surgery. It identified one man

\footnotetext{
${ }^{87}$ George Tiemann \& Company, Collection of advertising brochures, National Library of Medicine, Washington.
} 
who had the surgery years prior and who could routinely walk eight miles a day without "fatigue or inconvenience from his mutilated limb."

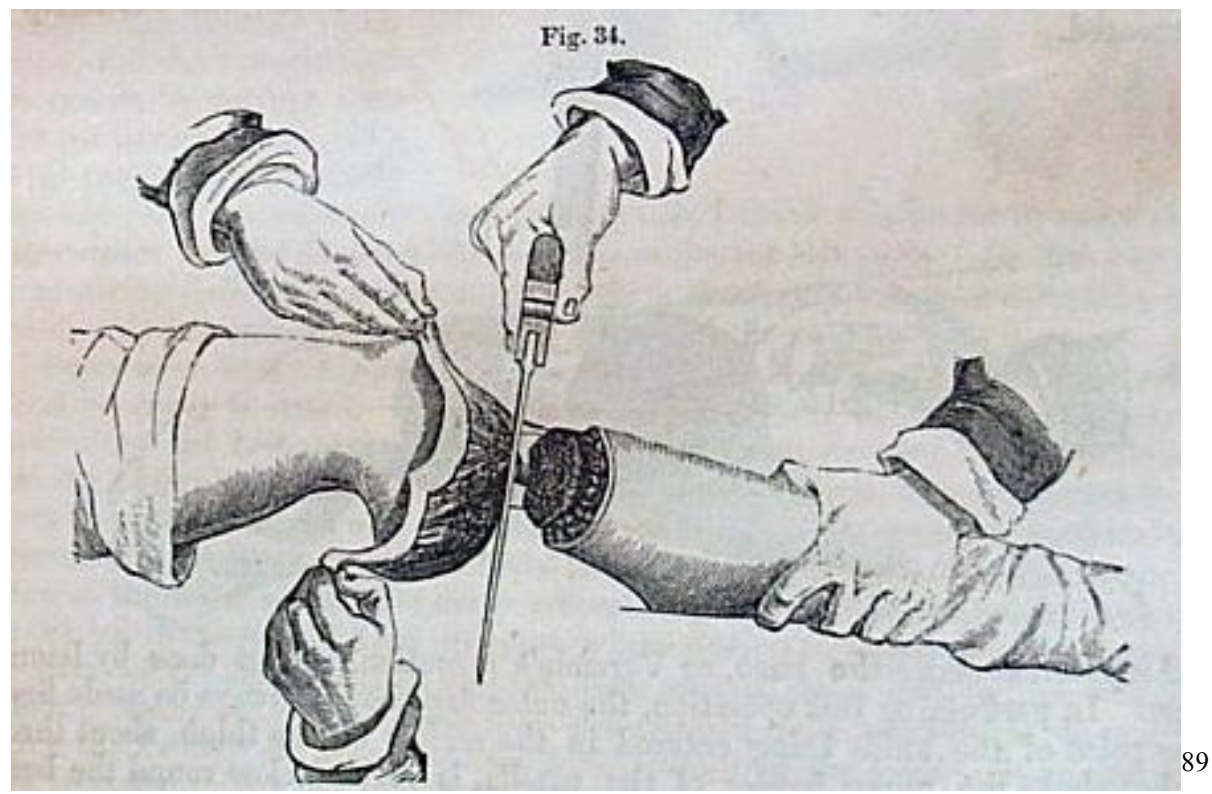

The impact of surgical methods resonated well beyond the treatment of patients. Spectators of these operations stood transfixed by the medical challenges presented by injuries of war. Many who observed operations wrote as if they were witnessing the exhibition of living art. One nurse commented shortly after the Battle of Fredericksburg, "there was an uncanny sort of fascination in watching him [the doctor]. The poor private with both legs off and shot through the lungs, possessed more attractions for him than all the wonders of the world." In the same way that Barnum's city patrons were titillated by the dual sensations of entertainment and horror, so too did witnesses experience pity and

\footnotetext{
${ }^{88}$ William Alexander Hammond, “Amputations," Military Medical and Surgical Essays (Philadelphia: J.B. Lippincott \& Co., 1864), 474, 484.

${ }^{89}$ Step by step illustrations were published in training manuals and distributed among doctors and surgeons in the Union Army.
} 
awe when watching surgeons operate. ${ }^{90}$ The nurse's assessment went on to acknowledge the wonders of the "mysterious...mechanisms" of the body. ${ }^{91}$ The artistry involved in operational procedures fascinated onlookers so much so that Frederick Winsor of the $49^{\text {th }}$ Massachusetts implored citizens to "realize the surgeon's experience." He argued that witnesses must "see with his eyes and hear with his ears," and to "feel with him; for he and his patients are all feeling...they feel the suffering., he feels with the sense of touch, the skilled touch. ${ }^{92}$ The reputation appropriated by this artistic craft spread quickly through the army. Private George A. Allen of the $76^{\text {th }}$ New York Volunteers, wrote to The Antietam Wavelet that "Dr. Vanderkief was the boss in taking off a limb. He could snatch off a leg or arm quicker than you could say 'Jack Robinson,' and it was done right too. No more trouble or second amputation." ${ }^{, 93}$ Increasingly, ravaged bodies provided doctors with opportunities to hone their precision and skill. "The amputations of severely damaged limbs became a common practice as well as necessary, and a skilled 'operator' with a good scalpel and sharp medical saw could remove a leg or an arm in as little as half a minute. ${ }^{.94}$

\section{Concluding Wounds: Medical America}

Wounded bodies were imbued with an overlapping variety of complex, and oft times contested, meanings that did not necessarily extend to the soldiers themselves. The men who interacted with these disabled bodies viewed them within the context of their own

\footnotetext{
${ }^{90}$ Louisa May Alcott, Hospital Sketches (Boston: James Redpath Publishing, 1863), 42-43.

${ }^{91}$ Alcott, 42-43

${ }^{92}$ Earl Hess, Union Soldier in Battle: Enduring the Ordeal of Combat (Lawrence: University of Kansas Press, 1997), 36.

${ }_{93}^{93}$ George A. Allen, The Antietam Waverly, March 29, 1890.

${ }^{94}$ Coco, 164.
} 
needs, experiences, and perceptual tropes. The disparate field of medicine in the antebellum period required a catastrophic event to force medical professionals beyond interpersonal competition and argumentation. The war allowed the government to create an umbrella organization that standardized the documentation and treatment of disease and injury, thus ensuring a higher standard of care across a broad spectrum of physicians. Surgeons, in turn, not only advanced the overall practice of medicine but they also improved the personal, national, and international reputation of the field. In short, the disabled bodies produced by the war put American medicine on the map. In the postwar years American medicine slowly began to edge out European centers in reputation and standing. Nations from all across the globe wrote to the Army Medical Museum requesting copies of the Surgical and Medical History of the War of the Rebellion due to the groundbreaking nature of its categorization, treatment procedures, and printed illustrations. J.J. Woodward, curator of the museum and co-author of the six volume set, received so many requests for the series that he was forced to turn down several inquiries. Apart from the international recognition, individual surgeons went on to have illustrious careers. John H. Brinton went on to serve as chair of surgery at Jefferson Medical College; he later founded the Philadelphia Pathological Society. After his court-marshal, which was later overturned due to falsified evidence, Surgeon General William Alexander Hammond became one of the leading neurologists in the nation and began the American Neurological Association in 1874. He was also one of the first medical practitioners to dedicate his practice solely to the study and treatment of mental disorders. As this chapter attests, while the destructiveness of the war itself cannot be denied, the 
disabled bodies generated by the conflict had a fundamental impact on both the development and the perception of medicine in the United States. 


\section{Chapter 2 - "Our first day's experience, a day of horror and yet a day of blessing": Union Nurses and the War}

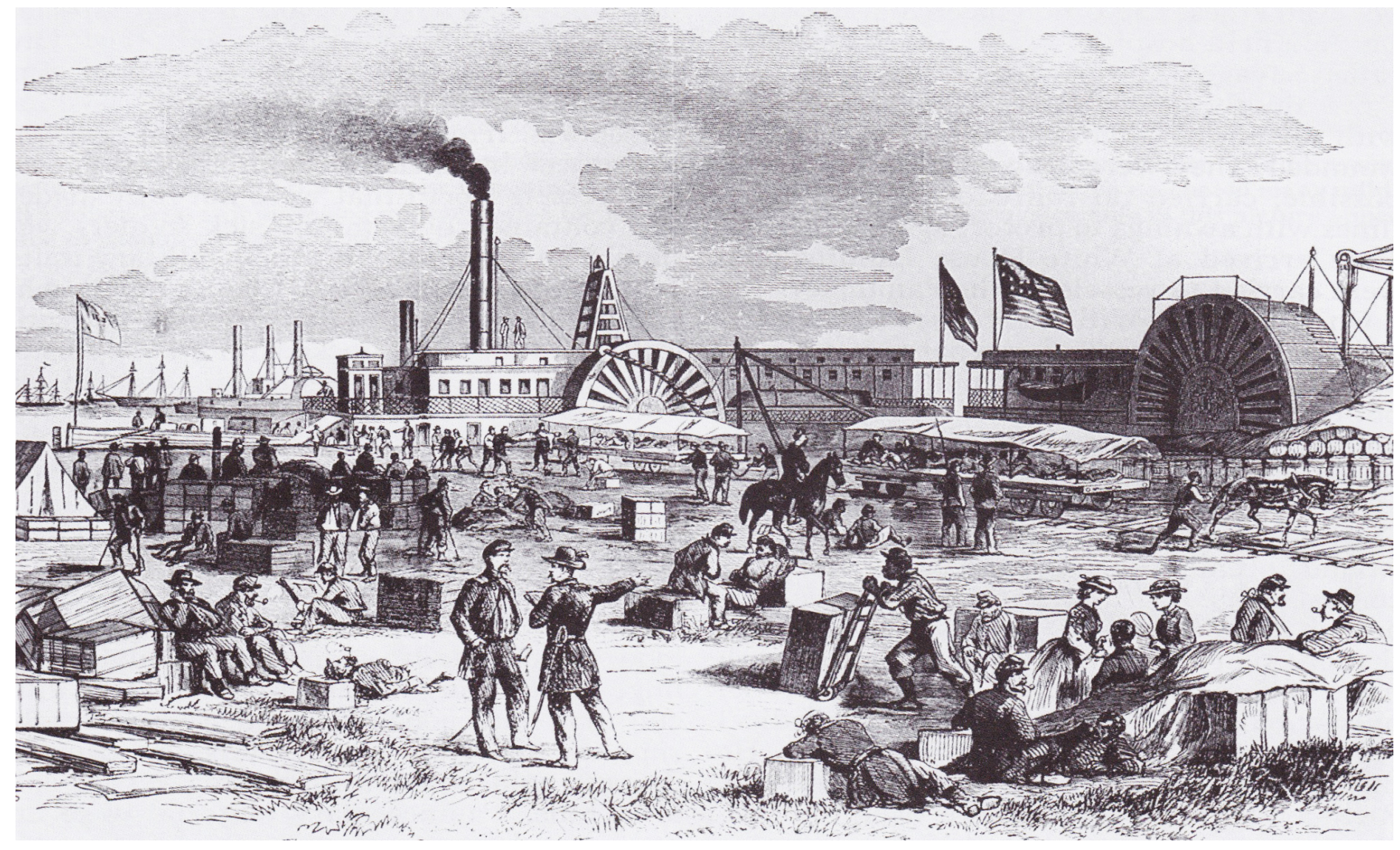

\footnotetext{
${ }^{1}$ Women working with the Sanitary Commission can be seen aiding wounded soldiers in this depiction of the Peninsula Campaign. Nurses are dressed in the usual garb befitting a genteel woman, though evidence suggests that in reality nurses did not don fine dresses with hoops. Railroad flatcars and hospital ships used in the transport of wounded soldiers can be seen in the background.
} 
On the surface, Katharine Prescott Wormeley seemed an unlikely spokes-person to detail the carnage of the Civil War. Born in 1830, to a well-respected military family in England and raised in the fashionable society of Boston and Newport, Rhode Island her family socialized with men like George Templeton Strong and Frederick Law Olmsted. A socialite reared in the affluence of a privileged life, Wormeley embodied all the trappings of a highly cultured young lady. She was active in her community and church, participated in sewing circles, lent her time to charitable organizations, and spent time translating French literary classics into English. ${ }^{2}$ Typically cool-mannered, yet in tune with the suffering of others, Wormeley fit easily into the nineteenth century ideals of refined womanhood. When the war broke out she, along with thousands of other women, tapped into local communities and volunteered their time in the acquisition of supplies for the army.

After "draining her community dry"3 of money and resources, Wormeley began nursing aboard various hospital transport ships along the York River. Most of her time spent on these ships coincided with the 1862 Peninsula Campaign. Like other nurses, Wormeley wrote prodigiously to family and friends, detailing her experiences, thoughts, and philosophies during the war. Wormeley's unvarnished accounts, however, stand out from the letters sent by her peers. Initially timid and unsure of herself, she grew selfassured and authoritative as she continued to work with injured soldiers. During her tenure with the Sanitary Commission she eschewed the growing sense of sentimentalism and romanticism surrounding the conflict, preferring instead to champion the "other side

\footnotetext{
${ }^{2}$ In the postwar period Katharine Wormely received a modicum of fame through her translated literary works of Balzac, the narrative of Marie-Therese, and Alexandre Dumas.

${ }^{3}$ Katharine Wormeley, Other Side of War with the Army of the Potomac: Letters from the Headquarters of the United States Sanitary Commission during the Peninsular Campaign in Virginia in 1862 (Boston:

Ticknor, 1889), 15.
} 
of war." Her letters home did not project a gendered sense of ownership over the "brave boys" of war, nor did they lament the idea of a nameless death. "Our work is not like regular hospital work. It is succoring men just off the battle-field, and making them easy, clean, and comfortable before we turn them over into other hands...when you think that four thousand men have passed through our hands this week, you will understand that we can do little beyond the mere snatching from physical death." ministered to were little more than nameless strangers, a situation to which she was amenable. Wormeley preferred to focus on the interplay between the "sickening atmosphere of wounds," and the ambiguity of Victorian gentility that those wounds provided. Her letters oscillated between a heart-wrenching tragedy and a Shakespearean comedy in a way that allowed her to shed a tear at the destruction around her one minute while finding humor in the wheezing breaths of a seventeen year old boy suffering from a gunshot through his lungs; all while being keenly aware that the "confusion, destruction, and filth about [them] were making a new history."

Wormeley and her contemporaries are a testament to the multifaceted perspective of the human condition. They recognized, and felt intense empathy for, the suffering around them however; they were also cognizant of how wounded bodies provided a means to spurn notions of feminine fragility and subordination. Each interaction with bodies elicited a range of emotions, motivations, and contradictions that existed concomitant with each other. This chapter, then, does not chronicle what these women

\footnotetext{
${ }^{4}$ For more information on sentimentalism and the significance of "nameless" death see Alice Fahs, The Imagined Civil War: Popular Literature of the North \& South, 1861-1865 (Chapel Hill: University of North Carolina Press, 2001); Drew Gilpen Faust, This Republic of Suffering: Death and the American Civil War (New York: Alfred A Knopf Publishing, 2008).

${ }^{5}$ Wormeley, 115.

${ }^{6}$ Wormeley 24.
} 
did during the war, that story has been aptly told by a host of insightful scholars. Rather, it investigates what these experiences meant to middle class women while recognizing, as nurses did, that wounded bodies were the vehicle by which they interpreted their societal importance, especially during the war. It argues that wounded bodies provided the opportunity for genteel women to experiment with perceptual modes like sentimentality, ironic detachment, and the grotesque in order to make claims about gendered capabilities and disabilities.

Any study that investigates how women like Katharine Prescott Wormeley understood and drew meaning from the war, must necessarily discuss how the world, in effect, saw her. It would be an understatement to say that women who wished to experience the war first hand found themselves engaged in an uphill battle. Throughout the nineteenth-century, middle and upper class women fought to reform a series of social cancers plaguing the American public, not the least of which was gender inequality. Their efforts in education, temperance, abolition, the mentally ill, and child welfare all contradicted widely-held social and cultural beliefs about the inferiority of women. Even when men recognized the value of their reform work however, many held to the belief that women were naturally flawed, especially when compared to white men. The long running debate over women's public engagement centered on highlighting these so-called natural physical, intellectual, and psychological flaws. Cynthia Eagle Russet argues that in the nineteenth century "women and savages, together with idiots, criminals, and pathological monstrosities [those with congenital disabilities] were a constant source of anxiety to male intellectuals." ${ }^{, 7}$ So while women embodied the moral guidance necessary

\footnotetext{
${ }^{7}$ Cynthia Eagle Russett, Sexual Science: The Victorian Construction of Womanhood (Cambridge, Massachusetts: Harvard University Press, 1989), 63.
} 
to combat the social afflictions of northern society, their inherently fragile, irrational, and emotionally excessive state made them ill-equipped to handle the pressures of any significant responsibility. Thus, by the outbreak of war nineteenth-century Americans established a belief system that projected a type of socio-cultural disability upon women.

As such, gender historians of the war period have tended to debate whether women in benevolent associations like the Sanitary Commission "masculinized" themselves in order to do their job effectively. This helped to explain the charges of callousness by some of the period. While these studies do much to advance our understanding of the experiences women during the war, they do not recognize the implicit role that wounded soldiers played. Their work exists apart from the suffering of soldiers.

Over the past few decades historians have convincingly linked disability with the feminist movements of the nineteenth and twentieth century. Aileen Kraditor asserts that by 1890 , the youthful voices of the feminist movement infused the ideas of social Darwinism into a right's-based argument for the enfranchisement of Anglo Saxon women. White women, they reasoned, deserved the right to vote in order to offset the growing power of urban immigrants. The new feminist movement tapped into the exclusionary language used to legitimize the federal immigration law of 1882 . Congressional legislation throughout this period identified defective immigrants as unfit for entry into the United States. By 1891, anti-immigration laws allowed examining offers to prevent entry into the United States "any person likely to become a public charge." The "public charge," Douglas C. Baynton notes, intended to encompass 
individuals with disability in general, and was left to the examining officer's discretion. ${ }^{8}$ Such studies, however, tend to pay little attention to the importance of antebellum cultural perceptions of disability, and instead focus primarily on turn-of-the-century politics.

Recently, Civil War scholarship has begun to weave together a number of historical subfields with disability, giving credence to the importance of injured bodies. The soldiers of the Invalid Corps, long considered to be a conglomeration of shirkers, cowards, and the indolent, found redemption in Paul Cimbala's work on the Veteran Reserve Corps. Not only did the chronically diseased and disabled fill crucial roles as guardsmen, hospital stewards, military police and garrisons, but they carried a sense of guilt over their inability to return to the front. The perception of war wounds was a prominent feature of Brian Miller's analysis into the historical memory that surrounded John Bell Hood both during and after the war. Miller views Hood' shifting reputation through the lens of gender studies. Doing so reveals the negotiated power relations between injured men returning home from the war, and the women who took care of them. Megan Kate Nelson's environmental study continues the gendered aspect of disability, highlighting the socio-cultural impact of the visual element of destruction and ruination both on the landscape and bodies. James Marten followed these stigmas into the post war period and their impact on the public debates surrounding federal pensions. ${ }^{9}$

\footnotetext{
${ }^{8}$ United States Statutes at Large, 22 (Washington DC, 1883), 214. Quoted in Douglas C. Baynton, "Defectives in the Land: Disability and American Immigration Policy, 1882-1924 in The Journal of American Ethnic History 24 (Spring 2005), 32.

${ }^{9}$ Brian Miller, John Bell Hood and the Fight for Civil War Memory (Knoxville: University of Tennessee Press, 2010) and "Confederate Amputees and the Women who Loved (or Tried to Love) Them," Weirding the War: Stories from the Civil War's Ragged Edges (Athens: University of Georgia Press, 2011), hereafter cited as Weirding; Megan Kate Nelson, Ruin Nation: Destruction and the American Civil War (Athens: University of Georgia Press, 2012); Paul Cimbala, "Soldering on the Home Front: The Veteran Reserve Corps and the Northern People" in Union Soldiers and the Northern Home Front: Wartime Experiences.
} 
While historians are increasingly apt to include injured soldiers in their argument, they do not portray disability itself as a conceptual framework with which to analyze the nineteenth century. These studies identify the wounded soldier as a primary object placed at the center of the story without analyzing the anterior ideas upon which their object rests. In essence, these studies pick up their story after the injury has already occurred rather than seeing how the concept of disability preceded the event causing the injury. During the nineteenth century men and women increasingly linked differentness with inability. The great triumvirate, race, class, and gender, became a natural identifiers one's capabilities, and was used justify cultural hierarchies. ${ }^{10}$

The concept of disability influenced the meanings women drew from the devastation around them, whether consciously or subconsciously. While studies look at how disability functions historically to justify inequality for disabled people themselves, historians have not investigated how the concept of disability justified the discrimination of antebellum women by projecting it upon them. ${ }^{11}$ Women who tended to freshly maimed victims from the battlefield, implicitly argued that they were not emotionally fragile. When Louisa May Alcott, wrote about the "Spartan firmness" of Nurse Periwinkle in her widely read Hospital Sketches, she was engaging with the public discourse about the delicacy and the irrationality of the female form. For all her "untold agonies" in the midst of diphtheria patients, typhoid patients, and the "dozen dilapidated

\footnotetext{
Postwar Adjustments ed. Paul Cimbala and Randall M. Miller, (New York: Fordham University Press, 2002); James Marten, Sing Not War: The Lives of Union and Confederate Veterans in Gilded Age America (Chapel Hill: The University of North Carolina Press, 2011). For an intriguing analysis of torture and mutilation of bodies, see Barton Myers, "Dissecting the Torture of Mrs. Owens: The Story of a Civil War Atrocity," in Weirding.

${ }^{10}$ Daniel Wickberg, "What Is the History of Sensibilities: On Cultural Histories, Old and New," American Historical Review 112 (June 2007): 661-284.

${ }^{11}$ Douglas C. Baynton, "Disability and the Justification of Inequality in American History." in The New Disability History: American Perspectives ed. Paul K Longmore and Lauri Umansky (New York: New York University Press, 2001), 33.
} 
patriots, hopping....all about," Alcott emphasized Nurse Periwinkle's matronly stoicism. When Katharine Wormeley maintained that one "must put away all feeling...and be a machine," when working with "ghastly objects," she was making a latent argument against the emotional excess of women. Women like Alcott and Wormeley demonstrate not only how much disability figured into the arguments of inequality and gendered stereotypes, but also how women used the disfigured bodies around them to argue against their own sentimental disability. ${ }^{12}$

Just as Joan Scott made an argument for using gender as "a constitutive element of social relationships," disability provides a cultural canvas for understanding how nineteenth century men and women made sense of the world around them. Historians have artfully demonstrated the ubiquity of gender in social thought, but they have been less successful, or perhaps less willing, to imagine how disability is equally a primary component. A cursory look at the 1848 Seneca Falls Women's Rights Convention demonstrates how women viewed disability as central to the legitimacy of the suffragist movement. Delegates of the meeting resolved that the "equality of human rights" necessarily resulted from one's "capability." Utilizing a religious defense, Elizabeth Cady Stanton, Lucretia Mott and others avowed that it was the right and duty of women to participate in political life because their "intellect [was] as capable as a man's ... for if we did not believe it, we would not contend [it]." Even Frederick Douglass proclaimed that "the true basis of rights was the capacity of individuals." 13 As we can see, women were not arguing against inequality for incapable individuals in general. Rather, they argued that a women's natural state, in and of itself, did not constitute a disability. While

\footnotetext{
${ }^{12}$ Louisa May Alcott. Hospital Sketches (Boston: James Redpath Publishers, 1863), 32. Wormeley, 102, 99.

${ }^{13}$ Baynton, 44.
} 
the Seneca Falls Women's Rights Convention stands as an important testament to the dedication and fortitude of the feminist movement, it did little to alter the hearts and minds of many U.S. citizens. Unlike other minority groups, women were not disabled in mind or body and could act rationally and logically, even in times of crisis and hardship. This theme resurfaced in a number of women's rights conventions throughout the 1850s. Throughout these meetings women consistently couched their argument within the "natural-rights" of white women even as they rejected, as one convention attendee argued, the "disabled castes," forced upon them. ${ }^{14}$ Louise Mitchell, secretary of the United Tailoresses Society, urged women to "have more confidence in [their] own abilities," and to reject the notion of "weakness" that men imposed upon them. ${ }^{15}$

Dorthea Dix noted that little had changed for women by 1861 . Serving as Superintendant of Army Nurses Dix complained that women were blocked from demonstrating competence in hospitals, being forced instead to take on tedious tasks. Nurses under her charge were assigned "menial and purely mechanical duties," and were "looked at with a doubtful eye by all but the most enlightened surgeons, and have a very uncertain semi-legal position." Victims of middle-class gentility, these women had "been only too refined for their places." ${ }^{16}$ As Dix and others quickly realized however, the wide scale destruction of soldiers' bodies soon provided the opportunity for women to make an assertive claim about their capabilities. When thousands of women left their homes to work as nurses with the Union Army they were doing far more than bordering the action on the battlefield. Women were using the prevailing notions of disability to

\footnotetext{
14 “Women's Rights Movements," http://www.anb.org/cush rights.html (accessed 8/8/2015).

${ }^{15}$ Lori Ginzberg, Women in Antebellum Reform (Wheeling: Harlan Davidson, Inc., 2000), 94.

16 "The Origin, Organization, and the Working of the Women's Central Association of Relief," Oct. 12, 1861, No. 32, Documents of the United States Sanitary Commission, 2 vols. (New York, 1966), 1: 28-29; italics in text.
} 
demonstrate clear contrasts between the inabilities associated with decimated bodies and their own healthy bodies in the nineteenth century.

Early in the conflict women discovered that their desire to aid the war effort ran counter to popular conventions of the antebellum period. When the conflict began, women were swept up in the same virulent sense of war fever that gripped the minds and imaginations of young men, including Edward Waldo Emerson, the son of famed transcendentalist poet Ralph Waldo Emerson, who upon learning of Lincoln's call for troops, immediately set about raising a local regiment aptly named the Concord Cadets. Fellow Concord resident and author, Louisa May Alcott, commented on the Concord Company in her letters detailing the town's excitement. The town "was in as wild a state of excitement as it is possible for such a dozy old place to be without dying of brain fever. Flags are flapping everywhere, wreaths \& 'Welcome Home' are stuck on every stickable place \& our drum corps, consisting of eight small boys with eight large drums, keep a continual rub-a-dubbing," ${ }^{17}$ Alcott, was not impervious to the enticing fantasies of soldiering. "I like the stir in the air," she wrote, "and long for battle like a warhorse when he smells gunpowder."18 Reeling from the lack of masculine traits that barred her from warfare, Alcott expressed her frustration with her gender arrangements. "I long to be a man, but as I can't fight, I will content myself with working for those who can.” Barred from military action, Alcott, along with thousands of Northern women, attended Lincoln's call in their own way. If Alcott and others could not raise arms against the Confederacy, then they would sew sleeves for

\footnotetext{
${ }^{17}$ Alice Fahs, Introduction to Hospital Sketches by Louisa May Alcott (New York: Bedford St. Martins, 2004), 11.

${ }^{18}$ Louisa May Alcott. Journals of Louisa May Alcott ed. Joel Myerson, Daniel Shealy, and Madeleine B. Stern (Boston: Little, Brown, 1989), 109.
} 
soldiers. Indeed, in 1861, Northern women were "sewing violently on patriotic blue shirts. ${ }^{\prime 19}$

While many women found fulfillment volunteering their time and resources, others felt limited by the narrow avenues of humanitarian aid available to them. Women who sought a more active role in the war soon felt themselves tethered to the Victorian conventions. If Alcott could not just "march off to war" she would look for more inventive ways to get closer to the war front. In 1862, she believed she found a way to leave the confines of Massachusetts by volunteering to teach "contrabands" to read and write in the Union controlled city of Port Royal, South Carolina. Unfortunately, as an unmarried woman she was forbidden to travel alone, as she had "no natural protector" to chaperone her. ${ }^{20}$ Alcott was not the only one to bristle at the Victorian ropes that fastened her to life in Massachusetts. Months of fundraising and relief efforts in her local community of Newport, Rhode Island, Katharine Wormeley led her to conclude that her "work was closing." At the recommendation of Frederick Law Olmsted she offered her services to the Sanitary Commission to work as a nurse aboard transport ships sailing between New York and Virginia. As if sensing the looming controversy, she wrote a letter to her family defending her actions, "I suppose this will rather startle you. But why should it not be done?" The desire to prove their wartime capability was natural to women like Alcott and Wormeley. The chance to offer qualities recognizably useful and direct prompted these women to search for meaningful connections to propel them into the conflict. ${ }^{21}$

\footnotetext{
${ }^{19}$ Fahs, 11.

${ }^{20}$ Fahs, 13 .

${ }^{21}$ Wormeley, 15.
} 
Given the profusion of diseased, injured, and permanently disabled soldiers, the U.S. army quickly recognized the need to devote attention and resources to the hiring of nurses. Private relief organizations like the U.S. Sanitary Commission (U.S.S.C.), along with religious affiliates like the Catholic Sisters of Charity, and the Christian Commission, aided the Army Medical Corp in the transport and care of incapacitated soldiers. The organizational depths of these entities proved invaluable in the requisition of supplies and medical manpower for the Union Army. The notion of female caretakers was not an altogether novel idea; women were long considered the natural caretaker of the home. Women also worked as ward matrons in hospitals associated with almshouses. Despite these avenues of health care, female nurses were not attached to the army at the start of the Civil War. ${ }^{22}$ When administrators realized the war would be a lengthy one, the U.S. Army Medical Department was forced restructure its approach to battlefield medicine. In 1862, Lincoln promoted William Alexander Hammond to Surgeon General of the Army despite Edwin Stanton's objections. Hammond immediately instituted a number of medical reforms including a triage system, the aeration of hospitals, increased record keeping, competency evaluations for doctors and surgeons, the formation of the Army Medical Museum, the ambulance system, and the approval of female nurses. ${ }^{23}$ Despite Hammond's liberal approach to gender arrangements, social standing and respectability continued to play a significant role in dictating appointments women received. While poor women could sew articles of clothing, donate funds, pack

\footnotetext{
${ }^{22}$ Fahs, 15.

${ }^{23}$ William Hammond's poor relationship with Edwin Stanton intensified after he banned the use of mercury as a purgative substance (mercury was a key component in calomel), believing it neither safe nor effective. The resulting controversy, known as the "Calomel Rebellion," put him at odds with many of his colleagues. In 1864, Stanton court-martialed Hammond on charges of "irregularities" in the purchase of medical furniture. The ruling against Hammond was overturned in 1878, when it was discovered that Secretary of War, Edwin Stanton deliberately falsified evidence. Hammond went on to co-found the American Neurological Association and worked tirelessly to reform insane asylums after the war.
} 
provisions, cook meals, or serve as laundresses, they could not take part in nursing wounded soldiers. Attending to wounded soldiers was the province of middle and upperclass ladies. A "lady" embodied the appropriate character and virtue necessary to ease the tender hearts of convalescing men and were to offer moral and religious instruction. Interestingly, even as Alcott reeled at the social conventions that barred her from traveling south to teach African Americans how to read and write, other women regarded these restrictive measures as a means to ensure their gentility. When Wormeley first considered offering her services as a nurse she made sure it would not damage her reputation as a lady. "Mrs. Griffin had gone down with Mr. Olmstead, and by his request. She is a lady, whose presence is guarantee enough that I, or any other women, may go there with propriety. ${ }^{24}$ In her appeals she was careful to include the names Frederick Law Olmstead and Mrs. Ellen Ruggles Strong, wife of George Templeton Strong, who helped found the U.S.S.C.

Wounded men may have provided the means for women to join the war effort but their damaged bodies certainly did not welcome them with open arms. Female nurses faced numerous challenges from both sexes who held tightly to the rigid perceptions of inability. In fact, one of the earliest endeavors to include women in the field of nursing came from Europe, not the United States. Florence Nightingale's documented exploits in the Crimea were quickly taking on a life of their own after her publication of Notes on Hospitals (1859) and Notes on Nursing (1860). The inclusion of women in the United States was not even considered until the Medical Inspector of the British Army, Dr. Muir, suggested that Dorthea Dix employ and organize a contingent of women to aid hospital staffs. Dix, who proved her competency through a history of philanthropic exertions, was

\footnotetext{
${ }^{24}$ Wormeley, 15.
} 
chosen to manage the Army Nursing Corps. Dix was the perfect candidate to supervise the burgeoning nursing department. Prior to the war Dix made a name for herself as a well-respected prison reformer. Dix was strict, impeccably efficient, and dedicated. Aware of the public's scrutiny, Dix was adamant that women maintain a virtuous character while working with the soldiers. She developed strict standards and expectations, much to the displeasure of the women working under her. Under her leadership, only "matronly" women over the age of thirty could serve in the government hospitals, dresses needed to be "brown or black, with no bows, no curls, [or] jewelry." The "prunes-and-prisms," doctrine, as Alcott referred to them, maintained the image of a dutiful and solemn matron figure, thereby easing, though not eliminating, the public and military reticence to the expanded female role. ${ }^{25}$

A virtuous persona was indispensable to women who wished to work with the diseased and wounded. Suspicion of females fell along class lines as critics often pointed toward the unknown backgrounds of the women swelling the nursing ranks. Thomas Ellis, who earned distinction as an army surgeon during the Peninsula Campaign, supported the promotion of Dorthea Dix in general, but questioned the "doubtful age and reputation" of other women. In his diary Ellis portrayed these nurses as little more than con women who took advantage of unsuspecting invalid men for personal gain. $\mathrm{He}$ accused them of embodying the "miserable counterfeit of noble women" in the effort to abuse the "privileges of their ill-assumed position." Under the guise of respectability these women would "plunder the poor wounded soldiers and embezzle the clothing and luxuries generously contributed [....] to the Sanitary Commission." Ellis went on to

\footnotetext{
${ }^{25}$ Fahs, 20.
} 
lambast these "female harpies" who "under the garb of religion and philanthropy, have robbed the dying sufferer of his hard-earned pay, intended for his suffering family."26

Embodying the virtues of gentility, however, did not necessarily protect one from rebuke. John H. Brinton, who gained notoriety as a brigadier surgeon prior to his appointment as curator of the Army Medical Museum, found these Victorian minded women to be such an annoyance that he suggested they felt more entitled to attentions and luxuries than wounded soldiers. In his memoirs he wrote,

Just at this point the craze spread among our good people that the women of this country could make themselves very useful by acting as nurses for the sick and wounded. So out they came,... [and] besieged all officers and persons in high authority. [They] would stalk[ed] into the office of district commanders, and establish themselves solemnly against the walls, entrenched behind their bags and parcels. There they were, and there they would stay, until some accommodation might be found for them. In self-defense the adjunct general would send them to the medical director, and he,... would forward them to the surgeon in charge of the hospitals. To him at last these wretched females would come. "They did not wish much," not they, "simply a room, a bed, a looking glass, someone to get their meals and do little things for them." Can you fancy half a dozen or a dozen old hags, for that is what they were, surrounding a bewildered hospital surgeon, each one clamoring for her little wants? And rooms so scarce and looking glasses so few! And then, when you had done your best, and had often sacrificed the accommodations for the sick to their benefit, how little gratitude did one receive! Usually nothing but complaints, fault-finding as to yourself, and backbiting as to companions of their own sex. In short this female nurse business was a great trial to all the men concerned, and to me at Mound City soon became intolerable. I determined, therefore, to try and get rid of them from the Mound City Hospital. ${ }^{27}$

Brinton was clearly arguing that women were more trouble to the surgeons than they were worth. While Thomas Ellis noted that the addition of women to the medical field, has "hitherto been a source of annoyance to all the surgeons of the army.,"28

\footnotetext{
${ }^{26}$ Thomas Ellis, Leaves from the Diary of an Army Surgeon; or, Incidents of Field, Camp, and Hospital Life (New York: Bradburn, 1863), pp. 302.

${ }^{27}$ John Brinton, Personal Memoirs of John H Brinton: Civil War Surgeon, 1861-1865 (Southern Illinois Press: Carbondale, 1996), 44.

${ }^{28}$ Thomas Ellis, 302.
} 
Men were not the only ones to object to the sudden influx of female nurses, in her memoirs Katharine Wormeley bristled at a letter her colleague received, "MRS.-------'s mother writes dismal letters, which try her very much, --saying for instance, that a lady must put away all delicacy and refinement for this work." In opposition to these sentiments Wormeley argued that working with wounded and disabled men actually heightened the proscribed virtues of middle-class women. In response to the blind criticism of her colleague's relative, Wormeley wrote to her own mother, "Nothing could be more false. It is not too much to say that delicacy and refinement and the fact of being a gentlewoman could never tell more than they do here." Wormeley went on to brag about the support she received from her own family, "I read your letter to Mrs.----- to make her envious. ${ }^{29}$ Even when actively working among the injured some women took exception to the light-hearted nature of their colleagues. Alcott, known for her biased attitude, often wrote disparagingly about the other women who served the military. "I listen to the clack of eight women \& a dozen men; the first silly, stupid or possessed of one idea, the last absorbed [...] in themselves to a degree that is both ludicrous and provoking."30

Objection to women working in hospitals spawned from arguments surrounding the notion of disability. Victorian convention railed at the thought of women cleaning, bandaging, and bathing the naked bodies of strange men, even if they were lame and feverish. Additionally, middle to upper-class women were bred in a society that viewed their innate sense of sentimentalism as an emotional handicap. Women, they argued, were ill equipped to witness the horrific images of warfare. The appearance of mutilated

\footnotetext{
${ }^{29}$ Wormeley, 35.

${ }^{30}$ Louisa May Alcott, The Journals of Louisa May Alcott 114.
} 
bodies, charred corpses, and the "blood and dust" caked on the soldiers' bodies as they lay haphazardly around the battlegrounds fed the pervasive cultural fears about a women's fragility. Religious groups and elite members of the military bureaucracy stood agog at the thought of young women coming into close contact with men whose torn clothes would be an affront to their natural modesty. Coming from battle lines fresh with injury, soldiers were carried into the field hospitals with clothes that were "partly torn from them." The nature of the wounds often dictated the necessity to "strip [soldiers] entirely, so that many of the poor fellows were completely naked." ${ }^{31}$ Rather than allow women to tend to mutilated and half-naked soldiers, Don Buell of the Army of the Ohio Medical Department detailed male nurses strictly for the hospital service. In his estimation, "Lady nurses are not permitted to enter some places owing to concerns about propriety." ${ }^{32}$ Buell's resistance to female nurses was so strong that he instituted a policy where the "sick should care for the sick," rather than employ women. ${ }^{33}$

The notion of capabilities was not simply defined by anatomical characteristics, but rather an amalgamation of gendered stereotypes, age, and physical features. For those who supported the idea of female nurses there existed a direct link between matronly images and their natural aptitude in working with wounded soldiers. Harriet Whitten was one such woman who did not fit the mold. Just twenty years old when she volunteered aboard one of the many hospital transport boats, Whetten was a young and attractive volunteer. Whetten sought to allay the concerns of a relative by minimizing her

\footnotetext{
${ }^{31}$ Gregory Coco, Strange and Blighted Land: Gettysburg, the Aftermath of a Battle (Gettysburg: Thomas Publications, 1998), 171.

32 Ibid.

${ }^{33}$ George Worthington Adams, Doctors in Blue: The Medical History of the Union Army in the Civil War (New York: Henry Schuman, 1952), 62. Buell's wish was not far off the mark. Hospitals often required patients to earn their keep by taking part in cleaning, cooking, guard duties, and the nursing of other patients in an effort to keep costs down. Patients continued to work in hospitals until 1863 when Surgeon General William Hammond made the controversial decision to ban the practice.
} 
role with wounded soldiers. "You must understand that there are men nurses and orderlies detailed so that we volunteer ladies have nothing disagreeable to do. ${ }^{34}$ Walt Whitman himself, who was not opposed female nurses, was adamant that young women did not have the competence to care for diseased and injured men. In his estimation "middle-aged" and "good conditioned elderly women, mothers of children" were best able to care for wounded men. The domestic sphere, he believed, imbued matronly women with a natural "magnetic touch of hands" and instilled "knowledge and privileges, arrived at only through having had children." Consequently, young women could not possess the "practical requirements" necessary to care for wounded men. The natural abilities that came from motherly tenderness acted as the "precious and final qualification" in determining who could work with hospitalized men. Accordingly, intelligence, dedication, and aptitude were secondary. Whitman asserted that one of the finest nurses he ever met was a "red faced, illiterate old Irish woman" who took the "poor, wasted, naked boys so tenderly up in her arms." ${ }^{35}$ Whitman and others constructed a perception of injured men that transformed their fragile bodies into childlike figures that necessitated the care of an experienced matron.

Older matronly nurses also felt uneasy with young women working in hospitals. While volunteering at Georgetown Hospital in Washington D.C., Hannah Roper, a nurse herself, admonished her daughter Alice for considering an appointment for hospital work. "It would not do for you to be here," she wrote "it is no place for young girls. The surgeons are young and look upon nurses as their natural prey." When the implied sexual

\footnotetext{
${ }^{34}$ Harriet Douglas Whetten to Hexie, May 30, 1862 quoted in "A Volunteer Nurse in the Civil War: Letters of Harriet Douglas Whetten," by Paul H. Hass. Wisconsin Magazine of History 48 (1964), 139.

${ }^{35}$ Walt Whitman, Walt Whitman's Civil War ed. Walter Lowenfels (New York: Alfred A. Knopf, 1960), 116.
} 
licentiousness of the doctors failed to take hold, Roper argued for the proper decorum of a young woman. "Wounded men are exposed from head to foot before the nurses." When she failed yet again, Roper turned to the disabled soldiers to make her argument for her. Claiming to speak for the suffering soldiers she wrote, "they object to anybody but an 'old mother."”36

Despite heavy protests, the increasing numbers of diseased and maimed soldiers combined with a severe shortage of medical personnel, forced the Army Medical Bureau and relief organizations to employ female nurses of all ages with increased frequency. By the end of the war nearly three thousand women swelled the nursing ranks in general hospitals, field hospitals, transport services, and a plethora of private institutions. The motivations that propelled these nurses into service varied almost as much as the women themselves. Some found solace in providing care and comfort to convalescing soldiers in general hospitals far from the battle lines, while the horrific displays of suffering in the field hospitals attracted others. "Blood dripping from dangling feet" and the viscous excretions seeping from "amputated arms or legs in heaps," greeted them at the battlefront. ${ }^{37}$ When asked whether she would prefer working in the general hospital in Washington or in the field hospitals near the front Helen Gilson commented, "I prefer my work in the field for there is more suffering. ${ }^{~} 38$ Death, suffering, and wounded men provided a chance for upper and middle-class women to get away from the staid confines of Victorian life. "I never began the year in a stranger place than this," Alcott wrote,

\footnotetext{
${ }^{36}$ Hannah Ropes, Civil War Nurse: The Diary and Letters of Hannah Ropes ed. John Brumgardt (Knoxville: The University of Tennessee Press, 1980), 61.

${ }^{37}$ Ellis, Thomas. 123.; Mary Cadwell Fisher. "A Week on Gettysburg Field," Grand Army Scout and Soldiers Mail, 1883, vol. II. pp. 176.

${ }^{38}$ Helen L. Gilson, Letters, March 24, 1863, Society Miscellaneous Collection, Historical Society of Pennsylvania.
} 
"five hundred miles from home, alone among strangers, doing painful duties all day long, \& leading a life of constant excitement in this greathouse surrounded by 3 or 4 hundred men in all stages of suffering, disease \& death, though often home sick, heart sick \& worn out...I like it." ${ }^{39}$ Though scenes of wounds, disease, and disability that confronted women were graphic, most found them too irresistible to ignore.

As determined as women were to give more of themselves to the war, most found that they did not understand the expectations once they got there. The medical wing of the military was a fast paced and bureaucratically confusing assemblage of surgeons, doctors, supervisors, quartermasters, and chaplains, not to mention the various relief organizations used to mitigate the suffering of soldiers. Administrative buildings and medical care centers were a dizzying array of activity that oftentimes women did not know what to do or to whom they should report. Middle and upper-class women predicated their involvement in relief organizations throughout the antebellum period on efficiency and organization. The chaos surrounding the war was completely foreign to them. While volunteering at the Union Hotel Hospital Georgetown, D.C., Louisa May Alcott wrote distressingly about the persistent bedlam, "for no more perfect pestilencebox than this house I never saw - cold, damp, dirty, full of vile odors from wounds, kitchens, wash rooms, \& stables. No competent head, male or female, to right matters, \& a jumble of good, bad, \& indifferent nurses, surgeons, and attendants to complicate the Chaos still more. ${ }^{40}$ E.N. Harris echoed these sentiments in a letter to the Ladies Aid Society of Philadelphia, "how many thousands have died for want of prompt and efficient

\footnotetext{
${ }^{39}$ Alcott. Journals, 113.

${ }^{40}$ Louisa May Alcott, Journals, 114.
} 
help." ${ }^{41}$ While most women were well versed in the care-taking of relatives in the home, they were at a loss as to how to envision their role in the disarray of military medicine. Some, like Wormeley, simply reverted back toward their domestic roots. "As far as I can judge, our duty is to be very much that of a housekeeper." Wormeley attended the beds, linens, and cooked for patients while maintaining a "general superintendence over the condition of the wards." Three days into her assignment aboard the "Daniel Webster" Wormeley was still unsure about her role among the feverish and wounded soldiers writing, "I have no idea what we are to do, and I ask no questions." however, before women found ways to prove their capabilities despite the cultural debate that surrounded them.

Once they acclimated to their new environment, disease and disability acted as a mechanism for women to re-envision their civic roles. Their letters and diaries demonstrate the shift that occurred as women took on increased accountability and authority in patient care. Wormeley's initial letters demonstrate her comfort as a glorified housekeeper, over time however, she "learned with her eyes" and took on increased responsibility. Within a month of working with wounded soldiers Wormeley took full measure of the value women offered to the war effort. In stark contrast to the diffidence she felt during her first week aboard ship, Wormely chastised an old friend in a letter. "How little you all realize the magnitude of our necessities at your distance from them! Think of a handful of us here to keep order for the wounded of this great army, --I might almost say to keep life in them."43 Defending their capabilities against possible criticism, women noted that their work with wounded soldiers was "very hard and very

\footnotetext{
${ }^{41}$ E.N. Harris. Letters, 1862.

${ }^{42}$ Wormeley, 17, 25.

${ }^{43}$ Wormeley, 114.
} 
real and actual nursing, which includes more than reading, writing, and smoothing pillows." they had the right to work at what suited them, and the right to be strong, rather than dependent and passive." These letters home reflect the ways nurses began to reconsider the subordinate positions they held. As nurses continued to work with maimed bodies they not only asserted their own rights and capabilities but they also questioned longstanding gender distinctions. ${ }^{45}$

The maimed bodies women worked with had an indelible impact on the way they viewed Victorian gender roles. Women were forced to doff the conventional trappings of genteel life for the practical garb of life as a nurse. Her first day onboard the "Daniel Webster" Wormeley delighted in the image of her decidedly plain dress and behavior, "I have done my first work--making the beds. How you would have laughed to see me, without a hoop, mounted on the ledge of a second tier of berths, making the beds on the third tier." ${ }^{46}$ Her sophisticated upbringing did not escape her entirely however, in subsequent letters home Wormeley dipped into her mastery of the French language to note that hoop skirts were "de rigueur" 47 and not befitting hospital service. Though she admitted that she looked "rather medieval" in the more practical work dresses. The attention paid to the practical style of dress remained throughout their time on the hospital transport ship.

\footnotetext{
${ }^{44}$ Whetten to Hexie, June 14, 1862; Hass, 139.

${ }^{45}$ Bennet Smith, "The Women Who Went to War: The Union Army Nurse in the Civil War," Ph.D. diss., Northwestern University 1981), 120. Italics in the original; Kristie Ross, "Arranging a Doll's House:

Refined Women as Union Nurses," in Divided Houses: Gender and the Civil War, ed. Catherine Clinton and Nina Silber. (New York: Oxford University Press, 1992), 105.

${ }^{46}$ Wormeley, 18.

${ }^{47}$ Translation: Required by etiquette or propriety.
} 
"This state of 'things' has reached its climax," Wormeley stated, as she approached her resourceful partner aboard the "Daniel Webster," Georgeanna Woolsey. "Georgy," as she was known, quickly found a solution to their problem. Georgy, who always "suggests the wildest things in the calmest way: Dr. Agnew has some flannel shirts...I shall get him to give me one." Successful in her mission, "Santa Georgy" returned wearing the "graceful costume, and looking especially feminine." Despite Wormeley's sardonic tone, she followed her friend's lead. “ [I] took the hint and have followed suit in a flannel shirt from the hospital supplies; and now, having tasted the sweets of that easy garment, we shall dread civilization if we have to part with what we call our "Agnews." 48 When her time with the wounded soldiers came to an end she lamented her return to the proprieties of upper-class life. Recognizing the symbolism, her final letter stated "The last I saw of Mr. Olmsted he was disappearing down the side of the "Webster" clad in the garb of a fashionable gentleman. I rubbed my eyes, and felt then that it was indeed all over. I myself had risen to the occasion by putting on a blacklace tablespoon [such were bonnets of the period], in which I became at once conventional and duly civilized. ${ }^{49}$

The shedding of genteel behavior proved to be comical to the ladies of the Daniel Webster, but it was a cause for concern among others. One nurse identified as Mrs. Howland, brought her "man-servant" on board with her when she volunteered her efforts to the medical bureau. The man-servant, Maurice, became increasingly distressed over the improprieties of female nurses. Howland, Wormeley, and "Georgie" took great pleasure in the futile efforts to restrain their unfettered behavior. Laughingly, Howland

\footnotetext{
${ }^{48}$ Wormeley, 165.

${ }^{49}$ Wormeley, 206.
} 
wrote, "He [Maurice] is capital, He Struggles to keep us proper in manners and appearance." Recognizing his attempts as a lost cause she continued, "[he] still dreams of les convenances. At dinner-time he rushes through the various ships and wards: 'My ladies, j'ai un petit plat; je ne vous dirai pas ce que c'est. I beg of you to be ponctuelle; I gif you half-hour's notis.' The half hour having expired, he sets out again on a voyage of entreaty and remonstrance. ${ }^{, 50}$ Such behavior would have been socially unacceptable back home however, the graphic nature of the diseased and wounded bodies around them provided a buffer against public scorn.

Working with disabled men allowed nurses to break out of the confined boundaries of their gender, if only for a time. It also gave them the excuse to do it. Behaving un-lady like, whether it be through pilfering, dress, language, or just plain acting silly amidst graphic scenes of mutilation, was acceptable because they were doing it for the "poor soldier." Women like Wormely, Alcott, Woolsey, and others did not just shed their social tethers simply by taking off their hoop skirts. Suffering men provided them with the opportunity to behave in much more drastic ways, all in the name of aiding the soldiers. If working with wounded soldiers showed Wormeley one thing it was that hospital transports were perpetually low on supplies. And being that the demand for supplies was always in abundance it provided Wormeley with the opportunity to take part in some rather unseemly behavior, behavior that would have been down right scandalous in her life prior to 1862. At one point supplies were so low that Wormeley and "Georgy" developed a choreographed scene to garner the needed supplies from various general stores along the York River. One woman, usually Wormeley, distracted the store owner

\footnotetext{
${ }^{50}$ Wormeley, 42. Translation: He still dreams of propriety. At dinner-time he rushes through the various ships and wards: My ladies I have a small dish [meal prepared], I shall not tell you what it is. I beg you to be punctual. I give you a half hour's notice.
} 
on some pretense of wanting to get a closer look at a shelf item, when his back was turned they would "think nothing of watching the propriety of some nicety out of the way, and then pocketing the article." According to letters and diaries, these types of theft occurred frequently. “After the visit, Georgy's unfathomable pocket is a mine of wealth as to nutmeg-graters, corkscrews, forks, and spoons, and such articles. I, being less nimble at pilfering, content myself by carrying off tin pails with an abstracted air." Again, these women used the destruction of the war to justify their theft while reveling in the excitement they felt at shoplifting, "Perhaps our visits do not give the keen satisfaction to others that they do to us. But they are going back to where they can get more; while to us who remain here, such articles are as precious as if they were make of gold." 51

Nurses stripped off their proprieties and conventions, all the while maintaining that they still held them. They took to unusual style of dress, activity and even theft. But wounded men allowed women to do something else; something innocent and innocuous, yet something that belied the reform-minded efficiency of genteel women in the antebellum era. Broken bodies allowed these women to laugh. The maimed figures littering the hospitals, ships, rail lines, and tents forced women to see through the ruination and use humor as coping mechanism to the anguished scenes. Additionally, humor provided nurses with the impetus to step outside their preconceived notions of civility and deride the social conventions placed on them in their communities. Humor acted as a safeguard against the chaos surrounding them, forming what Peter Carmichael

\footnotetext{
${ }^{51}$ Wormeley, 69.
} 
referred to as an "ironic detachment." ${ }^{, 52}$ Ironic detachment could take the form of mockery, as it did when a nurse saw a poet, "with seven holes in him," as "irrepressibly poetic and very comical." The poet, dressed in costume by the nurses, stood on his bed in a "nondescript...poncho, constructed for him by Mrs. Whetten out of an old green table cloth," while he composed a "foolscap" sheet of poetry. The women found the scene "irresistibly" funny. ${ }^{53}$ Even the most painful and pathetic of wounded men drew detached laughter from the nurses. During one of her land excursions, Wormeley and other nurses came across a feverishly injured soldier. Stopping at his Sibley tent, which "often affords us much amusement," the soldier began to rant about how no woman had ever contributed to a war effort as they did during the recent conflict, and no men had ever been better succored. "He looked so funny, declaiming in his hospital rig, that I slipped out of the tent, convulsed with laughter." Others, however, were moved to tears by the pain and suffering they saw, "I felt sorry, and rather, ashamed a moment later, when I saw the tears in the eyes of a gentleman, new to the work, who was with me." She rationalized the scene stating, "we must either laugh or cry; and this work teaches us that we had better laugh, if we mean to be good for anything...I hope I have not seemed heartless in the tone which I have taken; it is that which we all adopt, and, though genuine, it answers a mental prophylactic.".54

Women used humor as a means to justify their work close to injured men. Forgetting the esteem she felt during her fundraising and sewing efforts prior to her work as a nurse, Wormeley became more critical of citizens on the home front. In 1861, she

\footnotetext{
${ }^{52}$ Peter Carmichael, "Soldier Speak," Weirding the War: Stories from the Civil War's Ragged Edge ed. Stephen Berry (Athens: University of Georgia Press, 2011), 274.

${ }^{53}$ Wormeley, 25.

${ }^{54}$ Wormeley, 159.
} 
felt her organizational help with her community was essential to the war effort. She proudly noted that societies sprang into action almost as soon as Lincoln called for the troops, "within a few hours the women of distant towns were at work to supply them. ${ }^{55}$ However, by June 1862, Wormeley considered herself a seasoned veteran of medical disease and suffering. She now mocked those at home for their inability to truly understand the basic necessities a wounded soldier required. In a particularly mocking segment Wormeley wrote, "I am writing on the floor, interrupted constantly to join in a laugh. Georgy is sorting socks and pulling out the funny little balls of yarn and the big darning needles stuck in the toes, while she is making a fringe across my back." She jeered in a letter home, "Do spare us the darning needles! Reflect upon us rushing in haste to the linen-closet and plunging our hands into a bale of stocking!... I solemnly aver that yesterday I found a pair of drawers made for a case of amputation at the thigh. And the slippers! - only fit for pontoon-bridges!” Whereas sewing socks for the soldiers used to represent a dedicated commitment to aiding the war effort, now it was fit for mockery.

Some doctors did not object to female nurses in theory, but rather thought some aspects of medical service more suitable for women. Helen Gilson, an orphan from Boston, proved her value to doctors and surgeons while stationed at various field hospitals. Aside from her formal duties as a nurse, she used her pay to purchase luxury foodstuffs such as custards and eggnog for soldiers who could not chew heavy foods. She also performed funeral services when chaplains were not available. When the Medical Corps attempted to transfer her out of the field hospital and into an urban general hospital she protested, "I would prefer my work in the field for there is more suffering," she wrote. Horace Howard Furness, an associate member of the Sanitary Commission,

\footnotetext{
${ }^{55}$ Wormeley, 15.
} 
defended Gilson's right to work in the field. "As a general rule," he explained, "the battlefield is not the place for women. In the General Hospitals is their sphere of usefulness. But no one who has ever seen Miss Gilson in the Field Hospitals can for a moment doubt but that in her case is the great, almost solitary exception to the rule." Furness went on to quote a wounded soldier after the Battle of Fredericksburg, "If God ever made an angel, she's one." ${ }^{96}$ Apprehension toward women in the hospital services quickly dissipated following the first year of the war. Despite the perceived slight to a lady's dignity, the number of female volunteers continued to flourish, as did their recognized importance. However, when they left their homes to work with diseased and maimed soldiers they were not always prepared for the visual effects of the battlefield.

Though there were few precedents for men and women to witness war prior to 1861, many still expressed shock at what they saw. Many nurses were able to absorb, and later put to words, the mayhem of their first day. When Jane Boswell Moore travelled to the Union Second Corps field hospital, she had difficulty finding adequate ways of describing what she saw "words utterly fall short in describing the appearances of those woods." However, soon Moore was able to decipher the bloody chaos around her. Through focused observation of bodily destruction she was able to differentiate the individual sights and sounds that previously overwhelmed her. Far from evading the gruesome scene, Moore embraced the "shrieks, cries, [and] groans" that resided all around her. Delving into this sensory absorption, she emphasized not only on "those in the tents" but also those laying "on the amputation tables, which were almost always occupied." In her description she notes the heaps of "bleeding limbs" that horrifyingly transfixed her "eye, however cautious." Recognizing her own morbid curiosity, she

${ }^{56}$ Helen L. Gilson, Letters, March 24, 1863 and May 5-10, 1863. 
"could not always avoid" staring at the gruesome display before her. The scene made such an indelible impact on Moore that she believed she would "never will those scenes of suffering pass away; with terrible reality and vividness [I] feel that they must dwell in [my] memory forever." ${ }^{27}$

Even those who were accustomed to the sight of wounded men found that field hospitals challenged their understanding of how destructive war could be. Shortly after the Battle of Gettysburg, Mary Cadwell Fisher, a volunteer nurse from Mower General Hospital in Philadelphia, went to Gettysburg to assist in the aid of injured soldiers. Fisher was no stranger to the gruesome realities of war. As a volunteer nurse in the largest hospital run by the Union army she was acclimated to the sight of gangrene, staph infections, and amputations. As she arrived at an unidentified field hospital however, the scene of wounded soldiers on the battlefield stunned her. "Before this I had learned all the horrors of warfare inside the walls of our crowded [general] hospitals and from the continually passing trains of wounded .... [B]ut here a new revelation of the brutality of war was presented to my eyes." ${ }^{258}$ The orderly row of beds with fresh linens, cleanly bandaged wounds, and the frequent rounds of the hospital staff had been replaced by five hundred men grouped beneath various trees, removed beyond the fighting limits. No beds or cots were provided instead they were lying on the ground "some of them quite literally half buried in mud." Two days after the battle commenced "there was still no shelter for these men." ${ }^{" 59}$

Despite earlier attempts to break out of conservative gender norms, women like Fisher fell back upon familiar Victorian modes when faced with battlefield scenes.

\footnotetext{
${ }^{57}$ Jane Boswell Moore, The U.S.C.C. Maryland Report, 1863, 104-107.

${ }^{58}$ Mary C. Fisher, "A Week on Gettysburg Field," 12, 2-6.

${ }^{59}$ Fisher, 2-6.
} 
Interaction with wounded bodies allowed nurses to oscillate between perceptual modes, as Fisher did when she recovered from her initial shock. Once acclimated, though not necessarily desensitized, Fisher relied upon a preconceived understanding of domestic and sentimental ideals of femininity to shape the care she provided for the men. These ideals instructed women how to care for the decrepit forms before them. They employed a long-entrenched and familiar language in their letters that utilized elements of sympathy, imagined empathy, and protection. However, they understood this language within the context of the horrid, macabre, and bloody. Fisher looked upon the hundreds of wounded soldiers subjected to the mercy of the elements and used this image to make asserted claims about her own importance to the soldiers. Her writing explores her own value by describing the display of human suffering. These men, "wounded, chilled, starving, and racked with pain" Fisher wrote, "oh how they welcomed us." Her account illuminates an image of mutilated soldiers who suddenly cease in their agonies in order to welcome the benevolent Fisher and her colleagues. Her benevolence was also revealed when she looked at men exposed to the hot July sun. The "lucky" soldiers, notes Fisher sarcastically, were packed into huge Pennsylvanian barns. This "charnel house of death" was so full that one could "not step between men" lying there, so much so that even "the stables and lofts" were overcrowded. ${ }^{60}$ Within this ghastly array of human misery Fisher was the angelic nurse who could offer a beacon of light. The "poor wretches had both legs and his right arm torn off by shell" but when the beaming Fisher appeared, "the horribly mutilated faces looked up to us" with hope. The men's "imploring eyes" at the sight of her bringing food and aid" brought out her motherly qualities, which became quite useful because "many had to be fed like infants." Exalting in her feminine

\footnotetext{
${ }^{60}$ Fisher, 2-6.
} 
influence, "I saw tears of gratitude run down the cheeks of men who would have died in the ranks without flinching as they received the food we so gladly gave." ${ }^{91}$ Fisher sentimentalized the manly qualities of the injured soldier while being careful not to step on his courage and willingness to fight. Yet even within this praise, Fisher highlighted her own usefulness and willingness to serve while surrounded by suffering. By allying herself with the soldier, in feeding him like an infant she acknowledged that the dismembered soldiers around her represented her own connection with the war. ${ }^{62}$

Orphaned appendages could symbolize both the physiological and mental difficulties nurses experienced while caring for convalescing soldiers. Curious musings often crept into the minds of nurses like Fisher, as it did when she philosophized over human appendages haphazardly strewn next to an amputation table, "a ghastly pile of several limbs, just as they had been taken from the mangled bodies." She drew herself closer to the bloody, disassociated limbs and lamented, "there was a pathetic horror around those nameless hands and feet, none knowing or caring to whom they once belonged." For Fisher, these decrepit extremities were indicative of apathetic attitudes conditioned by war. Yet, for all the lamentations her curiosity continued to root her next to the pile of limbs. "It was so dreadful, so revolting, that my feet seemed paralyzed and I stood rooted to the spot with horrible fascination." ${ }^{93}$ Fisher's observations indicate more than a macabre fascination with the amputated extremities however. Instead, the disabled bodies provided the foundation for her to prove the steadfast nature of nurses to the reading public.

\footnotetext{
${ }^{61}$ Ibid.

${ }^{62}$ Fahs, 93-119.

${ }^{63}$ Fisher, 2-6.
} 
Nurses who worked in field hospitals often invoked some of the most repugnant descriptions of the wounds they witnessed. What is striking about their language is their determination in playing upon the senses to describe the wounds they saw. Female authors demanded that readers imagine scenes as they transcribed their experiences onto paper. Writing shortly after the Battle of Gettysburg, one nurse described her most repulsive moment working in the hospital. While changing the bandages of Lieutenant Charles Fuller, who had his arm and leg amputated, she noticed "scores of maggots squirming around in the dead flesh of his wounds." The nurse related that the insects were "producing an activity greater than I had ever observed." Days later "the sound of maggots...like hogs chewing on a corn cob" still haunted the woman. Each time she envisioned the sights and sounds of Lieutenant Fuller's wounds she felt "goose pimples go up [her] back in a lively manner." Despite the abhorrent sight and sound of the maggots she used the incident to imagine herself as the wounded patient, "I apprehended that these animals might penetrate my body and I would become a mass of wrigglers." ${ }^{94}$ For this particular nurse, the image took on a figurative life of its own.

In 1862, E. N. Harris, secretary of the Ladies Aid Society of Philadelphia left her home at 1106 Pine Street to volunteer at the hospitals because she saw "how many thousands died for want of prompt and efficient help." From May 31 to June 5, 1862, Harris was aboard the transport ship Louisiana just after the Battle of Seven Pines in Virginia. The ship served as a hospital for the worst injured among the soldiers. After one day of working with these men she was taken aback at the horrors she saw "The whole day had been spent in operating," she explained "In one pile near me lay more than twenty arms, hands, feet and legs! Many will die - all had under gone mutilation in some

\footnotetext{
${ }^{64}$ Coco, 182.
} 
important member!" Harris highlighted the condition of the men who "had not had their wounds cleaned since the battle" and whose wounds were "alive with maggots, and disgusting and sickening to themselves." Like Fisher, Harris used an appeal to the senses to convey the ghastliness of the scene to those reading her letters. "When I left the boat at night I was obliged to wash all my skirts as they actually smelt offensively from being drabbed in the mingled blood of Federal and Confederate soldiers." Throughout the night, she reported, "I was obliged to kneel in it." To make her point even stronger to her audience Harris finishes the letter with the exclamation "Oh my friend this is war! War in all its fearful horrors!" In her letter, Harris obscures the soldier in the background of the tale. Her own senses - seeing amputated limbs, hearing maggots, smelling offensive odors - receives the most attention. Divorcing the humanistic element from the appendages places Harris at the center of the horrifying chaos, which in turn allows the audience of her text to admire her fortitude as she performed her duties. ${ }^{65}$

Harris' prose merged flowery language with repulsive depictions of suffering. She put painstaking effort into creating a flowing writing style that weaved the ephemeral with the grotesque, all the while touching upon familiar themes of love, pity, compassion, revulsion, and mutilation. At times her text highlights the transformation of soldiers into objects of exhibition who substantiate Harris' own personal strength and resolve. In one of her letters, entitled "Anecdotes of our Wounded and dying Soldiers in the Rebellion," she discussed a leg amputation in depth. The attending physician "unheeding of the agonized shrieks of the sufferer" probed and extracted various bits of bone from the shattered limb prior to cutting it through with the knife. Harris contrasted the callous nature of the physician with her own soothing words, using whispers to calm the soldier's

${ }^{65}$ E. N. Harris, Letters, "Fair Oaks Battlefield." 
shrieks as she recited biblical passages, "covered with cold dew and entering the dark valley, whose mists were already fast settling upon his brow." The delirious soldier responded, "Come unto me all ye that are weary and heavy-laden and I will give you rest." Whereas the soldiers" "agonized shrieks" dominated the early portion of the letter, Harris' ability to sedated the disabled man, soon became the focus of the writing. ${ }^{66}$

The transformation of injured soldiers from proud masculine men into disembodied pitiable beings provided a means for female nurses to articulate the atrocities of warfare first hand. Unlike the volunteers working with benevolent associations back home, many nurses found it difficult to draw jingoistic meaning from the sight of wounded men. Though women have engaged in patriotic rhetoric during the act of nursing, the image of mutilated forms rarely elicited such a response. Immediately after one particular battle, Harris walked to the field to administer aid to wounded men prior to the arrival of the Ambulance Corps. As she walked around the battlefield she was struck by the frozen appearance of the dead; caught performing their last mortal acts.

\begin{abstract}
Their positions were sorrowful, some with ramrod in hand, just about to load - others, guns in hand taking aim and others had just discharged the murderous loads! Some were eating! One poor fellow held a potato to his mouth, while a plate with more on lay near. Another clutched a piece of tobacco. Some held their canteens to their lips. Two were singularly poised up on a fence, having been shot in the very act of cro_ing [illeg.]. All denoting fancied security. No doubt many a wife, mother, or sister gazed with pride on these manly forms in their bright new uniforms - now alas!
\end{abstract}

Within this statuesque display of death and injury Harris juxtaposed these forms with what they once were, espousing their heroics and then lamenting their tragic downfall. "How changed! Begrimed with powder and dust, heads and bodies bloated and blackened, the worms already crawling on them, officers and privates alike lying in heaps

\footnotetext{
${ }^{66}$ E. N. Harris, Letters, “Anecdotes of our wounded and dying Soldiers in the Rebellion.”
} 
and piles. ${ }^{967}$ Harris was not alone in her concern for the transformative effects of mangled bodies. Soldiers themselves worried about the ways they would be perceived by loved ones at home. "Again we strove to prepare great noble looking officers that they must lose life or limb! One poor Captain from Massachusetts implored [the] delay [of amputation] 'Oh my poor wife! It will kill her to see me so cruelly mutilated." ${ }^{\prime 68}$

While general hospitals tended to be more phlegmatic when compared to the utter chaos of the field hospital, the scenes were no less graphic. Nurses who worked in urban hospitals provided aid and bandaging, assisted in amputations, cleaned wounds, and cared for the diseased in much the same fashion as those in field hospitals. However, in general hospitals, where convalescence took place over a long-period of time, nurses typically exhibited motherly characteristics while creating sentimentalized versions of injured soldiers. As women worked closely with diseased and wounded soldiers for weeks and sometimes months at a time, it was common to form strong bonds with their patients.

Even famed author and Civil War nurse Louisa May Alcott could not help but to imagine and highlight her own sufferings while working at Union General Hospital in Georgetown. In her widely popular book, Hospital Sketches, she frequently used the maimed subjects around her as representative displays. Unlike Katherine Wormeley who wrote at length about her aversion to romanticized war, Alcott tended to sentimentalize wounded soldiers lying in hospitals. The process of sentimentalizing wounded men acted as an antiseptic to the disfigured bodies of hospitalized soldiers. In effect, it sanitized grievous wounds through perception and imagination. In her observations, Alcott imagined sentimental features of wounded men to "claim possession of the soldier

\footnotetext{
${ }^{67}$ E. N. Harris Letters, Untitled Letters.

${ }^{68}$ E. N. Harris, Letters, "Dudley Farms, June $19^{\text {th }}$ ",
} 
through special knowledge of his real nature and needs. ${ }^{969}$ In this way, Alcott and others, claimed ownership over soldiers' wounds and thereby controlled the way these wounds were displayed to the general public.

Aside from her reimagining of wounded soldiers, Alcott's work also provided insight into how she imagined her own connection with the war. Her reimagining was especially apparent in the third chapter of Hospital Sketches where she described the experiences and emotions of her first few days working at the hospital. After quickly acclimating to sudden finality of death she began to focus on the long-term consequences of disease and injury surrounding her. The difference was profound for Alcott who believed that nobility could follow a fallen soldier on the battlefield, but for the permanently disabled the future was much more ominous and burdensome. It is here, within this perception of permanent, non-lethal, injuries that Alcott began to shift the representative display of suffering onto herself, by imagining another's pain to be her own. "Sitting in a very hard chair, with pneumonia on one side, diphtheria on the other, five typhoids on the opposite, and a dozen dilapidated patriots hopping, lying, and lounging about. All staring at the 'nuss' suffering untold agonies." Alcott is surrounded by diseased and maimed bodies, yet believes she is the one who suffers. Indeed she even begins this excerpt by complaining about the "very hard chair" she is forced to sit on. Her suffering is highlighted by the fact that the hospitalized soldiers stare at her, the "nuss." Surprisingly, despite the variety of diseases and "dilapidated patriots hopping" about she envisioned herself as the one on display; the one who was stared at with recrimination. By consciously imagining herself as the object of display, she integrates herself within the visceral and visual realities of a country at war. Her words ask readers

\footnotetext{
${ }^{69}$ Fahs, 112.
} 
to imagine Alcott as the central figure in the room, the one that carries the weight of her patients' suffering. ${ }^{70}$

At the same time, imagining herself as the bearer of suffering allowed Alcott, like other female nurses during the war, to reflect upon her personal achievements in spite of these tribulations. Her anguish was pointedly concealed "under as matronly an aspect as a spinster could assume." She proudly proclaimed to have "blundered through [her] labors with a Spartan firmness." Here we see Alcott placing her imagined sufferings within an understood language of Victorian womanhood. Despite her condition and her blunders she was able to persevere through strength and resolve. Furthermore, from Alcott's point of view hospitalized soldiers were unable to recognize the self-inflicted pains she put herself through in order to work with disabled men. "I hoped they appreciated, but I'm afraid they didn't.."'11 In Alcott's depiction a desired role reversal of objectification is sought. Instead of wounded soldiers serving as an exhibition piece for the able-bodied nurse, Alcott places herself at the center of the scene. Her desire is to be observed by the maimed men so that they may recognize the sufferings she willingly endures on their behalf.

Alcott illustrated visceral scenes of torment as a lens through which her readers could comprehend the personal strength and "Spartan resolve" common among Victorian women. Her text highlighted the "legless, armless, or desperately wounded" soldiers returning from the Fredericksburg battlefield. Furthermore, her writing demonstrated a woman's ability to compartmentalize the chaotic and graphic scene, thus arguing against the notion of emotional excess. "I was there to work, not to wonder or weep." Her

\footnotetext{
${ }^{70}$ Louisa May Alcott. Hospital Sketches (Boston: James Redpath Publishers, 1863), 32.

${ }^{71}$ Alcott, 32 .
} 
resolve was illustrated later when she was able to cork "up my feelings and return to the path of duty," resuming her responsibilities to the wounded soldiers. Here again we see Alcott thinking about her own sufferings as she is forced to detach herself from the humanistic aspect of emotion and perform her duty with stoic tenacity. As a caretaker Alcott and other female nurses employed a language that allowed them to make assertive claims about their own strength of character.

Alcott's Hospital Sketches offered more than a simple assertion of her own strength and determination, however. Imbued within her text is a statement of her cultural power. She had the ability to praise or denounce the personal qualities of wounded soldiers. Alcott discussed the lingering death of John, an ideal soldier whom she thought epitomized the ideals of nineteenth-century American manhood by combining both feminine and masculine traits. "A "A most attractive face he had," she wrote, "framed in brown hair and beard, comely featured and full of vigor," with a mouth "grave and firm, with plenty of will and courage in its lines," and a smile "as sweet as any woman's." ${ }^{\prime 3}$ Despite John's grievous wounds he projected a "commanding stature; and uttered no complaint" 74 and possessed a "broad chest and muscular limbs." describing his character she noted, "Anything more natural and frank I never saw, and found this brave John as bashful as brave, yet full of excellencies and fine aspirations, which, having no power to express themselves in words, seemed to have bloomed into his character and made him what he was."

\footnotetext{
${ }^{72}$ Fahs, 112.

${ }^{73}$ Alcott, 49.

${ }^{74}$ Alcott, 50.

${ }^{75}$ Alcott, 61.

${ }^{76}$ Alcott, 59.
} 
Alcott also imagined a more feminized aspect of John's character, one that needed the "gentler tendance [sic] of a woman's hands." As John suffered quietly in his hospital bed, asking for no special attention or assistance, Alcott imagined him not as a heroic and daring solider, as she did previously, but as a boy: "My fear vanished, my heart opened wide and took him in," and she gathered "the bent head in [her] arms, as freely as if he had been a little child." Although John was older than the average soldier (almost thirty), and the "manliest man" among the patients, Alcott stressed his boyish qualities. Hospital Sketches illustrated how Alcott used John's debilitating wounds to imagine his "powerless, enfeebled, boyish qualities," in turn, allowing her to project a matronly role. ${ }^{77}$ Her imaginative projection of these soldiers was not lost on her readers. As the Surgeon General at the Union Hospital wrote to her, "These papers have revealed to me much that is elevated, and pure, and refined in the soldiers' character, which I never before suspected. It is humiliating to me to think that I have been so long among them with such mental or moral obtuseness that I never discovered it for myself." ${ }^{, 78}$

Just as Alcott had the power to ennoble a disabled soldier like John to her reading audience, she also commanded the ability to bastardize others by using wounds as a central character flaw. As John slowly died, quietly and solemnly in his bed, Alcott worked through her lamentations by lambasting other wounded men. "Such an end seemed very hard, when half a dozen worn out, worthless bodies round him, were gathering up the remnants of wasted lives, to linger on for years perhaps, burdens to others, daily reproaches to themselves." ${ }^{79}$ Whereas the wounds that John suffered allowed Alcott to see the "real dignity of the Virginia" blacksmith the some other

\footnotetext{
${ }^{77}$ Alcott, 52; Fahs, 112-113; American Publishers' Circular and Literary Gazette September 1, 1863, 346.

${ }^{78}$ Fahs, 114 .

${ }^{79}$ Alcott, 56.
} 
wounded men in the hospital were burdens to her. While John's body represented the ideal "earnest, brave, and faithful" Union soldier, the worn out bodies of other soldiers represented Alcott's sacrifice and suffering. ${ }^{80}$

It is important to note here that the imaginative and representative aspect of Alcott's views were not malicious attempts to subvert or diminish the very real pain and suffering of those under her care. Her work at these hospitals consistently illustrated her authentic concern for wounded men. However, when confronted with these visual aberrations she sought to make sense of these bodily abnormalities by contextualizing them within familiar forms. Through her focus on these grotesque bodies she could feel a range of emotions, including pity, sympathy, and compassion while simultaneously feeling revulsion, horror, and anger. Civil War nurses used these bodies as a way to reimagine their own role in the public sphere.

The visual impact of wounded soldiers allowed nurses to simultaneously step outside themselves and think about the pain and suffering of others, while also serving as a testament to the importance of their participation in the national struggle. Concerning one amputation a nurse confidently wrote, "as soon as a limb was amputated I would take it to the window and drop it outside into the pit. The arms, legs, feet and hands that were dropped into that hole would amount to several hundred pounds. On one occasion I had to fish out a hand for its former owner, as he insisted that it was all cramped up and hurt him." What stands out here is neither the macabre depiction of a pit filled with amputated limbs, nor the image of rummaging her bare hands through the viscous fluids covering the orphaned appendages, but the fact that, given the circumstances, she has the matronly resolve to help the distressed and injured soldier. In taking care of these soldiers

${ }^{80}$ Ibid. 
nurses oftentimes turned genuine sympathy into genuine empathy. In their care taking they employed a language that connected with ideals of womanhood that simultaneously allowed them to make assertive claims about their own strength of character. ${ }^{81}$

Katharine Wormeley, Louisa May Alcott, Georgeanna “Georgy” Woolsey, E.N. Harris, and Mary Cadwell Fisher were just a few of the three thousand women who served as volunteer nurses in the North during the war. Seeking direct involvement in the national struggle rather than the traditional supporting roles they played domestically, female nurses sought to experience firsthand the constants of war. Through their endeavors, they witnessed amputated limbs, mutilated bodies, the horrific effects of disease, and death while providing invaluable aid to sick and wounded soldiers and medical authorities. The activities and influences of female nurses constitute one of the rare aspects of Civil War history that has not been extensively recorded. Most of the secondary sources that exist focus solely on the contribution of female nurses to the wartime medical service. Their activities often had important ramifications in both an immediate and broader social sense for individual soldiers and the nation as a whole. In the telling of their stories they engaged with a host of perceptual modes that allowed them to reject traditional gender norms even as they sentimentalized the suffering of soldiers, to detach themselves emotionally from their work while embracing laughter and dark amusements. As a group, they deserve attention as full participants in the conflict rather than as mere assistants of the main actors. ${ }^{82}$ Tending to wounded soldiers had a significant impact on the way nurses perceived their own capabilities while also representing a means to argue against their own inferior social status. Nurses saw

\footnotetext{
${ }^{81}$ John Schildt, Antietam Hospitals (Antietam: Antietam Publications, 1996), 27.

${ }^{82}$ Ann Douglas Wood, "The War Within a War: Women Nurses in the Union Army," Civil War History 18, (Sept. 1972): 197-212.
} 
themselves by looking into the faces of those suffering around them. They saw connections between the tribulations in escaping domestic confinement and the struggles recently maimed soldier encountered when adapting to the adversities of disability. ${ }^{83}$

\footnotetext{
${ }^{83}$ Hannah Ropes, Civil War Nurse: The Diary and Letters of Hannah Ropes ed. John R. Brumgardt. (Knoxville: University of Tennessee Press, 1980), 3-6.
} 


\section{Chapter 3 - "Gratifying Morbid Curiosity": Gawking at Wounded Soldiers}

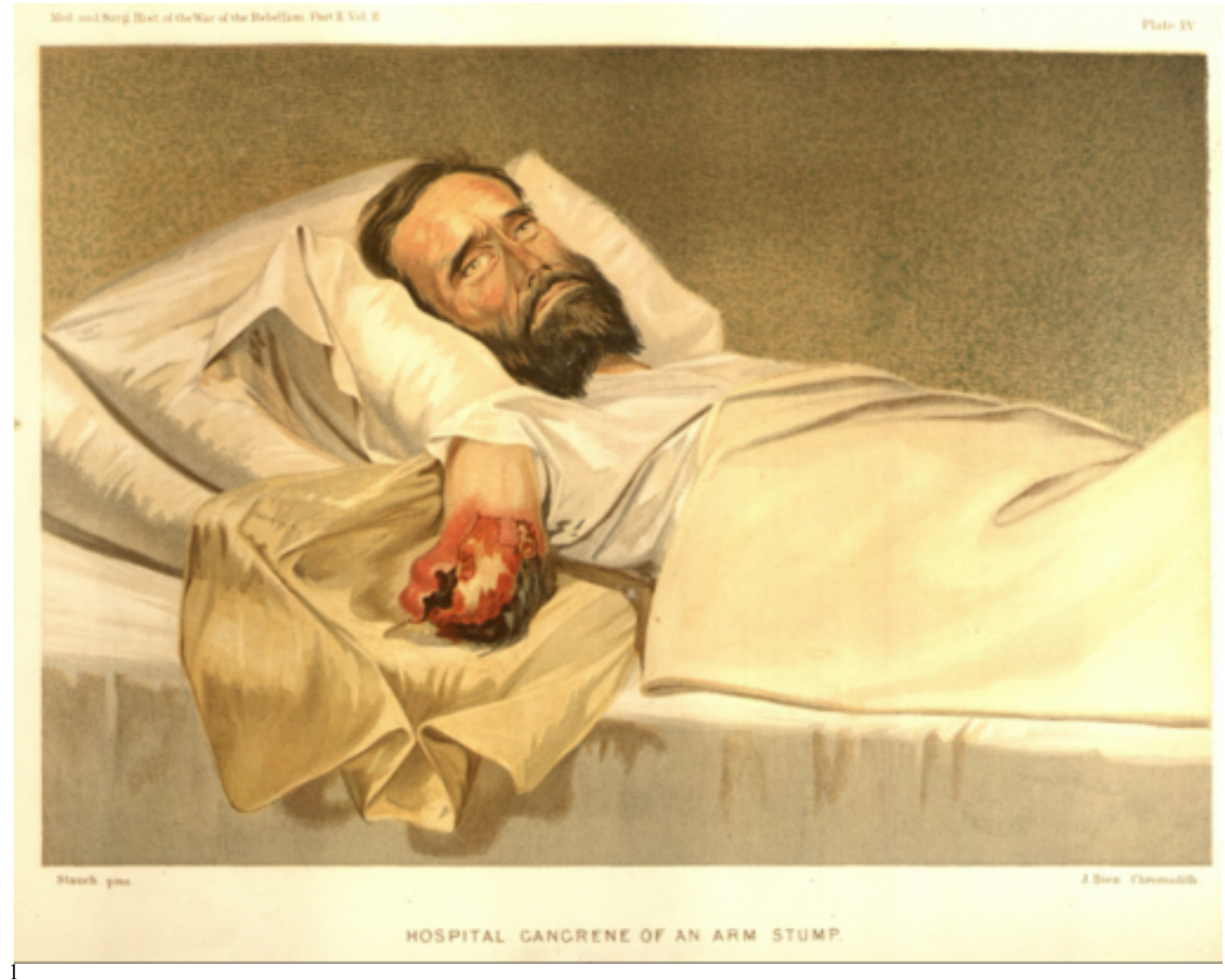

\footnotetext{
${ }^{1}$ Private Milton E. Wallen of Company C, $1^{\text {st }}$ Kentucky Calvary suffers from a gangrenous amputated arm.
} 
By the time of John Pope's rout at Second Manassas, Alfred Bellard was no stranger to the ugliness of war. Reflecting on the conflict years later, Bellard, a private in the $5^{\text {th }}$ New Jersey Infantry, vividly recalled the horrible devastation. As a veteran of the Peninsular Campaign, he bore witness to his fair share of death, disease, and injury all of which he noted in his memoirs. He was not alone in his accounts of wartime tragedy. Post-battle descriptions by medical practitioners, nurses, and reporters also drew attention to grievous injuries and wide-scale suffering. However, for Bellard and his fellow soldiers the elephant of war had long ago been replaced with a jaded sense of curiosity. Bored, and perhaps a bit complacent, with "nothing to do the next morning," Bellard and his companions visited the regimental field hospital to satisfy "a curiosity to see the wounded." The field trip did not disappoint. "The building was filled with wounded, and as I got there, our regimental surgeon was just trying up the arteries and sewing the flaps of flesh together." Their curiosity slaked, Bellard and his cohorts made their way back to camp noting the continuous stream of ambulances along the way. ${ }^{2}$

Not everyone was as nonchalant over scenes of amputation. Adams County, Pennsylvania resident Tillie Pierce, expressed her disgust over the medical treatment of soldiers in the aftermath of Gettysburg. Only fifteen when the battle commenced, she found herself drawn toward the field hospitals near her home. "Gaping upon these [limbs], too often the trophies of the amputating bench, I could have no other feeling than the whole scene was one of cruel butchery." ${ }^{3}$ Whether surgeons were butchers or saviors was a matter of contention all throughout the war as soldiers, nurses, and citizens such as

\footnotetext{
${ }^{2}$ Alfred Bellard, Gone for a Soldier: The Civil War Memoirs of Private Alfred Bellard ed. David Herbert Donald (Boston: Little, Brown and Company, 1991), 144-145.

${ }^{3}$ Matilda (Tillie) Pierce Alleman, quoted in Gregory A. Coco, A Strange and Blighted Land: Gettysburg, the Aftermath of a Battle (Gettysburg: Thomas Publications, 1995), 185.
} 
Pierce wrote sharply about the questionable medical treatments they witnessed. While comments about the callous nature of surgeons were common enough, relatively few recognized their own complicity in the scenes of agony they so graphically described. It was, after all, Pierce herself who felt the urge to visit the field hospitals of Gettysburg to watch the surgeons tend to wounded soldiers. Both Bellard and Pierce stared at the amputation process intently enough to detail the "flaps of flesh" and the "sawing and cutting off of arms and legs." Their eyes fixated on the mutilated flesh, they did not look away, leave the scene, or protest the surgical treatments; absorbed in the moment they simply stared. "I must have become inured to seeing the terrors of battle else I could hardly have gazed upon the scenes now presented," stated Pierce in her memoirs. ${ }^{4}$ It was only after she had the time to filter through all she had witnessed that Pierce could vent her despondence over the images of Gettysburg. Bellard's sojourn to the field hospitals proved to have even more of an impact on him just one year later when his visitations became a prophecy of sorts. Injured in the leg at Chancellorsville he found himself on the receiving end of public stares as he convalesced in a Philadelphia general hospital. As a patient one of his duties was to escort tour groups around the grounds to show them the various buildings, surgical rooms, and recovering soldiers. With just a hint of irony Bellard recognized his own role as one of the exhibits.

What compelled citizens and soldiers to bear additional witness to maimed bodies when the war had already proved its reverence for destruction? Why did citizens flock to hospitals and battlefields to objectify, whether consciously or subconsciously, wounded men? What prompted macabre curiosity and how did it shape their views on the war?

\footnotetext{
${ }^{4}$ Matilda Tillie Pierce Alleman, At Gettysburg, or What a Girl Saw and Heard of the Battle, A True Narrative (New York: W Lake Borland, 1889).
} 
This chapter seeks to explain why gawking at disabled bodies was an indelible part of the conflict and argues that such behavior allowed citizens and soldiers to reconcile the ruination caused by the war through the familiar cultural relationship between spectatorship and display. The behavior went by many names, but whether it was called curiosity seeking, staring, gawking, exhibition, manifestation, or exposition the dynamics remained the same: namely that an interpersonal connection was made between the audience (the starer) and the exhibition (staree), one in which an intense visual exchange created meaning. As Rosemarie Garland-Thomson attests, "Staring [made] things happen between people." 5

In its most basic form staring is a process of information gathering. It is an ocular reaction of the brain's desire to create order and understanding to the illegible or chaotic, a dynamic that, in the case of wounded Civil War soldiers, used injuries as the vehicle for making sense of the war. Put simply, it was the process of seeking out and staring at maimed bodies that allowed men and women to construct meaning from the destruction caused by the war. While injured soldiers themselves could aid this process they were ancillary to the visual stimuli of their wounded bodies. The relationship between the starer and the injury "set into motion an interpersonal relationship, however momentary, that [had] consequences." The consequences of this relationship thereby shaped their overall perception of disability by drawing from both generative and oppressive effects of staring. ${ }^{6}$

So why were soldiers and citizens drawn toward appalling scenes of bodily mutilation? The simple answer is that they were curious. However, when peeling away

\footnotetext{
${ }^{5}$ Rosemarie Garland-Thomson, Staring: How We Look (New York: Oxford University Press, 2009), 33.

${ }^{6}$ Garland-Thomson, Staring, 3. For more on the generative effects of destruction see, Megan Kate Nelson, Ruin Nation: Destruction and the American Civil War (Athens: The University of Georgia Press, 2012).
} 
the layers of this seemingly simplistic answer we find a complex cache of behaviors and motivations that pushed people to be curious. In Rosemarie Garland-Thomson's study, Staring: How We Look she argues that staring is a powerful visual response to what we don't expect to see. The ordinary seldom holds our attention for very long, but the abnormal demands intense scrutiny. It is why we rarely stare at people or situations with which we are already familiar. Staring, in its most basic form, is an ocular quest to know more. If staring is a quest for comprehension then its goal is to order the unruly and to know the strange. ${ }^{7}$

While curiosity, staring, gawking, ogling, and all of its ocular cousins are common cultural behaviors its roots are actually a series of physical and cognitive responses to visual stimuli. Studies show that heart rates increase when staring takes place. Neuroscientists have used cortical EEGs to map the electric oscillations in the cerebral cortex during staring episodes. ${ }^{8}$ The largest impact of staring occurs however, when the brain releases dopamine in response to novel visual events. Dopamine, the same chemical responsible for our sense of pleasure, rushes through the body when the brain registers atypical experiences or satisfies curiosity. In other words, the brain is stimulated when it interacts with the abnormal, even if that abnormality is grotesque in nature. This neurological response helps to explain why soldiers and citizens during the Civil War era sought to satisfy their curiosity by staring at maimed bodies: their brains found pleasure in it. When people stared at wounded men they unknowingly engaged in a neurological process designed to satisfy the nucleus accumbens, or pleasure center, which stemmed from the mind's need to create order from tragic events, such as

\footnotetext{
${ }^{7}$ Garland-Thomson, Staring, 3.

${ }^{8}$ Simon Baron-Cohen, "Mindblindness: An Essay on Autism and "Theory of Mind," Learning,

Development, and Conceptual Change (Cambridge: MIT Press, 1995).
} 
amputations. ${ }^{9}$ As physician Gregory Berns notes, "you may not always like" what you stare at, "but your brain does." 10 This also explains why traffic slows to a crawl when passing an accident, or the urge some people felt to visit ground zero after $9 / 11$, and the inundation of graphic images available online after the Boston Marathon bombings in 2014. As Louisa May Alcott stated in her journal, "I never began a year in a stranger place than this... [I am] alone among strangers, doing painful duties all day long, \& leading a life of constant excitement in this greathouse [hospital] surrounded by 3 or 4 hundred men in all stages of suffering, disease, \& death...I like it."

The intense fascination with oddity is short-lived however, and the dopamine rush recedes as novelty gives way to understanding. Psychologist Ellen Langer found that people stare at what she called, "novel stimuli" as a form of "exploratory behavior.", The motivation for staring is an expedition for information. Those who visited battlefields, hospitals, sanitary fairs, and urban wharves in search of wounded soldiers were drawn by an inexplicable desire to integrate new information into what they already knew, in turn, reducing their uncertainty about the war. Garland-Thomson notes that the act of staring is a contradiction in itself, "the extraordinary excites us; the ordinary assures but bores us. We want surprise, ... [yet we seek] to domesticate the strange sight into something so common as to be unnoticeable." We at once want and do not want to gawk at abnormal or macabre sights. ${ }^{13}$ Therefore hardened soldiers and cast-iron citizens who gave into their curiosity to view wounded men fell into a cycle of macabre

\footnotetext{
${ }^{9}$ The nucleus accumbens is also connected to desire, sex, fear, motivation, depression, and addiction.

${ }^{10}$ Gregory Berns, Satisfaction: The Science of Finding True Fulfillment (New York: Henry Holt, 2005).

${ }^{11}$ Louisa May Alcott, The Journals of Louisa May Alcott ed. Joel Myerson and Daniel Shealy (Boston: Little, Brown and Company, 1989), 113. Union Hotel Hospital Georgetown, D.C., January 1863,

${ }^{12}$ Ellen Langer J. "Stigma, Staring, and Discomfort: A Novel-Stimulus Hypothesis," Journal of Experimental Social Psychology 12 (1976): 451-463 quoted in Rosemarie Garland-Thomson, Staring, 18.

${ }^{13}$ Garland-Thomson, 19.
} 
fascination and ennui in which the visual stimuli, or pleasure, quickly acclimated to the scenes of the battlefield, hospital, or street event, thus causing them to seek out new destructive scenes. Maimed bodies became ordinary and categorical therefore the brain did not desire more information nor draw any more pleasure from them. Medical personnel and volunteers needed their senses to acclimate to post battle scenes to effectively care for soldiers. Volunteering her time with the U.S. Sanitary Commission, Katherine Wormley admitted as much in a letter to her mother. "We who are here... dare not let our minds, much less our imaginations, rest on suffering: while you must rely on your imagination to project you into the state of things here." ${ }^{\text {14 }}$

The effects from spectacle, however, are more than a series of physiological and cognitive responses. Staring is also a platform for the construction of meaning and communication. Much like all impulses, staring has a history that is specific to each culture, which in turn shapes its meaning and practice. ${ }^{15}$ In the Civil War era, the elements of staring, curiosity, and spectacle were imbued with meaning through vast social changes and the response to those changes. The mid nineteenth-century was afflux with a rapidly changing visual landscape. The ever-expanding city, mechanization, industrialization, advertisement, signage, innovations in technology and transportation, to say nothing of the influx of strange new languages, customs, and faces, left an indelible impact how people perceived the world around them. Anxieties over unrestrained modernity made some wonder if their own bodies could suddenly transform. In 1860, the New York Times printed a story about a young man whose arm became so badly damaged

\footnotetext{
${ }^{14}$ Katherine Wormley to her mother, May 26,1862, in The Other Side of War with the Army of the Potomac: Letters from the Headquarters of the United States Sanitary Commission during the Peninsular Campaign in Virginia in 1862 (Boston: Ticknor, 1889), 99.

${ }^{15}$ Garland-Thomson, 19.
} 
after getting caught in some machinery that immediate amputation was necessary. Later that night the boy insisted he could feel bouts of pain shooting through his cramped hand. After some instance he convinced hospital officials to dig up the hand, whereupon the attendants discovered that the hand was in a "doubled up" position. Straightening the appendage they placed it in a tomb rather than re-internment, so as to prevent the boy from feeling the numbing effects of the cold ground. ${ }^{16}$

These kinds of stories were a testament to fears over the uncertainty of modernization and its impact on the human body. Industrial accidents, sensationalized stories of murder and torture as well as local papers that detailed the wounds of loved ones and neighbors made the threat of sudden abnormality all too present. Returning to our previous examples at the beginning of the chapter we can see how the effects of staring mingled with societal anxieties. When Alfred Bellard visited the field hospital to stare at his wounded comrades he engaged in a dynamic struggle in which he sought to alleviate his anxieties concerning the possibility of his own transformation. Staring reaffirmed his own normalcy, if only for the moment, in an increasingly destructive war. For Tillie Piece, "gaping" provided a stabilizing force for a young girl who watched helplessly as the bucolic hamlet of Gettysburg quite literally transformed into a "strange and blighted land" overnight. Unlike Bellard however, Pierce's stares generated a sympathetic bond between herself and those touched by the carnage. By volunteering as a nurse in the weeks following the battle she aided a return to normalcy for both the wounded soldiers and her home. ${ }^{17}$

\footnotetext{
16 "Sympathy of the Body with an Amputated Member," New York Times July 17, 1860.

${ }^{17}$ Nelson, Ruin Nation; Coco, A Strange and Blighted Land; Garland-Thomson, Staring, 4.
} 


\section{Moving Means Seeing}

Curiosities had been a part of the American cultural landscape for generations. By the time of the Civil War, the north already had a well-developed system for using deformed and disabled bodies in public displays. Men, women, and children attended events in increasing numbers that placed abnormal bodies in the center of various forms of entertainment. On any given day one could attend a number of dime museums, anatomical museums, surgical theatres, tavern lectures, traveling fairs, and circuses to engage with extraordinary bodies. Curiosity, along with ingenious marketing campaigns, ensured the steady growth of these businesses, despite objections from Victorian moralists. During the war these types of entertainments only increased as museums, sanitary fairs and hospitals tapped into this well-established cultural trend. Meanwhile citizens found ways to satisfy their curiosity by traveling to battle sights, touring convalescence camps, and volunteering at general hospitals, The mid nineteenth-century transportation revolution aided this growth in important ways. Turnpikes, canals, steamboats, and railroads allowed men and women to travel vast distances with little difficulty. The sheer motion of Americans ensured that curiosity seekers could and would take in the sights of the war. As Alexis de Tocqueville stated in his widely read Democracy in America, when a man has time for leisure and entertainment "his restless curiosity goes with him traveling up and down the vast territories of the United States." ${ }^{\text {"18 }}$

\section{Curious Bodies: Battlefield Gawkers and the Wounded}

John H. Brinton, brigadier surgeon and cousin to George B. McClellan, was shocked to see the bodily damage caused by an exploding shell. Though Brinton had seen his fair

\footnotetext{
${ }^{18}$ Alexis de Tocqueville, Democracy in America (1835).
} 
share of injuries throughout his medical career, the destruction caused by the shell left a lasting impression on the young surgeon. The explosion, which tore "the whole of the skin and muscles of the back from the nape of the neck to the thighs" of a young soldier, was a testament to the horrors of warfare. Almost thirty years later Brinton could still recall the scene in visceral detail. "Both sides of the spine had been torn away as if the tissues had been scooped out by a clean-cutting curved instrument. The surfaces were raw and bleeding, and the sight was a horrible one, and one which I have never forgotten."

Civil War era letters and memoirs are full of graphic images such as the one Brinton portrayed. Yet, despite the abundance of documents produced at the time, men and women lamented their inability to translate the images of war into the written word. This "impotence of language," Michael DeGruccio argues, "failed to express what inhered in the material world." The use of language seemed vapid, leading many letter writers to simply abandon their efforts to describe their experiences. ${ }^{20}$ An infantryman of the $15^{\text {th }}$ New Jersey recalled the horrors of transporting wounded men to the field hospital. "Limbs were thrown in piles outside the hospital tents...there were men with both legs gone; men shot through the lungs; men with bullets in their brain; men with their bowels protruding." It was a scene, "no pen could describe" and "no tongue however eloquent could portray."21 It was clear to many that the war had to be seen, smelled, felt, and tasted.

\footnotetext{
${ }^{19}$ John H. Brinton, Personal Memoirs of John H. Brinton: Civil War Surgeon, 1861-1865 (Carbondale: Southern Illinois University Press, 1996), 75.

${ }^{20}$ Michael DeGruccio, "Letting the War Slip Through Our Hands: Material Culture and the Weakness of Words in the Civil War Era," in Weirding the War: Stories from the Civil War's Ragged Edges ed. Stephen Berry (Athens: The University of Georgia Press, 2011), 17.

${ }^{21}$ Coco, 180; Earl Hess, The Union Soldier in Battle: Enduring the Ordeal of Combat (Lawrence:

University of Kansas Press, 1997), 32.
} 
Whether these scenes played out in battlefields, hospitals, or repeated in letters and diaries, the dead and maimed bodies took an obvious toll on their witness. When Major C. H. Weygant of the $124^{\text {th }}$ New York searched for some of his wounded men after the battle of Gettysburg, he experienced some of the most terrifying images he ever imagined. Under the cover of darkness Weygant picked his way through "acres of mangled bleeding human forms" in a large grove of trees behind Union lines. During his search one wounded man "sprang to his feet, shook in front of me a bloody bandage he had just torn from a dreadful, gaping wound in his breast, and uttered a hideous, laughing shriek." Weygant was able to break away from the deranged man but not before "hot blood spurt[ed] from his wound" onto Weygant's face. After the incident he abandoned his mission "I could endure no more, wheeling about, hurried over the wounded and dying to the open field again.” Though Major Weygant was a veteran of numerous conflicts he could not relegate himself to the tortures of post-battle scenes. His failed errand of mercy weighed on him for years after the war. "I was heartily ashamed of the weakness which had caused me to turn back., ${ }^{22}$

Yet, time and time again soldiers and citizens found themselves drawn toward scenes of carnage by an overpowering sense of curiosity. Letters, diaries, and newspaper articles were filled with excerpts of men and women's desire to gaze upon suffering soldiers. "To see the wounded coming in from the front made a man feel curious," wrote Joseph Kauffman after the Battle of McDowell. ${ }^{23}$ If staring was the process by which the war could be contextualized, curiosity was the conduit that urged one toward action. At its core curiosity elicited amazement by breaking the rules of the ordinary. Like

\footnotetext{
${ }^{22}$ Coco, 182.

${ }^{23}$ Joseph Kauffman, Diary, May 8, 1862. . Southern Historical Collection, The University of North Carolina, Chapel Hill.
} 
staring, curiosity focused on the unusual and took its power from the extraordinary, inspiring, wondrous, surprising, monstrous, macabre, and the exceptional. It is why the sights and sounds of amputation, mangled stumps, and streams of red blood caught the attention of soldiers and citizens alike. In short, disability was wondrous. ${ }^{24}$ If, as Walt Whitman attested, "real war" could never be in the history books then citizens would find a way to authenticate the experience of war, or at least their version of it. Disabled soldiers provided this link. Their injuries served as a bridge between the fantasy of conflict and the actual travesty of war. Not only did gaping upon wounds provide them with the experience of war, it also laid the foundation for empathetic forms of philanthropy. Volunteering as a nurse, for instance, provided a level of intimacy and perception that would have been impossible with sewing circles, fundraising campaigns, or letter writing.

Even high-ranking military officials were not immune to the effects of curiosity and staring. Just one day after the Union victory at Gettysburg, wounded bodies littered the fields in and around Adams County. Newspapers commented on the "disgusting atmosphere" and the "polluted" air that engulfed the area, leaving some to wonder how human beings could continue to live in the small town. Yet, the vile scents and sounds attracted the very same military officers who had a hand in creating them in the first place. As one soldier rejoined, the "scenes were horrid and the unattractive employment particular to those people who are spending their first day on a rough sea, was popular among military visitors gratifying morbid curiosity." ${ }^{25}$ Carl Schurz, division commander of the XI Corps, walked amid a the field hospitals listening to the "moaning and wailing

\footnotetext{
${ }^{24}$ Rosemarie Garland-Thomson, review of Monsters: Human Freaks in America's Gilded Age ed. Michael Mitchell and Extraordinary Exhibitions, Ricky Jay.

${ }^{25}$ Coco, 11 .
} 
of human beings," taking note of the surgeons he continued, "their sleeves rolled up to the elbows, their bare arms as well as their linen aprons smeared with blood...all around them pools of blood and amputated arms or legs in heaps, sometimes more than a manhigh. ${ }^{26}$ Curiosity it seemed, touched everyone.

Battlefield relics offered visitors tangible evidence to the havoc around them; proof that what their eyes beheld was real. These trophies not only authenticated the experience of war for soldiers and citizens, they could also collapse time and space when touched, making them valuable mementoes for decades after the war.

A recent essay by Michael DeGruccio argued that material objects captured a wide range of conflicting sentiments over wartime excursions, more so than words. Many recognized that language failed to adequately capture the anguish and desolation witnessed by battlefield visitors. The "abundant yet elusive" nature of words effectively "watered down" making them an ineffective and superficial tool for interpreting the war. Imbued with intense meaning, material objects needed no description or explanation. They were simple yet ineffable, conduits to powerful experiences. Surgeon John Bennitt sought such keepsakes during his post aboard the Woodside in early 1863. When he arrived at Fort Donaldson almost a year after its capture Bennitt longed to send his wife a keepsake from the battle. Long before his arrival news of Grant's victory proliferated in newspapers throughout the north. Though his wife was familiar with the events surrounding the fight, Bennitt was adamant that she was unable to imagine the chaos that remained. "The newspaper accounts of the matter may be fuller than I have time to write, but to have any just appreciation of the matter one must see the havoc made here." The first thing he did upon his arrival was to tour the battlefield "I have spent the day going

${ }^{26}$ Carl Shurz, “The Battle of Gettysburg,” McClure's Magazine. Vol. XXIX (May to October 1907), 285. 
over the battleground, - for it was all within a half mile of where I now am." As a respected surgeon Bennitt would have already seen his fair share of suffering on the operation table, yet it was not until he toured the battlefield that he felt an "appreciation" of the "havoc" of war. Two weeks later Bennitt was still unable to procure a memento to send his wife, "I have not much time to look for curiosities...but will try to send you something when practical." Even esteemed members of the Sanitary Commission, a group whose very existence centered on humanitarian aid, felt the irresistible draw toward battlefield relics. Frederick Law Olmstead himself almost missed his transportation boat because he had been "relic hunting on the battlefield" outside Williamsburg. ${ }^{27}$

Collecting battlefield tokens was not a new phenomenon during the Civil War, nor was it a distinctly American endeavor. Wealthy families who partook in the Grand Tours of Europe often made time to visit historical sites and battlefields reminiscent of the European wars. John W. Corson, a reputable physician from New York, was one such tourist. The goal of his 1840 s tour was to gather information on popular tourist sites then publish those findings for those who could not afford a trek across Europe. The sensations one felt while touring buildings and battlefields was paramount to his work. After visiting the famous Hotel de Invalides in Paris and the Hospital of Salpetriere he made his way to the battlegrounds of Waterloo. In his book Corson testified to his "immense zeal" for the visiting site, going into depth about the "fantasies he built up" in

\footnotetext{
${ }^{27}$ Michael DeGruccio, "Letting the War Slip Through Our Hands," 17, 23; John Bennitt, I Hope to do my Country Service: The Civil War Letters of John Bennitt, M.D., Surgeon, $19^{\text {th }}$ Michigan Infantry ed. Robert Beasecker. (Detroit: Wayne State University Press, 2005), 99, 159; Cyrus Bacon. May 12 1862, Cyrus Bacon Papers, (USAHEC);. For more on relic hunting and trafficking by Northern and Southern soldiers see Joan Cashin, "Trophies of War: Material Culture in the Civil War," The Journal of the Civil War Era 1, (September 2011): 339-367.
} 
his mind as he imagined the French columns of soldiers on the Hougoumont. As he toured the field however, his romanticized idealism soon shifted toward dreadfulness.

\begin{abstract}
The day was wet and dreary, and the field that, in imagination, I had just peopled with contending hosts as silent as the grave. There came over me a feeling of unmingled sadness. You trod as though the very turf beneath your feet had been a "soldier's sepulcher." The guide, who had been employed in taking care of the wounded, gave a fearful account of the cries and suffering as, to use his comparison, they lay helpless and bleeding, like maimed and slaughtered sheep. No wife or mother came to moisten their parched lips, or catch their last whisper; but their death dreams was of their brethren, who, they scarcely knew why, were piercing each other's breast above them, and of the smoke and din as of a conflict of demons. The past pang was perhaps given by the crushing wheel of artillery, or their yet living faces were mangled by the hoof of the maddened courser. I never had such a consciousness of the sinful cruelty of war. Every memorial was of destruction. Little innocent looking children came up and offered bullets and bits of broken armor... I looked upon the fresh furrows in one part of the field, and discovered fragments of human bones mingled with the earth; and the guide, learning that I was a physician, and thinking to gratify me, offered me a skull. $^{28}$
\end{abstract}

Carson was not alone in his enthusiasm for war relics. In their zeal to collect tokens, citizens lost sight of common sense. A businessman traveling through Yorktown, Virginia during the Peninsula Campaign wanted to "see the sights before returning to the North." In the distance he saw what he believed to be an expired cannonball but what actually turned out to be a spherical case shot. As he neared it the case shot exploded. "It frightened him most out of his wits. He wanted the shell to add to his collection of war curiosities. ${ }^{29}$ Fortunately he did not suffer any injuries from the explosion. Lieutenant Lyman Richardson shared a similar story about a cleric from Michigan. The religious man hoped to "look around a bit" close to the siege lines at Vicksburg. "At dusk I took him down into the trenches... up to the head of our sap... which is only about

\footnotetext{
${ }^{28}$ John W. Corson, M.D., Loiterings in Europe: Sketches of Travel in France, Belgium, Switzerland, Italy, Australia, Prussia, Great Britain, and Ireland (New York: Harper and Brothers Publisher, 1848), 81-82.

${ }^{29}$ Heyward Emmell. The Civil War Journal of Private Heyward Emmell: Ambulance and Infantry Corps: A Very Disagreeable War, ed. Jim Malcolm (Madison: Fairleigh Dickinson University Press, 2011), April 30 $1862,19$.
} 
fifty feet from the enemy's works. He heard two or three bullets whiz over our head...and said very feelingly this is a real war. He will have some huge stories to tell when he gets back to Pontiac."30

Curiosity did not always lead to collecting relics. Many of the soldiers and citizens simply stared at the transformed bodies and landscape. Ironically, for some, the image of wounded soldiers was exponentially worse than viewing the dead. While dead bodies were traumatic in their own right, their faces contorted in a death mask, the eerie stillness of their features frozen in place, they were imbued with an essence of finality. They were "silent sleepers in the city of the dead, unconscious to the terrible conflict going on about them. ${ }^{31}$ Injured men however, were a canvas of constantly changing sights, sounds, and smells. "May God spare me from ever witnessing another such scene...I will never again go over a battle-field from mere curiosity," wrote Edmund Brown of the $27^{\text {th }}$ Indiana Volunteer Infantry. ${ }^{32}$

The act of gazing at the wounded and suffering had been an important part of northern culture for decades. Therefore it is not surprising to find that, apart from soldiers, civilians used the values and sentiments associated with suffering to legitimize their curiosity of the disabled. As Frances Clarke noted, the concept of suffering had a profound and complex impact on public perception. Influential Scottish philosophers like David Hume argued that powerful links existed between the concepts of suffering and freedom. Northerners felt "an innate moral sense that could orient human beings toward

\footnotetext{
${ }^{30}$ Earl Hess, "Tell me What the Sensations Are," in Union Soldiers and the Northern Home Front ed. Paul Cimbala and Randall Miller (New York: Fordham University, 2002),139.

${ }^{31}$ Jabob Hoke, Historical Reminiscences of the War, or, Incidents Which Transpired In and About Chambersburg During the War of the Rebellion (Chambersburg, PA: M.A. Foltz, Printer and Publisher, 1884), 172.

${ }^{32}$ Edmund Brown, The Twenty-Seventh Indiana Volunteer Infantry in the War of the Rebellion 1861 to 1865 (Gaithsburg, Md.: Butternut Press, 1899), 394-95.
} 
compassion and benevolence if only they practiced sympathizing with those in distress." The freedom afforded privileged whites in the antebellum period linked their sympathy for the suffering with pretensions of superiority, most notably in the areas of humanitarianism and sentimentalism. These notions were reinforced in Protestant cultural rhetoric. Ministers, sentimental novelists, pamphlets, ephemera, lectures, and reform organizations combined to idealize victimhood and moralize those who offered economic, literary, or personal aid. To quote Clarke, "exemplary suffering [was used] as a form of social power." Additionally, to engage with the suffering was to act as a safeguard against the impious temptations of industrializing cities. Clarke's work on suffering, then, offers valuable insight into Rosemarie Garland-Thomson's work on staring. Taken together we see that compassion operated as a byproduct of sympathy even while sympathetic emotion was aroused through the act of staring. The intending result among northern citizens was just as complex and varied, leading some toward benevolent activities such as volunteerism or fundraising. Others demonstrated a penchant for the boorish by traveling to battlefields to gawk at wounded men. One thing is certain though, the sight of hundreds or even thousands of wounded soldiers proved to be an enticing allure that many could not ignore. Whether the stares of these suffering soldiers was generative or oppressive in nature, they all helped citizens come to grips with the turmoil of war. ${ }^{33}$

Civil War accounts are full of examples of citizens coming to battlefields to see the destruction of war first hand. Popular stories tell of Washingtonians picnicking on hills of Manassas hoping to catch a glimpse of the spectacle. Reporters from hundreds of

\footnotetext{
${ }^{33}$ Frances Clarke, War Stories: Suffering and Sacrifice in the Civil War North (Chicago: University of Chicago Press, 2011), 19; Garland-Thomson, Staring; Alan Trachtenberg, The Incorporation of America: Culture and Society in the Gilded Age (New York: Hill\& Wang, 1982).
} 
large cities and small villages, in addition to a number of foreign correspondents, filled newspapers with exploits from the warfront. Photographers like Matthew Brady, Alexander Gardner, and George Cook followed the armies in an attempt to capture the images of war for an eager audience back home. In every major battle there existed an excess of individuals employed in the documentation of the war. Following on the heels of these commentators, or perhaps because of them, came a flood of civilians whose main purpose was to experience the war for themselves. The most egregious examples came in the aftermath of Gettysburg. Gettysburg served as an opportunity for the northern public to witness in person what they had been reading about for two years. Advances in transportation throughout the antebellum period made travel relatively easy and inexpensive. Most of the citizens who went to Gettysburg did so for purely altruistic reasons. Some went in search of loved ones who had been away from home for far too long. Others offered aid by way of foodstuffs, clothing, and transportation to medical centers. Still more felt the humanitarian influences of their Protestant upbringing and offered themselves up as volunteers. However, there were some that were drawn simply for the desire to see the ruination that they could only image in their mind's eye.

Liberty Hollinger took note of the unfamiliar faces flooding into town immediately after the battle. "The town began to fill with friends and strangers, some intent on satisfying their curiosity." In the wake of battle the Union left behind a veritable army of military officials, medical personnel, and nurses who took residence in just about any house, hotel, barn, or tent that could hold them, leaving precious little room for tourists. Visitors felt no compunction at knocking on a stranger's door and pretending to be a distant relative. Family friends and acquaintances, "who were 
normally always welcome at [the] house," were often not what they appeared to be. Hollinger was saddened to learn that some visitors claimed acquaintance in order to have a "stopping place." The throng of sightseers only increased as the weeks wore on. Some "turned out to be in deadly earnest in their searches for a friend or relative who had been hurt or killed in the fighting. But always intermixed with these sad cases, and usually outnumbering them unfortunately, were the onlookers whose main goal was to fulfill a desire to stand and behold and touch the macabre in all of its most bizarre forms. ${ }^{.34}$ As Mary A. Newcomb candidly wrote, "we often read of war and say it is sad, but one must see the battle-field and be with the wounded and dead to have an adequate idea of war." ${ }^{35}$

Civilian gawkers who visited the town of Gettysburg soon made self-guided tours of the battlefields and field hospitals. Cyrus Bacon, a surgeon in the 7th Michigan Volunteers had to spend precious moments away from his patients to deal with those who treated wounded soldiers as spectacles. "Thousands visited the battlefield yet, for days I did not see the first act of charity from the people...the people seem to consider us lawful prizes, and are not only extortionate but give us little real sympathy." Soldiers were appalled at the citizens who desired only to gaze upon wounded men in the field and in hospitals. Private Frank Haskell vented his frustration concerning the impertinent trespassing on hallowed ground. "Numbers of civilian boys, and some girls even, curiously loitering about the field and their faces show not sadness or horror, but only staring wonder or smirking curiosity." Colonel Wainwright of the First Corps Artillery expressed similar sentiments. "Gettysburg may hereafter be classic ground, but its inhabitants have damned themselves with a disgrace that can never be washed out...

\footnotetext{
${ }^{34}$ Coco, $7-8$.

${ }^{35}$ Mary A Newcomb, Four Years of Personal Reminiscences of the War (Chicago: H.S. Mills, 1893), vi.
} 
Hundreds from the county around, too, came down in their waggons [sic] to see the sights, to stroll over the ground, and gaze and gape at the dead and wounded. But not one lifted a finger to help the tired soldiers remove the one or bury the other." ${ }^{36}$

Things got so bad that newspapers began to publish articles pleading with tourists to stay away from the battlefield. Reporters sought to shame visitors away by linking gawking with the commercialization of abnormal bodies in museums and traveling fairs. "A word of well meant advice. Let no one come to this place for the simple purpose of seeing. To come here, merely to look at the wounded and dying, exhibits a most vitiated and disgusting taste. Besides, every visitor is a consumer, and adds to the misery of the sick, by subtracting from the means that should be given exclusively to them. Let all that come. Come with store for the sick, and ready to work for them, but let all mere sightseers stay at home." The museum effect was even more pronounced for Ambulance Corps staff member Heyward Emmell. When his transport camped for the night at Taneytown local sightseers treated the event as if they were enroute to Barnum's American Museum. "We all take a bath in a little creek which runs near where we are encamped but hardly have a chance as the whole population of the place came to see us, as if we were a traveling museum." By treating injured soldiers as exhibition pieces, gawkers drew upon familiar patterns of audience and display found in popularization of abnormal bodies throughout entertainment venues in the north. ${ }^{37}$

\section{To Mingle Among the Wounded: Field and General Hospitals}

\footnotetext{
${ }^{36}$ Frank A. Haskell, The Battle of Gettysburg, ed. Bruce Catton (Boston: Houghton Mifflin, 1958), 147-48, 154; Coco, 251.

${ }^{37}$ Coco, 169; Emmell, June 29,1863.
} 
Hospitals were the most practical spaces to view injured soldiers. The high volume of sick and wounded men, over worked medical staff, the tide of employees, and the general disarray provided the perfect forum for spectators. This was especially true in field hospitals when every minute away from a soldier could result in death. As such, observers could expect to move about with relative freedom, the shroud of anonymity, or even disregard, provided an opportunity to stare for long periods of time. Beholden to the general landscape surrounding battle sites, field hospitals were hastily erected and could be found in residential homes, shops, warehouses, barns, tents, or even a copse of trees. It was here that the most egregious injuries were open to public scrutiny. Surgical procedures such as amputations, probing for shrapnel, hasty facial reconstruction, and the application of tourniquets provided much visual stimuli for the curious. Field hospitals also provided the most visceral images to onlookers; and commentators wrote graphically about the scenes of carnage they witnessed. No matter how gruesome the spectacle, visitors stood transfixed and absorbed the cacophony of sights, sounds, and scents. Stories about heaps of dismembered limbs pervaded letters home. Rufus Meade of the $5^{\text {th }}$ Connecticut observed insects "flying around in swarms and maggots crawling in wounds. ${ }^{38}$ John Foster, who accompanied a group of volunteers from his church arrived at the Gettysburg field hospitals nearly a week after the battle. "In some cases legs and arms were shot away so closely to the socket that it was impossible to gather up the cords, and the hurts were necessarily cauterized or left to fester and eat away the life." ${ }^{\prime 39}$ The novel sights offered by field hospitals proved to be too alluring for most, even those

\footnotetext{
${ }^{38}$ Earl Hess, The Union Soldier in Battle, 33.

${ }^{39}$ Earl Hess, "Tell me What the Sensations Are," 131.
} 
with purely selfless intentions. For those who took the time to look, field hospitals were ocular cornucopia of stimuli.

Field hospitals served many functions. They were sites for locating loved ones, finding missing comrades, and centers for volunteerism all at once. At times field hospitals were so chaotic it was hard to tell its primary purpose was medical care. More than one person commented on the raucous nature. Some caretakers found it difficult to tend to patients amidst the clamor and confusion. When Mary Kelly traveled to the warfront upon hearing of her husband's injury she was surprised at the sheer activity surrounding convalescent areas. "There are people here from every direction come to look after their friends," she wrote home. "This is the noisiest place ever any body was in. ${ }^{\circ 0}$ Indeed, it seemed as if the sounds of the field hospital could be just as gut wrenching as the images. John Foster, a volunteer with the U.S. Christian Commission commented, "During every minute of fifteen hours every day some sufferer was on the table. Groans, shrieks, and curses constantly filled the air, the sound of the knife and crash of the saw blending continuously with the din of agony." ${ }^{, 41}$ Following White Oak Swamp, Captain Edward A. Acton wrote of the screams, "Doctor! Doctor! Oh! God where is the Doctor? I would hear a boyish voice calling in a sobbing and pleading tone for something or somebody...I would hear weeping voices bewailing their fate and begging for relief... What was more terrible than all many were blaspheming and cursing most terribly." ${ }^{42}$ The sounds of war, it seemed, could be just as harsh as the images.

The transient nature of field hospitals meant that local citizens had a limited amount of time to see the wounded. The novelty of sights went beyond the macabre,

\footnotetext{
${ }^{40}$ Mary Kelly to “Dear Friend," April 4,1862, James R. Kelly Letters, Gilder Lehrman Institute.

${ }^{41}$ Coco, 179.

42 Robert Goldwaithe Carter, Four Brothers in Blue (Austin, 1978), 308.
} 
Antietam and Gettysburg provided opportunities to see the famed Army of Northern Virginia. Apart from observation towers or excursion around the prison camps at Elmira and Johnson's Island, northern citizens rarely found occasion to see rebels. ${ }^{43}$ The exploits surrounding southern soldiers filled newspapers all throughout the war. The embarrassment of Union armies in the Shenandoah Valley in 1862, by "Stonewall Jackson," along with the dashing victories by R.E. Lee led some to wonder who, or what, these fighters were. While working with the U.S. Sanitary Commission Georgeanna Woosley experienced one such curious tourist. Perhaps believing that the very act of secession could have a transformative effect on the body, one Adams County resident snuck his way into a field hospital. "One of this kind came creeping into our camp three weeks after the battle. He lived five miles away only from the town, and had never seen a rebel. Boys,' we said, marching him into the tent which happened to be full of rebels...here's a man who never saw a rebel in his life and wants to look at you." ${ }^{, 44} \mathrm{We}$ will never know what the local expected to see, however it is clear that this particular Pennsylvanian believed that a sense of "otherness" existed among southern soldiers.

Soldiers were often appalled at the citizens who desired only to gaze upon wounded men in the field and in hospitals. One Massachusetts man who was wounded during the battle of Antietam was affronted by the swarms of tourists attracted to the field hospital hoping to "gratify their morbid sense of curiosity." Sergeant Jonathan Stowe, Company G, of the Fifteenth Massachusetts complained, "men come in and stare at us but detailed men clear out \& leave us. How piteously they beg for water. People come in

\footnotetext{
${ }^{43}$ For more on the exhibitionism surrounding prison camps see Michael P. Gray, The Business of Captivity: Elmira and its Civil War Prison (Kent: Kent State Press, 2001) and "Captivating Captives: An Excursion to Johnson's Island Civil War Prison," Union Heartland: The Midwestern Home Front during the Civil War, ed. Ginette Aley (Carbondale: Southern Illinois Press, 2013).

${ }^{44}$ Coco, 11 .
} 
from all parts of the country. Stare at us but do not find time to do anything.. ${ }^{45}$ Yet, the sights and sounds of suffering soldiers elicited feelings of compassion, patriotism, sorrow, disgust, or even detachment. Regardless of the emotive response however, spectators walked way with a stronger sense of themselves and their role in the war. "None but those who have visited the battle field can have any idea of the sight it presented," wrote Jacob Kiester to his father. It was not until Harriett Whetten worked with wounded men that she felt she understood the war. "Everything is so strange that nothing is strange, and it seems quite natural to me to be near the front lines of the grand army." After dressing one man's leg wound she reflected on the mental and emotional fortitude she recently developed. "A fortnight ago I never could have believed I could do these things." Whetten's experience demonstrates the ways in which the destruction of Civil War bodies had a generative effect by advocating sentiments of empowerment and increased volunteerism. ${ }^{46}$

While moving through Fairfax Station in 1862, Alfred Bellard of the $5^{\text {th }}$ New Jersey took advantage of a halt in the march to watch surgeons operate on wounded men who were to be sent to Alexandria by train to convalesce in general hospitals. He made a mental note of a soldier lying on the makeshift operating table, "One of them had his leg cut off above the knee... The stump looked like a piece of raw beef. The other man had a part of his foot taken off. Neither seemed to be under the influence of chloroform, but were held down by some four men, while nothing but a groan escaped them as the

\footnotetext{
${ }^{45}$ Coco. 11; John W. Schildt, Antietam Hospitals (Chewsville, Md.: Antietam Publications, 1987),14.

${ }^{46}$ Jacob S. Kiester to Father, May 9, 1862, Jacob S. Kiester Papers, Civil War Times Illustrated Collection USAMHI; Harriet Douglas Whetten to Hexie, May 19, 1862, quoted in Earl Hess, "Tell me What the Sensations Are," 131-32.
} 
operation proceeded." ${ }^{47}$ The sight of amputation only seemed to draw more of Bellard's focus. As he continued to tour the field hospitals he absorbed as much of the suffering as possible. "In the afternoon I went over to the corps field hospital, where the doctors were busy in probing for balls, binding up wounds, and in cutting off arms and legs, a pile of which lay under the table. One drummer boy was brought in to be operated upon, who had both hands shattered by the explosion of a gun barrel." Not only did Bellard commit these images to memory but he went on to sketch a number of the scenes he witnessed. ${ }^{48}$

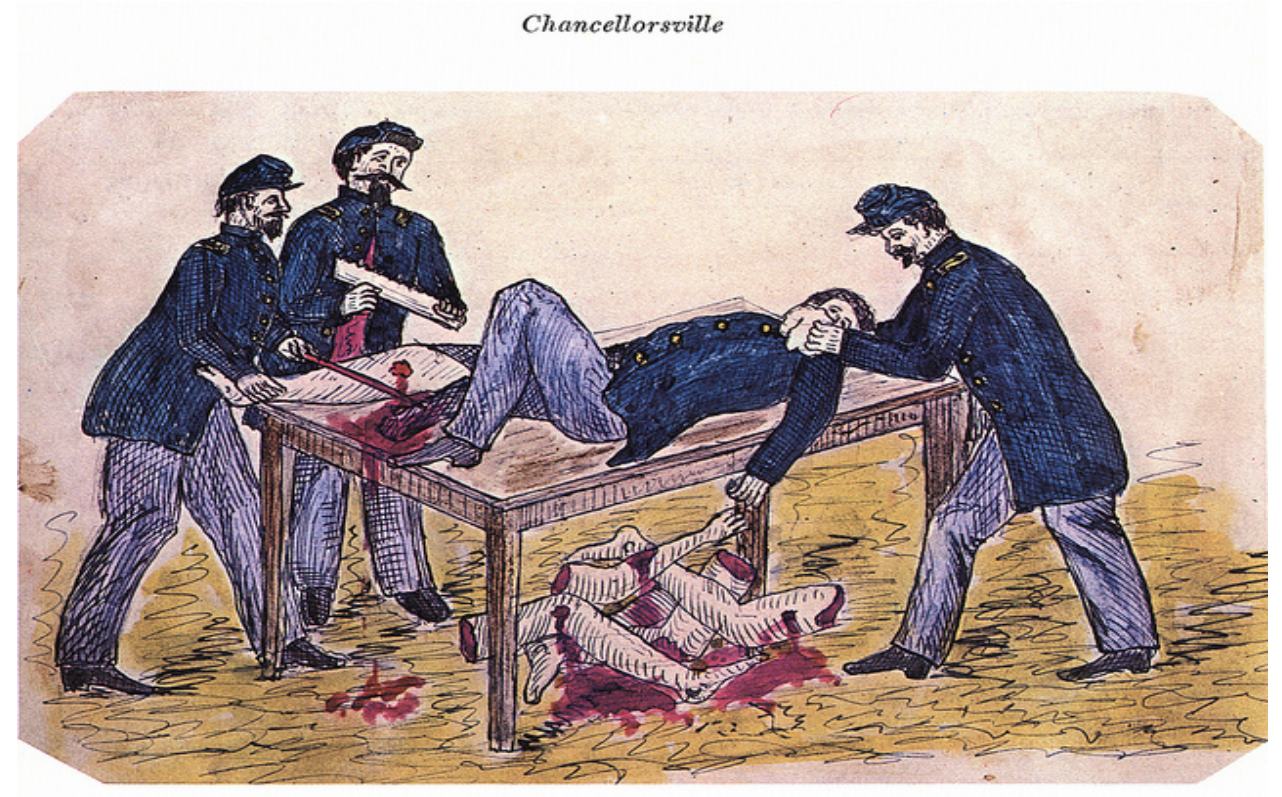

The doctors were busy in probing for balls, binding up wounds, and in cutting off arms and legs, a pile of which lay under the table

\footnotetext{
${ }^{47}$ Alfred Bellard, 146. It is doubtful that the soldiers were not under any kind of anesthetic during the amputation, especially since the patients made no sounds. Over $95 \%$ of solders were under the influence of chloroform or ether during amputations.

${ }^{48}$ Alfred Bellard, 213.
} 


\section{An artileryman who had one leg taken completely off at the knee}

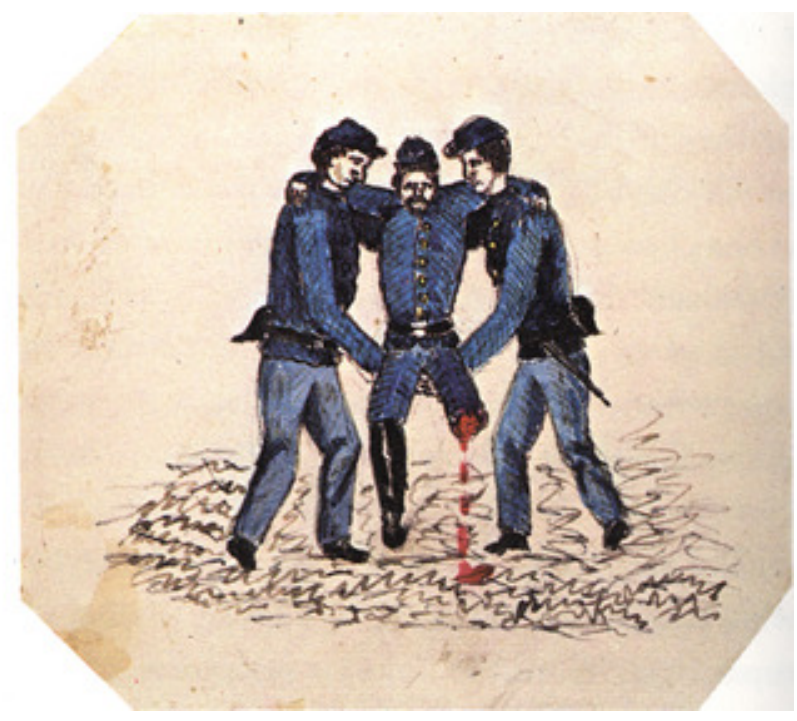

As fate would have it Bellard suffered a leg injury of his own at the Battle of Chancellorsville. He spent the next few months convalescing at Citizen's Volunteer Hospital in Philadelphia until he was healthy enough to earn his keep as a guard at the asylum. ${ }^{49}$ It was not long before he noticed the large number of citizens who visited the hospital. Military hospitals in places like Washington D.C., Philadelphia, New York, Boston, and Providence became popular centers of activity during the war as citizens from the surrounding area flocked to see wounded soldiers. General Hospitals provided citizens with an opportunity to witness the devastating effects of war while engaging in humanitarian efforts. For those who could not travel to the warfront military hospitals offered a way to connect with the realities of war. The motivations for visiting these hospitals were ambiguous at best. Some went to the hospitals in the hopes of locating loved ones while others wished to volunteer their time and resources. Of course not all men and women who visited hospitals did so for purely altruistic reasons. The opportunity to gaze at wounded soldiers proved to be an irresistible, if not a socially

\footnotetext{
${ }^{49}$ It was customary for patients to work in military hospitals early in the war as nurses, guards, custodians, cooks, laundresses, maintenance personnel, and gardeners as a means of keeping costs down.
} 
lucrative, endeavor. Regardless of their motivation all of the men and women who visited these hospitals took part in the growing discourse surrounding disabled and diseased soldiers. To the public who toured urban infirmaries, the stories of ruination need not exist only in newspapers and letters; soldiers brought it with them to their hospital beds.

Visitation numbers at Citizen's Volunteer Hospital were so high that the administrators were forced to set up walking tours for the public. Dominated mostly by women these tours showed citizens the various attractions of the facility. Hospital wards, examination rooms, surgical theaters, recreation areas, and convalescent soldiers were all part of the excursion. Even the guards themselves became objects of attraction as chaperones for female tourists. "A squadron of men had been detailed for the purpose of escorting [the tourists] around and showing them the various points of interest...I declined the honor, in favor of a gentleman who was more of a ladies' man than myself." ${ }^{, 50}$ Hospital guards were not the only sight women were drawn toward, many came simply to look upon maimed bodies. "Wednesdays and Fridays being visiting days, we had plenty of the fair sex coming to see the wounded and sick soldiers." Just as Bellard's curiosity at Manassas compelled him to the field hospital for the sole purpose of gazing at wounded soldiers, so too did citizens on the home front visit general hospitals in urban areas. These gawkers became such a nuisance that the surgeon in charge had to approve all visitations, "as lots of people came there out of mere curiosity to see the place and patients. ${ }^{, 51}$

\footnotetext{
${ }^{50}$ Bellard, 231.

${ }^{51}$ Bellard, 231.
} 
As opposed to the field hospitals the sanitariums in urban centers tended to be much more structured with specific wards designed for surgeries, convalescence, entertainment, cooking, laundry, barber shops, and in the case of Philadelphia's Satterlee Hospital, a printing office. Amanda Akin Sterns once likened the individual wards at Armory Square Hospital in Washington D.C. to a solar system revolving around the surgeon-in-charge. Hospital regulation extended to general security as well. Almost every northern military hospital appointed recovering inmates for guard duty. In an annual report to the Adjunct General of the State of Rhode Island, Colonel Crandall recognized that military police were essential at the hospital "to preserve internal order and prevent intrusions from without." His foresight paid dividends, at Portsmouth Grove General Hospital when "on several occasions, guards were ordered to escort visitors in and out of the hospital grounds, sometimes with a sergeant." Other hospitals found it prudent to implement regulations to help stem the tide of curious onlookers. As one newspaper warned, "No person will be allowed to visit the Hospitals without a pass except U.S. officers. ${ }^{, 52}$

Regardless of the policies they put in place hospitals often found themselves overwhelmed by tourists. At times it seemed as if the hospital acted more as a bourgeois gathering place for middle and upper class citizens than a space for recuperating men. "Dr. Bliss says fifteen hundred at supper time, it seemed as if I was having a reception." One woman "was singing at the piano" while the rest of the visitors "promenaded" around the ward. A particularly wealthy woman "a stout woman with plenty of diamonds" brought lemons for the soldiers, though Stearns admitted to finding "her not

\footnotetext{
52 Terry Reimer, One Vast Hospital: The Civil War Hospital Sites in Frederick, Maryland after Antietam (Frederick: National Museum of Civil War Medicine, 2002), 22.
} 
very interesting and a little pompous." Sterns confessed that the throng of people made it difficult to perform her duties. "Amid such confusion it was difficult to keep my wits." The impromptu soiree got so bad that "Dr Bliss denied all visitors from curiosity and we were much relieved." ${ }^{53}$ Above the din, however, the opportunity to showcase one's dedication to humanitarianism took center stage. William Rome did not expect much privacy as he recovered in an open ward in York, Pennsylvania. "The ladies are thicker than soldiers here. More than a Hundred here Every Day to bring provisions And Many other little Notions to the Sick.. ${ }^{54}$ The motivation to prove one's cultural superiority knew no bounds.

Competition over Christian humanitarianism extended beyond visitors and tourists. The looming threat of mortality, not to mention the intense suffering, made hospitals a prime location for religious sects to vie for the souls of wounded men. The overwhelming majority of religious volunteers sought only to alleviate the agony of disease and debility. "There are females calling themselves the Sisters of Charity here, all dressed in black and white collors [sic] \& sun bonnets \& wear a large gold cross. They help nurse the sick." 55 However, despite the philanthropic efforts by religious organizations protectiveness and resentment at times subsisted alongside caretaking. "Tension existed between the Protestant chaplain and the Catholic Sisters, since both sides felt they were in competition for the men's soul." ${ }^{156}$ Religious bias could be seen in the writing of soldiers and surgeons as well. Cyrus Bacon noted, "I do not doubt but

\footnotetext{
${ }_{53}^{53}$ Amanda Sterns, “Armory Square Hospital Nursing” Diary, May 21, 1864, National Library of Medicine.

${ }^{54}$ Clarke, 80.

${ }_{55}^{55}$ Heyward Emmell, 26.

${ }^{56}$ Reimer, One Vast Hospital, 22.
} 
some men die in Catholic hands because we have no Protestants as active [as they.] I hope our people will be more active in the hospitals."

\section{Informed Stares: The Desire for More}

By the close of the war the north had been embroiled in a long and bitter domestic struggle over the lengthening conflict. War weariness pushed many to advocate for peace negotiations and if it were not for Sherman's opportune capture of Atlanta, Abraham Lincoln might very well have lost his bid for reelection. Yet, concomitant to the discontent existed a desire for more information. Citizens and soldiers longed to understand the interrogative questions of the war; they wanted to experience its tragedies; to share in its triumphs; and feel its sufferings. Arguably, it was suffering that elicited the most attention. Major James Connolly of the $123^{\text {rd }}$ Illinois scolded his wife for her curiosity about war. "In your last letter you seem to think I don't give you enough description of battles armies, scenery, etc. If you were as tired of battles and armies as I am you wouldn't care to spend much time on them for they are very unpleasant things to be in and one does not like to reproduce memories of unpleasant things." her home, Mary Christian Percy pleaded with her brother to ease her "famous appetite for details." Percy's genuine, yet morbid, fascination with war prompted a litany of questions, “Can't you tell us how you live-\& how you employ your time-whether you go out picketing-or foraging-in fact what you do-\& how you do it." When her brother could not answer all her questions she stated, "I want to talk to one who has been in a bona-fide

\footnotetext{
${ }^{57}$ Cyrus Bacon, September 25, 1862.

${ }^{58}$ Earl Hess, "Tell me What the Sensations Are," 123.
} 
fight. I want him to tell me what the sensations are." ${ }^{, 59}$ Given the interest in all things war related, it is little surprise that many took it upon themselves to witness as much as possible, even if those scenes were repugnant. Whether their gazes were short-lived and infrequent or long and often, everybody stared. Soldiers, medical staff, volunteers, citizens, and even generals felt compelled to gape at bodily destruction. Regardless of their motivations, by touring battlefields and hospitals to stare at wounded soldiers, men and women connected to the war in ways much more poignant than fundraisers, letters, newspapers, photographs, or even the dizzying swirl of battle could allow.

\footnotetext{
${ }^{59}$ Mary Christian Percy to Henry, May 17, 1861, February 23, 1862, Augustus Cowan Papers, Illinois State Historical Library, Springfield.
} 


\section{Chapter 4 - "The public came to see the bones:" Bodies on Display in Mid Nineteenth-Century Museums}

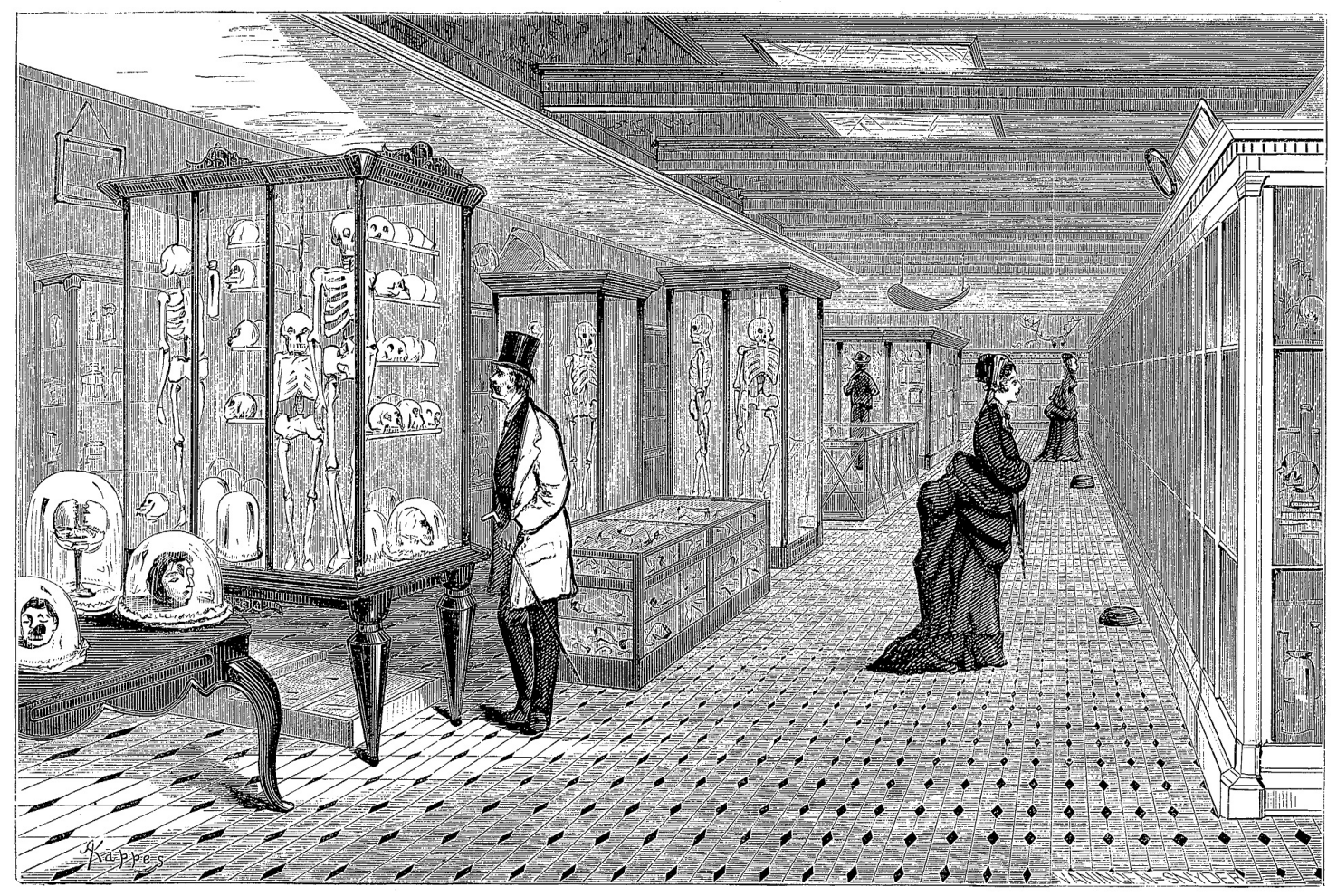

THE MATN HALL OF THE ARMY MEDTCAL MUSEUM.-WASHINGTON.

1

\footnotetext{
${ }^{1}$ Well-dressed men and women tour the Army Medical Museum and stare at the anatomical specimens on display. The AMM was considered one of "the sights" of postwar Washington D.C.
} 
Upon his promotion to Surgeon General of the United States Army in 1862, William A. Hammond launched a number of wide-reaching and important medical reforms. He increased the number of general hospitals, raised the admission requirements for acceptance into the Army Medical Corps, devised a promotion system based on competency instead of rank or connections, created a permanent military hospital, centralized the use of medicines by military physicians, and banned outdated medical practices, such as the use of mercury-laced calomel. ${ }^{2}$ Amidst these sweeping reforms he also managed to publish his Treatise on Hygiene, and laid the groundwork for the widely read Medical and Surgical History of the War of the Rebellion. His most farreaching policy, however, was the creation of the Army Medical Museum (AMM). ${ }^{3}$ In addition to housing extensive medical records throughout the war, the museum exhibited specimens of morbid anatomy for medical study and public gaze. ${ }^{4}$ When the war broke out, northern citizens who could not travel to the front lines or volunteer their time in hospitals, as well as benevolent organizations, used museums as a means to satisfy their curiosity about the war's damage while also taking part in a thriving entertainment industry.

The museum entertainment industry as a whole saw a dramatic rise during the antebellum period. Their mass appeal lay in unusual and abnormal exhibits, used to draw the public through their doors. Despite protest from moral reformers, museums

\footnotetext{
${ }^{2}$ The latter was directly responsible for his removal from office and subsequent court-martial. Known as the "Calomel Rebellion," conservative physicians felt that the banning of mercury infringed on their professional liberty. Secretary of State Edwin Stanton court-martialed Hammond based on falsified documents and he was dismissed on August 18, 1864. Hammond was later exonerated by act of Congress in 1874.

${ }^{3}$ Hereafter referred to as the AMM.

${ }^{4}$ The medical records were the foundation for the ground breaking medical series The Medical and Surgical History of the War of the Rebellion, a six volume series that greatly enhanced American medical prestige throughout the world.
} 
continued to expand by offering exotic, salacious, and macabre specimens. Though intended to be a space for medical and scientific enlightenment, the majority of attendants at most museums were non-professionals eager to gawk at the wondrous and anatomical pieces on display. Dime museums and the AMM were similar in a number of ways. Both displayed medical and scientific specimens designed to shock as well as enlighten. They each tapped into the relatively new field of advertising to increase their number of visitors, and both generated interest by building upon the public's morbid curiosity. Hammond's museum, however, differed from its cousins in a number of important ways. Unlike Barnumesque museums, the AMM was a legitimate source of medical and scientific material. The medical profession teemed with excitement over the amount of surgical and pathological specimens available for study after the war. In addition to affixing validity to the medical profession, the AMM also carried the authority and backing of the United States government. The federal government sanctioned exhibits making the display of soldiers not only legal, but also encouraged. The federal government actively invited men and women to stare at bodily remains even while surgeons, nurses, newspapers, and moralists disparaged the gawking behavior of citizens near battlefields and hospitals.

The federal sanction of Civil War bodies had a number of notable effects. First, it added authoritative weight to the medical field, increasing American medical esteem both nationally and internationally. The Medical and Surgical History of the War of the Rebellion, based its the information on the specimens collected by the AMM. Medical professionals worldwide wrote to the museum pleading for copies well into the twentieth century. Secondly, the display of soldier's bodies was carefully crafted, allowing the 
Union to narrate its own version of the war. By sponsoring the AMM, the government exhibited a measure of control over the representation, viewership, and public consumption of their displays. Contrary to the destructive chaos of war, the AMM was orderly, categorical, and did not threaten to overwhelm its visitors. Its glass jars and sterile environment created an air of introspection where visitors quietly walked throughout rows of specimens without the bedlam associated with battlefields and hospitals. The AMM, in effect, allowed citizens to see the transformative effect of war. Though the museum did not offer the same kinds of "living curiosities" found on battlefields, hospitals, and Barnumesque shows, its exhibits provided a forum for the observation and analysis of human abnormities. Lastly, the museum was an extension of the federal government's increased role in the public health field. After the war, the government became the leader in the research and promotion of public health concerns. The impact of the AMM and other war era anatomical museums could not have been possible, however, without the antebellum notions of disability and entertainment.

This chapter will argue that the exhibition of disabled soldiers and their bodies fit into a well developed system of anatomical display, which found its roots in the freak shows and dime museums of the antebellum period. Paramount to this display was the opportunity to see, and thus understand, the "normal" and "abnormal" body. Additionally, this chapter will build on the idea that the federally sanctioned display of soldiers' injuries during the war played a role in the shifting public discourse surrounding disability in the years following the war. The long dormant questions over the ethics of exhibition, ownership of anatomical remains, personal rights, and government assistance during the antebellum period found traction when applied to Civil War soldiers and their 
bodies. Scholarly work on the late nineteenth and early twentieth century reveal that disability, and its perception, proved to be an essential tool in the discriminatory arguments surrounding citizenship, immigration, and nativism. It is not the goal of this chapter to reiterate the scholarly work on disability in the postwar period, but rather to illustrate how the display of soldiers' bodies helped frame the discourse surrounding disability and deformity in the late nineteenth and early twentieth centuries. ${ }^{5}$

The exhibition of bodies did not come about suddenly during the war years. Such displays were a common part of most societies for centuries, and helped shape contemporary ideals of bodily image. To tell the story of exhibits is to narrate the historical construct of normality and deformity. A number of factors combined to mold the discourse of bodily image in the nineteenth century. The construct of deformity, and by extension, disability, follows an ideological path that thinks about the body under certain social and cultural parameters. As one scholar put it, "disability is not an object a woman with a cane - but a social process that intimately involves everyone who has a body and lives in the world of senses. ${ }^{\prime 6}$ Just as the perception of race, class, and gender impact the way in which we see the world around us, as does disability "dictate our ideas of normalcy." In fact, our perception of disability dictates the very concept of normalcy.

\footnotetext{
${ }^{5}$ For more on the constructive element of disability and its impact on social and cultural relationships see, Douglas Baynton, "Disability in History," Disabilities Studies Quarterly (Summer 2008) 28; Catherine J. Kudlick, "Disability History: Why We Need Another 'Other,'" American Historical Review 108 (June 2003), 763 - 93.; Douglas Baynton, "Disability and the Justification of Inequality in American History," The New Disability History: American Perspectives, ed. by Paul K. Longmore and Lauri Umansky (New York: New York University Press, 2001), 33-57; Susan Schweik, The Ugly Laws: Disability in Public, (New York: New York University Press, 2010).

${ }^{6}$ Lennard J. Davis, Enforcing Normalcy: Disability, Deafness, and the Body (New York: Verso, 1995), 2; Lennard J Davis, "Bodies of Difference: Politics, Disability, and Representation," in Disability Studies: Enabling the Humanities, ed. Sharon L. Snyder, Brenda Jo Brueggmann, and Rosemarie Garland-Thomson (New York: Modern Language Association of America, 2002), 100-101.
} 
The idea of normalcy, in our modern understanding, traces back to the midnineteenth century when Western culture began to focus on the grammatical use of the word "normal;" prior to this bodily image was popularly associated with the word "ideal." " According to Lennard J. Davis, the fluid nature of the word "ideal" allowed for a descending column of body image. The perception of an ideal body was highly individualized, drawing from a wide array of personal tastes, insecurities, and opinions. Everyone fell below their own standard, and so, existed in varying degrees of imperfection. In the eighteenth century Europe however, individualized standards underwent a process of codification, as statistics became the dominant method for measurement. In the wake of western culture's rapid growth, words like "norm" and "average" found common usage as a means of evaluation. Government policy, disease management, industrial sectors, class status, and even nascent credit scores all used statistics to quantify and visualize normality, and by extension, abnormality. In the postrevolutionary era, one did not need to have an ideal body to have a normal one. Much like the religious revivals of the of the early nineteenth-century, the egalitarian nature of "normal" appealed to republican-minded men and women who embraced a precept that could both legitimize the civic virtues and morals inherent in their uniformity as well as delegitimize those who were different. Such ideas played a powerful role in perpetuating the justification of racial superiority, male dominance, class structure, Darwinism, ambition, success, and nativism. ${ }^{8}$

\footnotetext{
${ }^{7}$ The word "normal" entered the English language around 1840 while "normalcy" made its first appearance in 1857. The linguistic impact is all the more apparent in that it occurred on the cusp of the Civil War, when million's of bodies were threatened by disability or abnormality. Lennard J. Davis, "Constructing Normalcy: The Bell Curve, the Novel, and the Invention of the Disabled Body in the Nineteenth Century." ${ }^{8}$ Drastic changes in market relations, transportation, communication, industrialization, urbanization, class development, and leisure had a fundamental impact on shifting American values and ideas.
} 
The concept of normality merged with body image at the very moment that the United States underwent a number of significant changes. Not only did American culture begin a homogenizing effect from drastic changes in the marketplace, religion, transportation, and communication, but the swift modernization of the north also reconfigured the way men and women perceived the body. Wage labor forced bodies to adhere to rigid schedules; machines began to replace manpower, and standardization and interchangeable parts demonstrated the value and efficacy of uniformity. Abolition and women's movements challenged white male authority on the basis of the autonomy of their bodies. Moreover, industrial accidents and the Civil War, quite literally, had a transformative effect on the body, harshly severing victims from their sense of normalcy. Given all of these factors, it is no surprise that Americans sought ways to reinforce their own normality. Civil War era museums were one way that men and women could reaffirm the value of their own bodies. By using disabled bodies as exhibition pieces, museums assuaged anxieties wrought by the war while promoting a national identity, without the austere brooding of moralists. ${ }^{9}$

Sensation, Deformity, and Murder: The Public's Fascination Grows

By the time of the Civil War, the northern public already had a long tradition of utilizing disabled and deformed bodies in various entertainment forms. Freak shows, art galleries, traveling fairs, circus's, and museums capitalized on the public's growing fascination with the abnormal. Karen Halttunen captured this sentiment in her essay on the impact of humanitarian sensibilities and the rise of gothic and sadistic literature,

\footnotetext{
${ }^{9}$ Rosemarie Garland-Thomson, ed., Freakery: Cultural Spectacle of the Extraordinary Body (New York: New York University Press, 1996), 11. It is interesting to note that the popularity of freak shows and anatomical museums occurred from 1840-1940, roughly the same time line as American industrial growth.
} 
which proliferated in urban areas during the late eighteenth and early nineteenth centuries. She argued that philosophical thinkers of the period sought to make sense of how an increasingly ethical and sympathetic ideology could be so fascinated by the destruction, torment, and deformity of human bodies. To understand this phenomenon, thinkers investigated the cognitive transition between ethics and spectatorship. Philosophers like John Locke, Francis Hutcheson, David Hume, and Adam Smith began testing their theories of ethics by connecting them to various forms of visual stimuli. The formula they came up with treated ethics "as a matter of sentiment, sentiment as a matter of sympathy, and sympathy as a matter of spectatorship."10 The relationship between sympathy and spectatorship explains why citizens and soldiers flocked toward scenes of death and mutilation in hospitals and battlefields to witness the destruction first hand. In order for sympathy to take place, one first had to "see" the object of suffering, either in person or in one's mind's eye. "By the imagination we place ourselves in [the sufferer's] situation, we conceive ourselves enduring all the same torments, we enter as it were into his body, and become in some measure the same person with him, and hence form some idea of his sensations, and even feel something which, though weaker in degree, is not altogether unlike him." ${ }^{\prime 1}$ Smith's statement explains why some people gravitated toward the wounded. Famed transcendentalist, Walt Whitman, utilized this same concept in a number of his letters and poems. After hearing that his brother endured injury during the battle of Fredericksburg, Whitman immediately boarded a train for D.C. then travelled to the war front in search of his sibling. Throughout his search, he came in contact with numerous injured men and became inspired to sign up as a volunteer nurse. His

\footnotetext{
${ }^{10}$ Karen Halttunen, "Humanitarianism and the Pornography of Pain in Anglo-American Culture," American Historical Review (April 1995): 307.

${ }^{11}$ Adam Smith, The Theory of Moral Sentiments, quoted in Halttunen, 307.
} 
experience with wounded soldiers laid the groundwork for some of his most famous works of poetry. The suffering of others, and the proximity to their pain, inspired and fueled Whitman's poetry. In a correspondence with a friend, Whitman attested to his need to be close to the suffering of others.

These Hospitals, so different from all others - these thousands, and tens of twenties of thousands of American young men, badly wounded, all sorts of wounds, operated on, pallid with diarrhea, languishing, dying with fever, pneumonia, etc., open a new world somehow to me, giving closer insights, new things, exploring deeper mines than any yet, showing our humanity, (I sometimes put myself in fancy in the cot, with typhoid, or under the knife,) tried by terrible, fearfulest tests, probed deepest, the living soul's, the body's tragedies, bursting the petty bonds of art. To these, what are your dramas and poems, even the oldest and tearfulest? ${ }^{12}$

Just as Smith had theorized, Whitman's fascination with the wounded stemmed from his sympathy for wounded soldiers, while also attesting to his role as a spectator to the suffering around him. Within the framework laid out by philosophers, Whitman needed to imagine himself under the knife in order to more fully understand the war.

The relationship between sympathy and spectatorship was not unique to the Civil War. In the Incorporation of America, Allan Trachtenberg described how everyday life experience transformed in the late nineteenth century. The advent of mechanized reproduction led to an emergence of increased visual experience in the way of advertisements, department store displays, newspapers, and magazines. The profusion of visual stimuli blurred the lines of respectable deference and abject speculation. Mass circulation sought to increase readership by publicizing graphic columns of sex and murder under the guise of human-interest stories. The sensationalism of newsprint was readily apparent throughout the 1836 trial of Richard Robinson. Robinson, the nineteenyear-old son of a long-time state congressman, was accused of the bloody axe murder of

\footnotetext{
${ }^{12}$ Walt, Whitman Correspondence.
} 
Helen Jewett, a popular prostitute in New York City. Hewett's killer had struck her in the head with an axe, then set fire to the bed in the hopes of destroying any evidence. The murder of Helen Jewett provided everything newspapers craved: sex, gruesome murder, well-connected public figures, as well as a blend of debauchery and respectability. An insatiable public ensured that newspapers would continue printing lurid details, going so far as to investigate every aspect of Jewett's childhood, friends, personal life, wardrobe, books she read, the poetry she wrote, and her list of clients. Newspapers were also in the habit of inventing any information they could not find. Newspapers from Mississippi to Maine published daily accounts of the trial and carried lengthy reports filled with gory descriptions, creative crime scene scenarios, and shocking illustrations of the murder. The New York Herald boosted its circulation from five to fifteen thousand copies a day. ${ }^{13}$ The public's fascination with Helen Jewett's murder prompted the news media press to begin an entire series of articles that focused entirely on the gruesome aspects of a crime stories.

The demand for descriptive crime stories prompted newspapers to seek out new sources for their reading audience. In one such instance newspapers published the closing arguments of Daniel Webster in his prosecution of George Crowninshield, accused of clubbing and stabbing an army captain. Known for his flights of literary Romanticism, Webster merged the scandalous elements of murderous appeal with romantic agony of mythical proportions. Daniel Webster argued that "pleasure could be gathered from the elements of pain, and beauty seen in the Gorgon's head of horror." Newspapers and trial transcripts were successful because the lurid details enhanced the

\footnotetext{
${ }^{13}$ Patricia Cohen, The Murder of Helen Jewett: The life and Death of a Prostitute in Nineteenth-Century New York (New York: Random House Publishing, 1998); Leroy Ashby, With Amusement For All: A History of American Popular Culture Since 1830 (Lexington: University Press of Kentucky, 2006).
} 
mental pictures constructed in the imaginations of the fascinated American public. Trial reports, criminal biographies, and media outlets became increasingly descriptive in their accounts by inviting readers to envision violent scenes and watch them unfold in their imaginations. They directed attention to bloody scenes of carnage, the wounds inflicted, and the suffering of the victim in a language calculated to evoke horror even as it testified to their presumed fascination with such shocking bloodshed. ${ }^{14}$ Their mind's eye proved an intoxicating elixir that only fueled their interest in the abnormal, gruesome, and deformed rather than slaked their thirst for such material. ${ }^{15}$

Fascination with scenes of injury, deformity, and death grew alongside an urbanizing nation. Technological advancements in transportation and industry offered a Petri dish of danger, mayhem, and wonder for the public's growing sense of curiosity over malformation and death. Accounts of steamboat explosions, train wrecks, and industrial accidents dominated American publishing. Even famed diarist Philip Hone could not resist the urge to write about the "garroting stories" of New York's newspapers. "I never take up a paper that does not contain accounts of loss of life, dreadful mutilation of limbs, and destruction of property, with which these reckless, dangerous, murderous modes of locomotion are attended," he wrote in $1847 .{ }^{16}$

Entertaining Disability and Deformity: The Antebellum North

\footnotetext{
${ }^{14}$ Civil War letters, diaries, and newspaper were often quite graphic in their description of wounded and dying soldiers. Such authors typically denounced these horrific sights even while standing transfixed at the scene.

${ }^{15}$ Trial of George Crowningshield, J.J Knapp, and John Francis Knapp for the Murder of Capt. Joseph White, (Boston, 1830), quoted in Haltunnen, 311-12. Frances Clarke. War Stories: Suffering and Sacrifice in the Civil War North (Chicago: University of Chicago Press, 2011).

${ }^{16}$ Hone, Order Hierarchy, and Culture, quoted in Haltunnen, 312.
} 
Gritty newspaper stories grew in tandem with other modes of entertainment that emphasized the gruesome and abnormal. Crafty entrepreneurs sought ways to take advantage of this new social trend by popularizing, and legitimizing, forms of entertainment previously viewed as inappropriate for respectable audiences. Prior to the nineteenth century most of these amusements were singular attractions, human oddities that could be seen for a fee in travelling fairs, tavern rooms, and public squares. The market revolution ushered in a new form of exhibitionism and spectatorship. Small troupes or one-person displays evolved into commercial enterprises complete with managers, showmen, promotional advertisements, business contracts, "talent" scouts (whose responsibility it was to locate and sign potential attractions), and even promotional men who arrived ahead of traveling shows and circuses to drum up local interest. ${ }^{17}$

In an effort to appease moralists and social detractors, exhibitors sought to legitimize their "curiosities" by blurring the lines of science, medicine, and race. ${ }^{18}$ In 1796, Henry Moss, a black man from Virginia whose body seemed to be whitening over time, exhibited himself in local taverns and museums across Philadelphia. Moss spoke in front of eager crowds, and charged twenty-five cents per person, a hefty fee in the post revolution period. His condition caused such a stir that the American Philosophical Society invited him to showcase his affliction at Leech's Tavern, a popular meeting place for the city's most esteemed residents. The caliber of men present at Moss's event speaks to the level of interest in human abnormality; men such as George Washington, Reverend

\footnotetext{
${ }^{17}$ Ashby.

${ }^{18}$ Robert Bogdan. Freak Shows: Presenting Human Oddities for Amusement and Profit, (Chicago: University of Chicago Press, 1988).
} 
Samuel Stanhope Smith, Charles Cadwell, and Benjamin Rush were all in attendance. ${ }^{19}$ Public interest only increased as local and national leaders validated the exhibition and amusement of extraordinary bodies. So much so, that Moss's likeness went on to grace the pages of German almanacs and European chocolates, further adding to his international appeal.

By the 1840s, the exhibition of "freaks" was quickly on its way to becoming one of the most dominant forms of cultural entertainment in America. The emergence of freakery coincided with the first large-scale influx of immigration into the United States. Nearly three million Irish and German immigrants arrived in coastal cities in the decades prior to the war, the bulk of which stayed in New York City. Anxieties over "American" identity and culture prompted intense hostility toward these foreign-born newcomers. In a kind of religious cleansing, anti-Catholic riots broke out all across the city. Nativists formed political parties like the Know Nothings, whose platform focused on limiting the rights of immigrants. Similar to freed blacks in the city, these ethnic groups were relegated to the bottom rung of the economic ladder and became the scapegoat for many social problems of the period. In an effort to ameliorate anxieties over the changing urban landscape, it became popular to depict Irish and German immigrants as drunken ape-like beasts. These illustrations highlighted the deformed nature of their bodies while reinforcing racial stereotypes. The comparison of immigrants and blacks seemed quite

\footnotetext{
${ }^{19}$ Reverend Samuel Stanhope Smith was a leading racial theorist while Charles Cadwell and Benjamin Rush prominent physicians in the city, the latter of which is considered the father of American psychiatry. Henry Moss suffered from vitiligo, a condition that causes depigmentation of parts of the skin. Vitiligo affects less than $1 \%$ of the world population and would have been regarded as an exotic oddity, thus ensuring his profitable exhibition to medical practioners and the public. Bogdan, 27. Harriet A. Washington, Medical Apartheid: The Dark History of Medical Experimentation on Black Americans from Colonial Times to the Present (Knopf Doubleday Publishing, 2007).
} 
natural to native-born citizens based on the racial inferiority both groups held. ${ }^{20}$
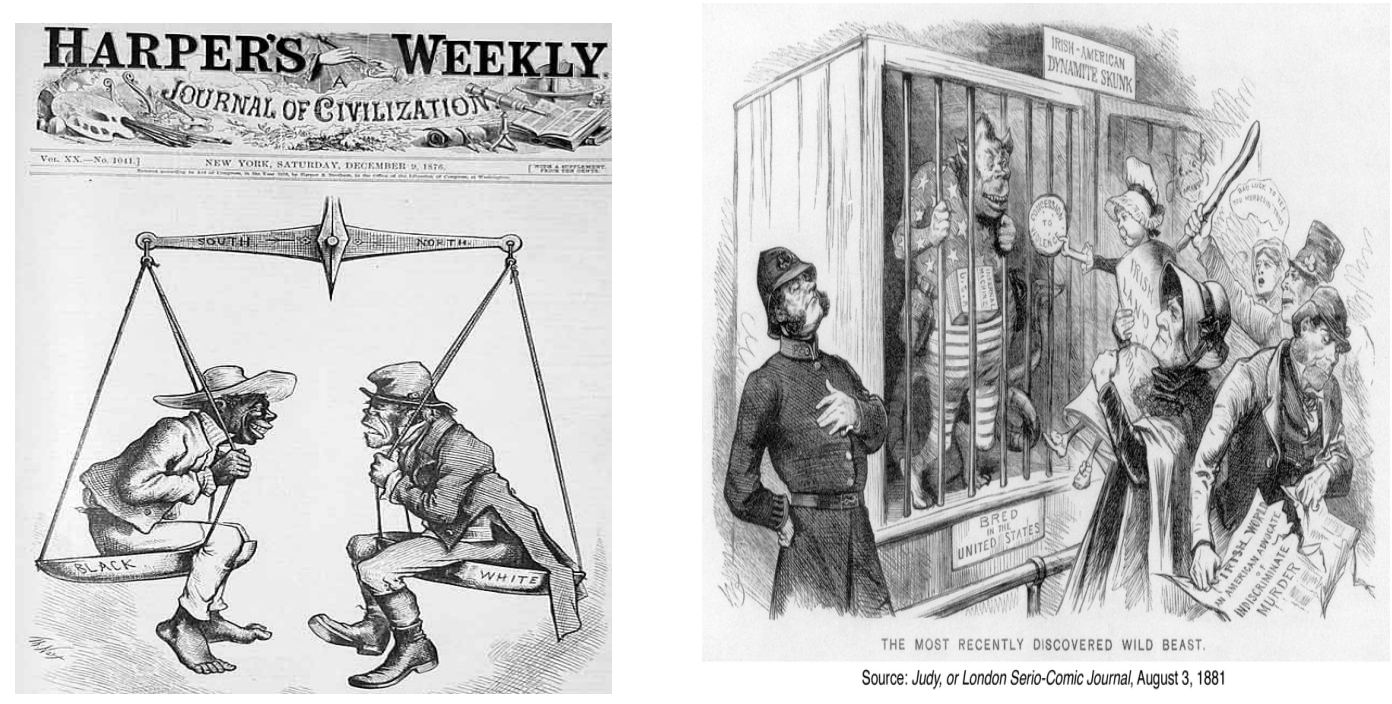

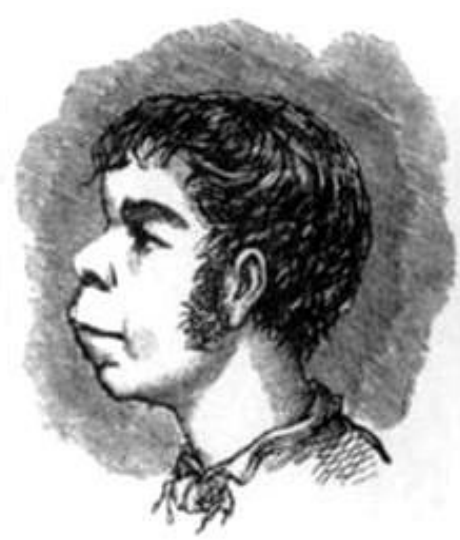

IRISH IBERIAN

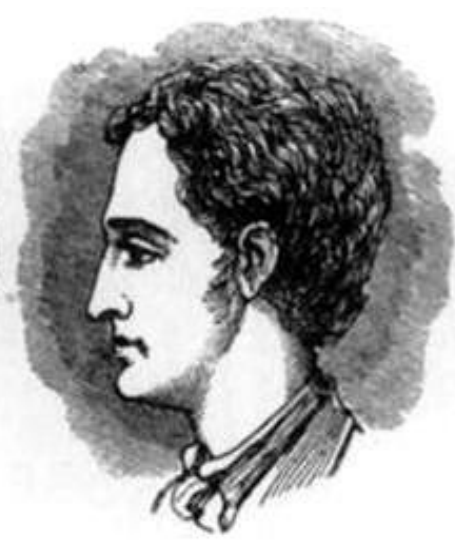

ANGLO-TEUTONIC

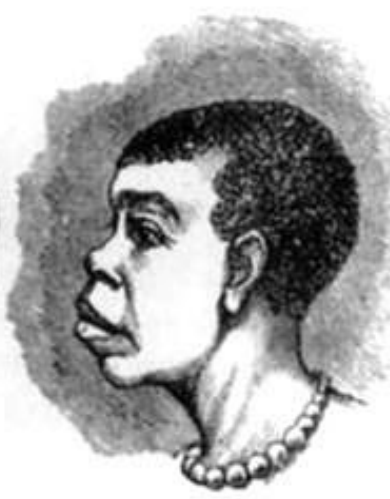

NEGRO

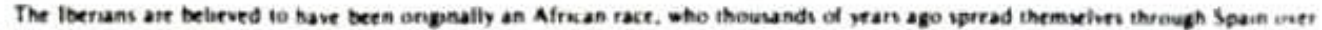

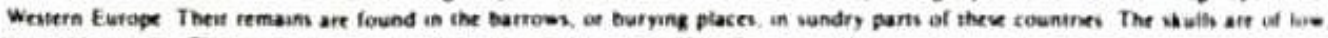
prograthous type. They came to iecland, and mised with the natives of the South and West, who ihemuelves are supposed so have bers ud

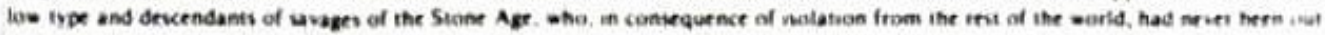

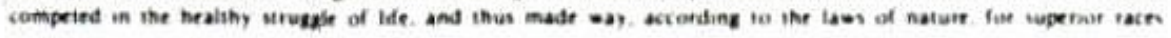

${ }^{20}$ James Cook, Race and Relations in P.T. Barnum's New York City, http://chnm.gmu.edu/lostmuseum/lm/117/. 
While the blend of race and bodily abnormality had taken place for centuries, it was not until the second half of the nineteenth-century that the organized exhibitions of people with physical and mental anomalies were readily accepted into mass American culture. This profit driven industry went by many names, but whether they were called Dime Museums, Anatomical Museums, Side Shows, Freak Shows, Odditoriums, Halls of Curiosity, or Circuses these places all shared one common denominator: they provided amusements based on abnormality.

One of the earliest museums open to the public occurred in the midst of the democratizing spirit of the American Revolution. In 1784, Charles Willson Peale started the first popular museum aimed at satisfying the curiosity of the general populace. Traditional museums of science were largely the province of the "cognoscenti" or the "wealthy amateur's pleasure," but Peale envisioned a more egalitarian approach to museum going. ${ }^{1}$ Rational amusement - the idea that amusement need not be frivolous if it incorporated learning - gained traction throughout the eighteenth century and into the early nineteenth-century. Peale's dream was to create a space that promoted education and spectatorship for working-class laborers and wealthy gentlemen alike. Unfortunately, his tremendous success was ultimately the museum's undoing. Peale underestimated the public's growing appetite for oddities. Peale piqued their curiosity with racial and exotic wonders; mastodon legs and Native American skulls drew throngs of people to the museum, each in search of the next big sensation. As Alexis de

\footnotetext{
${ }^{1}$ Amateur collectors of human and animal specimens proliferated throughout the era reaching its height in the late nineteenth century. The "curiosity cabinets" of wealthy collectors contained everything from ethnic and racial skulls to the mummified remains of infants. Frequently put on display for house visitors, these cabinets articulated one's refinement and scientific intelligence to his guests. For more on skull collection and curiosities see Ann Fabian, The Skull Collectors: Race, Science, and America's Unburied Dead (University of Chicago Press: Chicago, 2010), Charles Coleman Sellers, Mr. Peale's Museum: Charles Willson Peale and the First Popular Museum of Natural Science and Art (New York: W.W. Norton and Company, 1980), 1.
} 
Tocqueville noted "[Americans] clutch everything but hold nothing fast, and so lose grip as they hurry after some new delight." ${ }^{2}$ Eager to take advantage of the public's capricious nature, imitators of Peale's museum sprung up in almost every major city across the northern United States. Tawdry and specious museums took advantage of the public's appetite for new delights. Even anatomical museums dedicated to science and medicine could not resist temptation of exhibiting abnormal displays. One such educational museum featured a "withered arm" fused within the trunk of a tree in order to boost attendance. The success of educational museums like Peale's paved the way for an entirely new cultural approach to the rational amusement of museums. ${ }^{3}$

At the forefront of this cultural phenomenon lay one of the most notorious and cunning entrepreneurial minds of the mid nineteenth century. Phineas Taylor Barnum and his American Museum marked a turning point in commercial entertainment by inculcating a culture of human spectacle and exhibitionism that relied upon the active participation of the paying public. Barnum set himself apart from his peers by successfully using the public's attraction to "curiosities." Barnum's success centered on his ability to make the spectacle of freaks and disabled bodies socially acceptable for women and children of various social classes. Promotional exhibits such as Joyce Heth; What is It?; the Feejee Mermaid; the diminutive Tom Thumb as well as conjoined twins Chang and Eng; blended "pseudoscientific jargon" with "fantastic hyperbole" to present

\footnotetext{
${ }^{2}$ Alexis De Toqueville, 1831.

${ }^{3}$ Mary Clemmer Ames, Ten Years in Washington: Life and Scenes in the Nation's Capital, as a Woman Sees Them (Hartford: A.D. Worthington \& Co., 1874), 478.

${ }^{4}$ Allen Trachtenberg, The Incorporation of America: Culture and Society in the Gilded Age (New York:

Hill and Wang, 1982).
} 
audiences with what Michael Sappol described as, "a carnival of self and other." addition to refining the image of normal versus abnormal bodies, Barnum's museum "helped to articulate many of the dominant racial attitudes of this era."

Born the son of an innkeeper in 1810, Barnum grew up in the small town of Bethel, Connecticut. His natural flair for entrepreneurship took root at an early age through several businesses ventures. By his twenty-fifth birthday he had already began and sold a general store, real estate business, book auctioneering, and a state-wide lottery scheme, in addition to a weekly paper in 1829, The Herald of Freedom, which led to a two month incarceration due to inflammatory articles about the local church elders. However, It was not until 1835 that Barnum took his first steps into the burgeoning world of commercial entertainment. Barnum's career as a showman began with his purchase and exhibition of Joice Heth, a woman he advertised to be a 160 -year-old blind slave, supposedly the nursemaid to George Washington. While working in his New York grocery, an old acquaintance from Connecticut approached Barnum and showed him a recent advertisement in the Philadelphia Inquirer.

CURIOSITY - The citizens of Philadelphia and its vicinity have an opportunity to witness at the Masonic Hall, one of the greatest natural curiosities ever witnessed, viz., JOICE HETH, a negress 161 years, who formerly belonged to the father of George Washington. She has been a member of the Baptist Church one hundred and sixteen years, and can rehearse many hymns, and sing them according to former custom. She was born near the old Potomac River in Virginia, and has for ninety or one hundred years lived in Paris, Kentucky, with the Bowling Family.

\footnotetext{
${ }^{5}$ Rachel Adams, "Caught Looking." A Cabinet of Curiosities 4 (Jan 2004) http://www.commonplace.org/vol-04/no-02/adams/; Michael Sappol, "Morbid Curiosity: The Decline and Fall of the Popular Anatomical Museum.” A Cabinet of Curiosities 4, (Jan 2004) http://www.common-place.org/vol-04/no02/sappol/.

${ }^{66}$ James Cook, "Race and Relations in P.T. Barnum's New York City," http://chnm.gmu.edu/lostmuseum/lm/117/.
} 
Barnum, who had spent much of the year looking for an avenue into the business of spectatorship and exhibition, immediately abandoned his partnership in the Manhattan grocery, took out a loan, boarded a train to Philadelphia and purchased the traveling exhibition show. By August of 1835, Barnum signed a contract to exhibit Heth for ten months in the cosmopolitan center of New York City at the intersection of Broadway and Prince, otherwise known as the Bowery district. The location was a significant one as this area of the city was on the cusp of becoming the leading urban entertainment district in the United States. Filled with mechanized panorama paintings, enticing burlesque shows, trompe l' oeil entertainment magicians such as Signor Antonio Blitz, as well as the famous Scutter's American Museum and the "pleasure gardens" of Niblo's, the Bowery provided the perfect place to begin his foray into the amusement industry. ${ }^{7}$ In the words of historian James Cook, the location connected Barnum's exhibit to "the massive expansion of commercial entertainment that began to take shape on and around lower Broadway." Marking this moment as "the birthplace of American popular culture."

Barnum drew upon the public's natural curiosity of abnormal bodies to entice the paying public to view his "living mummy." Playing up her debilitations and patriotic connections he touted her as the "Greatest Natural and National Curiosity in the World." She "might almost as well have been called a thousand years old as any other age," Barnum stated. "She was totally blind, and her eyes were so deeply sunken in their

\footnotetext{
${ }^{7}$ trompe l' oeil is an art technique that uses realistic imagery to create three dimensional optical illusions. Barum eventually purchased Scutter's Museum and renamed it The American Museum.

${ }^{8}$ James Cook, The Arts of Deception: Playing With Fraud in the Age of Barnum (Cambridge: Harvard University Press, 2001), 3.
} 
sockets that the eyeballs seemed to have disappeared altogether. She had no teeth, but possessed a head of thick bushy gray hair."

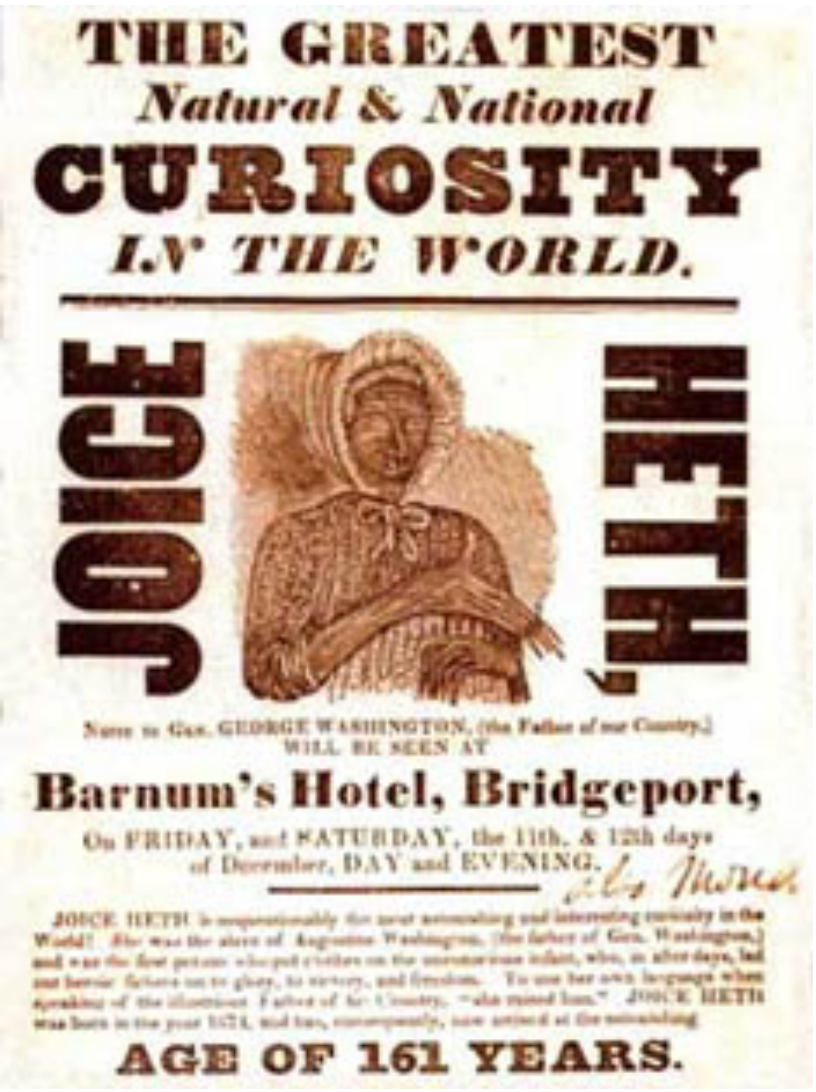

With one eye toward critics, Barnum devised an entire marketing campaign to alleviate concerns over the legitimacy of Heth's age. By circulating baptismal records (forged of course) and publishing a short biography of Joice Heth, Barnum could couch the mystery of his 161-year-old exhibit within the murky water of patriotic nursemaid to George Washington or a wizened slave fraud. In the words of Benjamin Reiss, "audiences could view her as a pious, moral, patriotic woman or as an aged black freak a spiritual vessel or a human grotesque."10 Heth played the role of a living curiosity superbly inviting audience members to ask her questions, singing hymns, telling jokes,

\footnotetext{
${ }^{9}$ P.T. Barnum, The Life of P.T. Barnum, Written by Himself, 1855 reprint, (Urbana: University of Illinois Press, 2000), 148-49.

${ }^{10}$ Benjamin Reiss, The Showman and the Slave: Race, Death, and Memory in Barnum 's America (Cambridge: Harvard University Press, 2010), 88-89.
} 
and flirting with patrons. She even offered to marry one young man if she "could find no one else," adding that there were a "great many others too old for [her]." It was this kind of active participation with the audience that Barnum relied upon to keep customers interested in his exhibits, a marketing ploy he continued to exploit as his business grew. He even went so far as to allow customers to shake her hand and take her pulse, the equivalent of today's Please Touch museums aimed at creating a more interactive experience for museum-goers.

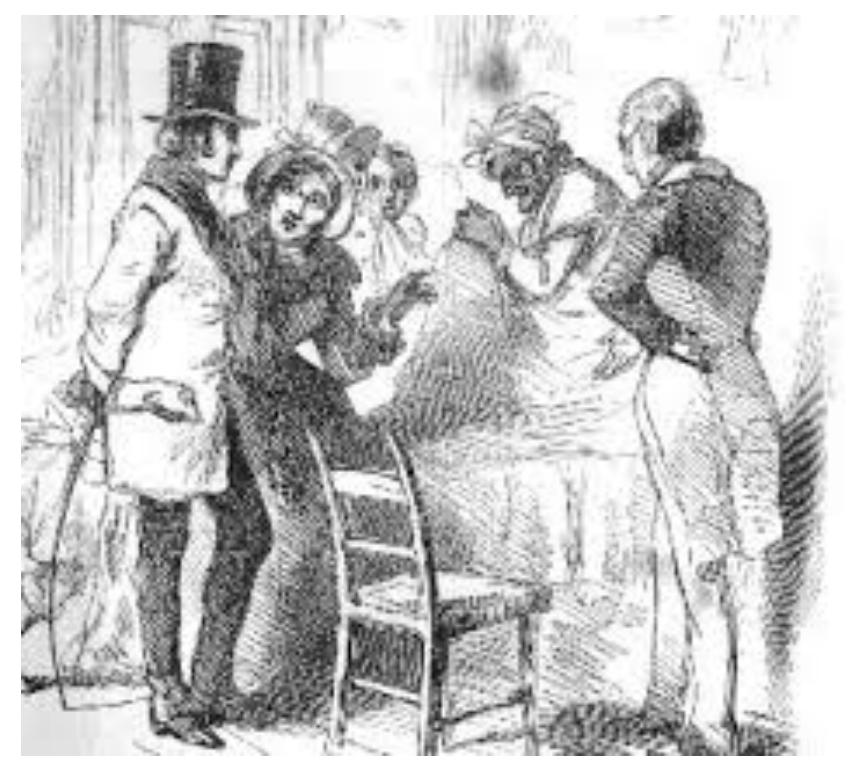

Barnum found great success with his Heth exhibit, making as much as $\$ 1,500$ a week during his tour. The endless travel and grueling fourteen-hour work days, however, proved to be too much for the aged woman who died on February 18 1836, eight months after Barnum first exhibited her. After Heth's death, Barnum re-marketed his curiosity to hone in on the mystery surrounding her true age. Despite widespread revulsion toward dissection during the antebellum period, the general public welcomed the autopsy of Heth's body. Nearly 1,500 men flocked to Manhattan's City Saloon on Broadway to 
watch the public dissection of Heth's body. ${ }^{11}$ The autopsy turned out to be a financial boon for Barnum who pocketed over $\$ 700.00$ during the event.

With the profits from Heth's exhibition and dissection, Barnum created one of the most popular places for amusement and entertainment in the northeast. His displays focused primarily on exploiting the public's curiosity toward the exotic and abnormal. In 1841, he purchased the struggling Scudder's American Museum, a few blocks from New York's Bowery district on Broadway and Ann Street, and renamed the building after himself. Strategically located in an area that bridged the city's upscale shopping establishments and the crowded Bowery tenements, Barnum's American Museum drew from an eclectic assortment of individuals. Tourists, middle class shoppers, various ethnic and racial groups, and working-class B'hoys and G'hals made up the crowds. This nexus of activity provided immediate profits to the American Museum. Patrons could browse among as many as thirty thousand exhibits including waxworks, an assortment of weapons and armor, an aquarium, and a menagerie of live animals. ${ }^{12}$

It was the upper floors however, that drew the largest crowds to Barnum's American Museum. These floors housed the most popular, yet controversial, exhibits: human curiosities and freaks. For twenty-five cents audiences could gawk at any number of exotic and abnormal bodies. The heavily tattooed Greek Prince, Constentenus; Madame Clofullia, the bearded lady from Switzerland; A Russian "dog-faced boy” whose entire body was covered in hair, a Canadian legless wonder, as well as a variety of

\footnotetext{
${ }^{11}$ Michael Sappol, A Traffic of Dead Bodies: Anatomy and Embodied Social Identity in the NineteenthCentury America (Princeton: Princeton University Press, 2002); Ashby, 31. Dr. Rodgers determined that Joice Heth could not have been more than eighty years of age, to which Barnum claimed that he too was the victim of a hoax.

${ }^{12}$ Barnum's menagerie consisted of tigers, giraffes, crocodiles, sloths, a hippopotamus and in 1857 the museum even featured a whale.
} 
albinos, giants, and midgets, each with a foreign background. Racial exhibits included were Aztec conjoined twins from Mexico, African "wild men," and various "mongrels.",13 Most of these exhibits advertised exotic backgrounds and augmented existing stereotypes. While these "living curiosities" did not focus on a central ethnicity or race, taken together, they all served to "create a spectrum of freakishness" ancillary to the white middle-class perception of normalcy. The display of disabled freaks evoked a number of reactions from patrons. Audiences were simultaneously titillated and reassured by abnormal bodies, which presented human oddity as a medium for inquisitiveness, apprehension, animosity, sympathy, and superiority. In a rapidly industrializing and urbanizing society, spectators took solace in the opportunity to define themselves against those strange "others" whose presence helped distinguish the normal from the abnormal. These exhibits, therefore, did more than exhibit the transformative effects of the body, rather these displays revealed the stark anxieties of a society coming to grips with foundational changes in demography, race, and power. ${ }^{14}$

Barnum's success was largely due to his ability to make the exhibition of freakery a form of middle-class entertainment, safe for women and children. During the first half of the nineteenth century urban reformers in the north increasingly sought to police the nation's morals by attacking drunkenness, rowdiness, and a general censorship of behavior. As one magazine put it in 1851: "Let our readers remember that we were sent into the world, not for sport and amusement, but for labor; not to enjoy and please ourselves, but to serve and glorify God."15 Under the onslaught of such attacks, circuses,

\footnotetext{
${ }^{13}$ Mongrel was the term given to the mentally disabled.

${ }^{14}$ Ashby, 33.

${ }^{15}$ Elliot J. Gorn and Warren Goldstein, A Brief History of American Sports (University of Illinois Press, 2004), 60 .
} 
museums, fairs, and other forms of popular entertainment, would have to reckon with such moralists.

P.T. Barnum responded to reformists with his typical creative flair. Barnum knew his "living curiosities" would prove to be a financial boon to him if only he could make his exhibits palatable to the moral sentiments of the city's respectable citizens. In 1847 , he joined the temperance movement and signed the "teetotaler pledge" after a dangerous brush with alcoholism. He also banned intoxicating liquors from his museum refusing even his visitors from imbibing prior to entering his place. Moreover, he hired "half a score of detectives dressed in plain clothes, who...turned into the street every person of either sex whose actions indicated loose habits." Barnum even sought to bring a sense of respectability to the old "puritanical horror" of theatre by hosting anti-liquor plays in his lecture room. His performance of The Drunkard and other morality plays brought in as many as three thousand people during a run and "ministered to a refined and elevated popular taste." Citizens attending these plays could sign their own teetotaler's pledge, provided by Barnum himself. By 1865 Barnum proudly boasted that "no vulgar word or gesture and not a profane expression was ever allowed on my stage."16

While Barnum and other centers of popular entertainment would always have their detractors, they were largely successful in reshaping their amusements into reputable middle-class institutions. By the time of the Civil War, dime museums, anatomical museums, and other popular amusements clamored to create family friendly spaces. The Peale Museum, still focused on idea of "rational amusement" began exhibiting "living curiosities" such as the Belgian Giant, Hungarian Minstrels, and the

\footnotetext{
${ }^{16}$ Ashby; A. H. Saxon. P.T. Barnum: The Legend and the Man (New York: Columbia University Press, 1989) 107; Bruce A. McConachie, Melodramatic Formations: American Theater and Society, 1820-1870 (Iowa City: University of Iowa Press, 1992), 161.
} 
Automaton Chess Player, all oddities, which were deemed safe for women and children.

The Pacific Museum in San Francisco was careful to cater their exhibits toward respectable audiences only. One advertisement read, "The Pacific Museum of Anatomy and Science is intended to promote the knowledge and morality of the general public - to act as a beacon to the young." Barnum himself frequently advertised his museum as a "perfectly safe place for ladies and children...unaccompanied by gentleman." Even circuses, long condemned by various Christian denominations and reformers as "insidious and pernicious amusement," began to tailor their shows toward respectable audiences. Emily Dickinson herself defended the reputation of circus-goers, "there would be nothing in the performances to offend the most cultivated, moral, or refined"17

\footnotetext{
${ }^{17}$ Sellers, 288; Handbook \& Descriptive Catalogue of The Pacific Museum of Anatomy and Natural Science: Now open in the Eureka Theatre Louis J. Jordan, found at the National Library of Medicine digitized collection http://archive.org/details/0221773.nlm.nih.gov; The Sights and Wonders in New York: Including a description of the mysteries, miracles, marvels, phenomena, curiosities, and nondescripts, contained in that great congress of wonders, Barnum's Museum (New York: J.S. Redfield, 1849), The Library Company of Philadelphia; Robert M. Lewis, ed., From Traveling Show to Vaudeville: Theatrical Spectacle in America, 1830-1910 (Baltimore: John's Hopkins University Press, 2003), 110; Emily Dickenson Letters to Dr. and Mrs. Josiah Gilbert Holland. May 1866 (Cambridge: Harvard University Press, 1951), 74.
} 

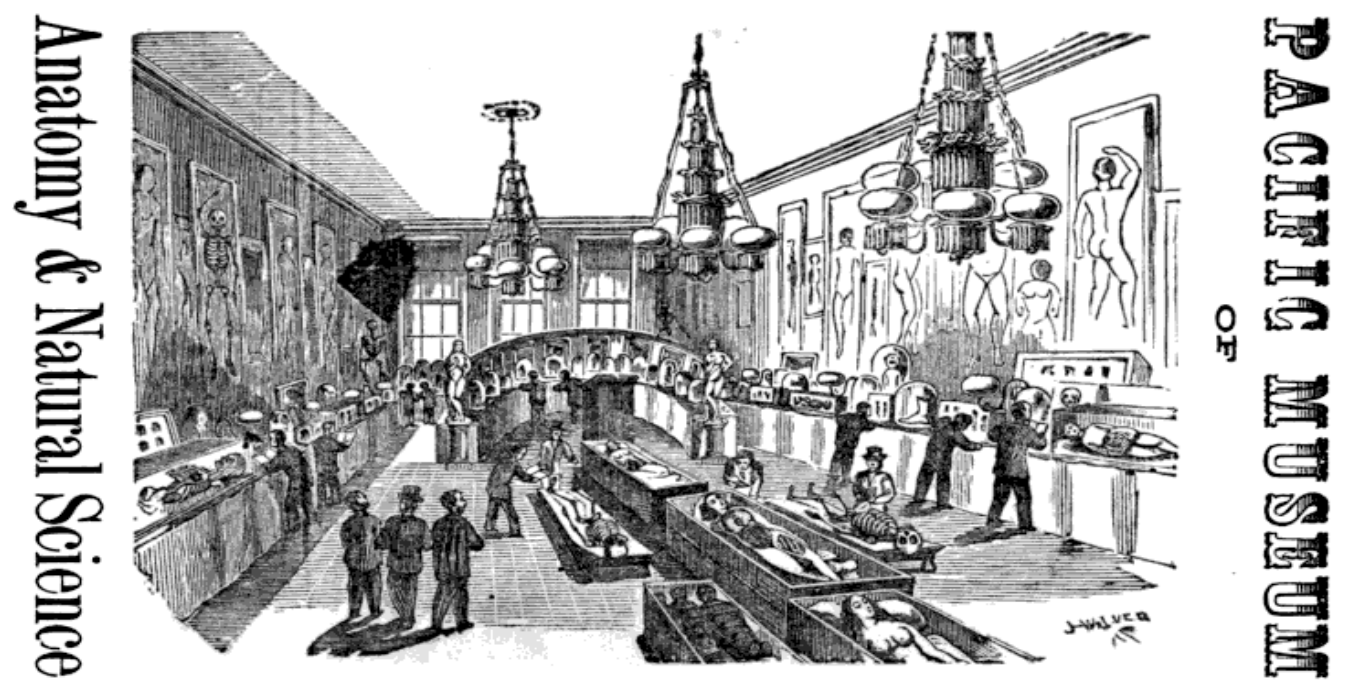

A Currier \& Ives lithograph provided proof of the family friendly environment in Barnum's Museum. In what was perhaps his most attractive and interactive human curiosity, Barnum piqued the interest of his patrons by combining the "characteristics of both the HUMAN and BRUTE species." ${ }^{18}$ Relying on exhibitionism and racial prejudice, WHAT IS IT? or MAN MONKEY featured a diminutive stooped black figure standing in the center of well dressed men, women, and children. As the picture shows, he interacted with the women and children encircling him. The abnormal exhibit was safe for families posing no threat to their values or sensibilities.

\footnotetext{
${ }^{18}$ Rachel Adams, quoted in http://www.common-place.org/vol-04/no-02/adams/. (accessed on Friday. August 14, 2015).
} 


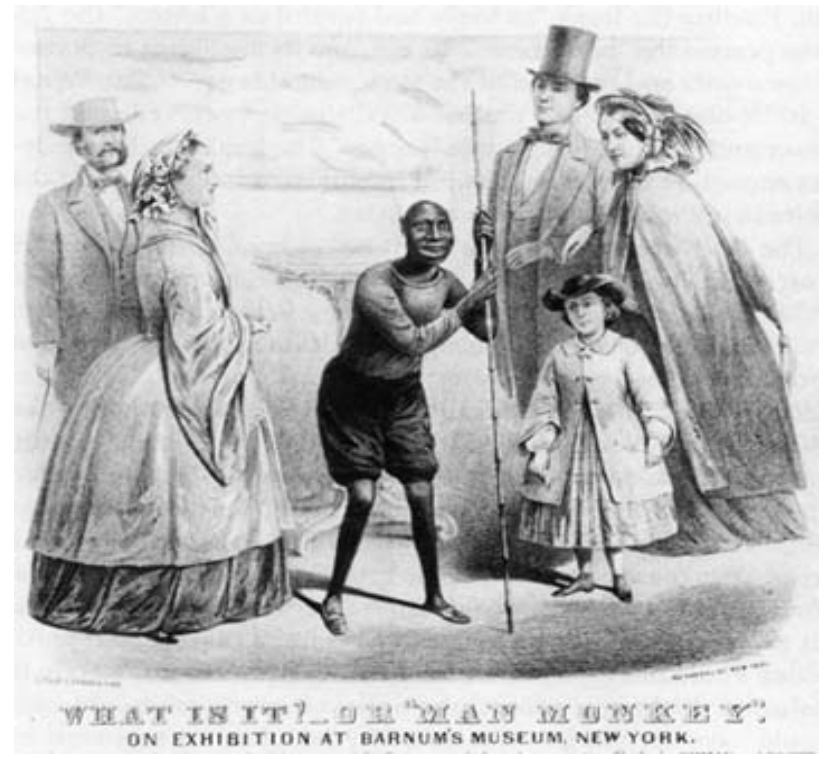

Barnum's exhibits extended beyond "living curiosities" to include humanesque creatures encased in glass. The Feejee Mermaid became an immediate hit among patrons, natural scientists, and journalists across the eastern seaboard. Newspapers described the display as "the very deucedest looking thing imaginable" the faux mermaid featured the withered body of a monkey with the desiccated tail of a fish and its incisors resembled fangs. Promotional boards and newspapers warned audiences of the grotesque appearance of the exhibit claiming, "the sight of the wonder has forever robbed us...of mermaid beauty. For the Feejee Mermaid is the very incarnation of ugliness."19

${ }^{19}$ Quoted in http://www.museumofhoaxes.com/hoax/archive/permalink/the feejee mermaid. 

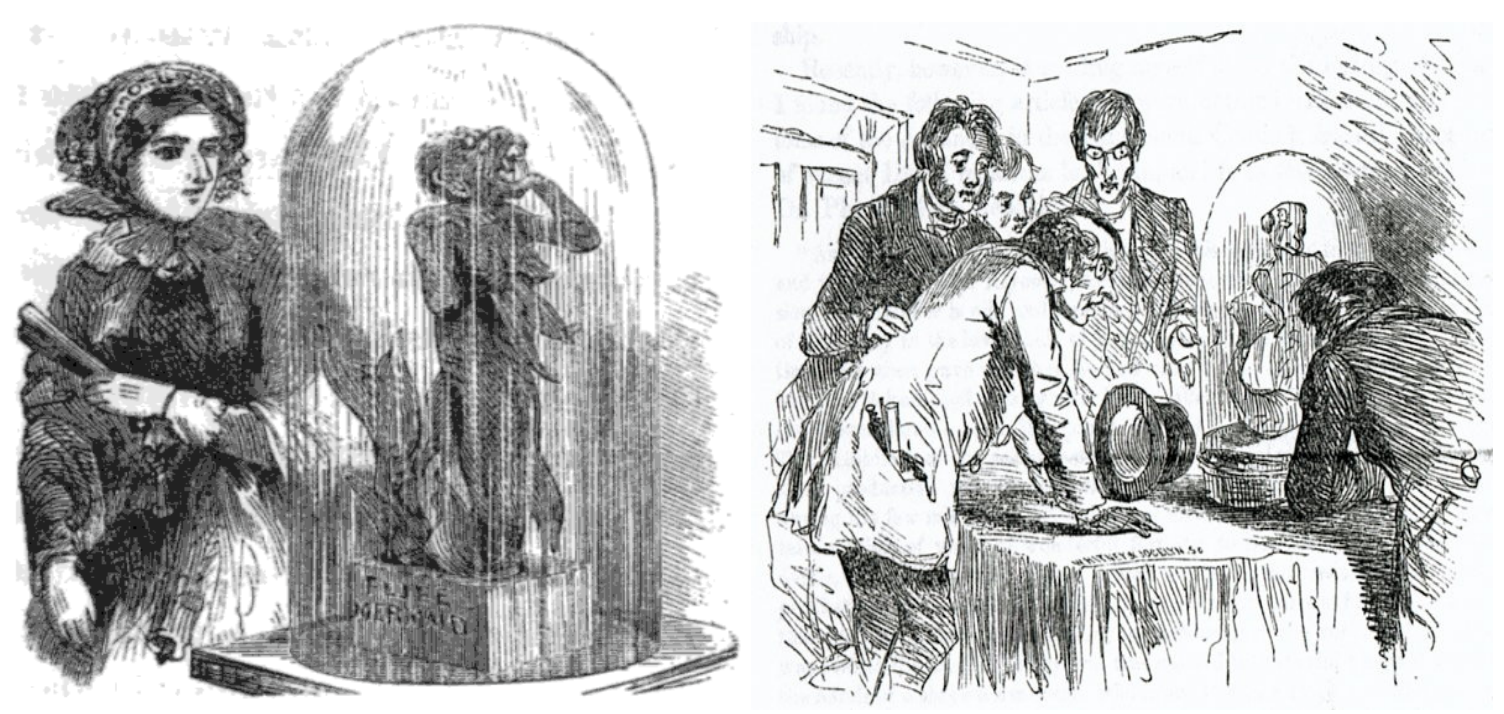

Advertisements emphasized the appropriateness of staring at the monstrous form. Aware of the cultural restraints placed on middle-class women, Barnum was careful to utilize illustrations that reflected interest rather than repugnance. Barnum also enlisted the help of journalists to promote the family friendly atmosphere of his exhibits during a tour throughout South Carolina. The Charleston Courier published a series of articles attesting to the appropriateness of the Feejee Mermaid. "The natural curiosities too are well worthy of a visit from the curious and scientific. The entire entertainment is an eminently successful one... and the delight it ministers to children is literally uproarious. $" 20$ The power of these advertisements spurred a desire that was often times difficult to resist. As the war progressed, these depictions held firm in the minds of citizens, so much so that ideas like humanitarianism and duty were quickly forgotten.

When the war first broke out, thousands answered Lincoln's call by volunteering for the army, joining benevolent associations, taking part in fundraising campaigns, and offering medical expertise. Massachusetts alone sent three regiments to Washington just

20 “The Exhibition at the Masonic Hall," Charleston Courier, January 21, 1843. 
days after the firing on Fort Sumter. Throughout the lifespan of the war thousands of women worked as nurses in hospitals and transport vessels. Scattered across the northern states, many congregated in major cities before making their way to the front lines. One such nurse remarked on the powerful draw of Barnum's exhibits upon those first entering the city. "We were all disgusted with a young surgeon in the cars yesterday, who was ordered to Gettysburg without delay. He was thoroughly indifferent, and said 'he was not going to kill himself hunting transportation; he would go to Barnum's and take it easy and go in the morning."21 Even the harrowing events at Gettysburg could not persuade some to maintain their obligations.

The link between Barnumesque exhibits and Civil War soldiers could, at times, become blurred. In the weeks following the battle of Gettysburg tens of thousands of wounded soldiers were transported by wagon to depots set to take them north. As the Ambulance made camp in Taneytown, Pennsylvania, crowds of local citizens visited the site hoping to catch a glimpse of injured soldiers. One Ambulance Corps member vividly recalled the feeling of exhibitionism. "We all take a bath in a little creek which runs near where we are encamped but hardly have a chance as the whole population of the place came to see us, as if we were a traveling museum."22 As we can see, the relationship between disabled soldier and a museum display were often times conflated.

\section{The Advent of War: Soldiers, Anatomy, and Museums}

\footnotetext{
${ }^{21}$ Emily Souder, Leaves from the Battlefield of Gettysburg: A Series of Letters from a Field Hospital, 14.

${ }^{22}$ Coco, 169; Heyward Emmell, The Civil War Journal of Heyward Emmell, Ambulance Corps: A Very Disagreeable War, ed., Jim Malcolm (Madison: Fairleigh Dickinson University Press, 2011), June 29,1863, 73.
} 
All throughout the North, citizens and soldiers took part in an ongoing discourse over the display of human bodies. Northerners did not have to wait long before museums began to mirror what one could find on the battlefield. Urban residents who did not have the money or the luxury of following the Union army in search of a visual connection to the war could turn to a number of new commercial venues springing up in city centers. Anatomical museums, a cousin of the dime museum, focused its energy on the display of medical abnormalities and curious injuries, while combining the respectability of the scientific and medical field with the curiousness of the dime museum. The anatomical museum focused less on humbug embellishments and more on pathological and biological human specimens. Two anatomical museums in particular discovered that the war, quite naturally, piqued interest in bodily exhibits. In an effort to build upon this curiosity, the College of Physicians in Philadelphia, as well as the United States government, took parallel roads in the collection and exhibition of human remains. Each catering to a different audience, they both became important and popular centers for the scientific and the macabre.

Philadelphia's Mütter Museum and the federally sponsored Army Medical Museum opened their doors to the public during the war years. Aware of the lowbrow reputation of dime museums, they both made legitimate claims about the appropriateness of viewing human bodies, even those deformed by war. Chief among their claims was that specimens should always be viewed for educational enlightenment only. It was with this in mind that these two museums began the exhibition of "morbid specimens" aimed at educating, titillating, and shocking its visitors, which continues to this day. 


\section{The Mütter Museum: Philadelphia's Premier Medical Oddities Museum}

When Thomas Dent Mütter bequeathed his personal collection of morbid anatomy to Philadelphia's College of Physicians in 1859, he could not have guessed that his curiosities would still be drawing crowds one hundred and fifty years later. Born in 1811, Mütter took part in America's transition from the medical dark ages to the forefront of cutting-edge technology, research, and practice. From modest beginnings, Mütter traveled to Paris, France, to learn of the progressive surgical techniques being performed there with the hopes of returning home and starting his own practice. ${ }^{23}$ While there, he learned of a new, rather avant-garde, field of surgery referred to as les opérations plastiques, or plastic surgery. What fascinated him most about this new field was its ability to provide a better life for so-called "monsters." Monster was a popular term used to describe "unfortunates" or "regrettables." They typically featured some kind of deformity such as cleft palate, severe burns (an all too common occurrence for women), battlefield injuries, industrial accidents, or any number of birth defects. Often times the only viable form of employment for unfortunates were traveling sideshows, which only heightened their deformities. However, les opérations plastiques, with its ability to fuse cleft palates together and replace burned skin with healthy grafts, promised, not just to save lives, but also to improve them. After studying in Paris' esteemed Hôtel-Dieu, Mütter returned home to open his own private practice in Philadelphia. ${ }^{24}$

\footnotetext{
${ }^{23}$ During the mid nineteenth-century Paris, France, was considered the worldwide Mecca of medical enlightenment due to their prodigious experiments and early forays into plastic surgery.

${ }^{24}$ Cristin O'Keefe Aptowicz, Dr. Mütter's Marvels: A True Tale of Intrigue and Innovation at the Dawn of Modern Medicine (Gotham Books: New York City, 2014).
} 
Mütter's, la chirurgie radicale ${ }^{25}$ quickly earned him a reputation as a master surgeon in Philadelphia, and he soon took over as chair of surgery at Thomas Jefferson Medical College. Mütter received the position in 1841, after the college ousted one of its founding members, George McClellan, father of the famed Civil War general. Only thirty years old, Mütter continued to serve as chair for fifteen years until failing health forced him to resign his position. His tenure, however, was not without controversy. Mütter was typically at odds with his more conservative colleagues regarding hygiene, post treatment recovery space, and the use of anesthetics. Throughout his illustrious career he amassed a large collection of anatomical oddities, specimens, and wax replicas, one which included a 9.8" curved, brown horn that grew out of an unfortunate's forehead. ${ }^{26}$ By the end of his life, Mütter's private collection numbered over 1,700 curiosities; he was just forty-seven.

The Mütter Museum officially opened 1863, amidst the harrowing stories of wartime death and deformity. Along with the specimens, Mütter donated $\$ 30,000$ "for the services of a curator, for an honorarium for a yearly lecturer and for enlarging and maintaining the museum." ${ }^{27}$ The purpose of the museum was to advance the science of medicine and "to thereby lessen human misery." The focus on education was a common element of anatomical museums all throughout this period as medical colleges sought to gain more esteem with their collection of curiosities. Though the collection limited access to medical students early on, the museum later opened its doors to the broader public. The museum has expanded greatly since its opening, adding over 25,000 objects

\footnotetext{
${ }^{25}$ Translation: radical surgery.

${ }^{26}$ The wax replica of Madame Dimanche's horn is still on display at the Mütter Museum.

${ }^{27}$ Ellen Wade, A Curator's Story of the Mütter Museum and College Collections (1974), quoted in Aptowicze, 283.
} 
to their collection, including the Soap Lady, the famous Hyrtl skull collection, and a piece of Albert Einstein's brain. ${ }^{28}$

The display of morbid anatomy was often viewed as salacious in nature.

Therefore, medical colleges focused on creating an aura of respectability around its exhibits. $^{29}$ To do so, the governing board emulated its European cousins in specimen and presentation. Much of the museum's early expenditures were spent on advertising efforts aimed at enticing Philadelphia's medical community. In January of 1864, the museum published a catalogue of their exhibits stylized after the famous Guy's Hospital in London. One of the largest teaching hospitals in the world, Guy's opened in 1721 as a sanctuary for monsters and "incurables." Though the infirmary eventually grew into a general hospital, Guy's continued to specialize in unfortunates refused treatment at other medical centers. As an educational center, Guy's contained a well-respected collection of morbid anatomy, one in which the Mütter Museum was quick to imitate. "I herewith endure a new catalogue of the Mütter Museum (the arrangement adopted is substantially the same as that of the Guy Hospital Museum)." The catalogue included a list of eighteen digestive organs, over sixty wax replicas of dried infections, and various jarred tumors and oddities. ${ }^{30}$

The Mütter Museum continued to add to its collections throughout the war. Wet and dried "morbid specimens" along with diseased bones from the battlefield were especially desirable. The relevancy of the museum relied upon a continuous stream of exhibits that illustrated modern surgical techniques or featured medical anomalies. However, competition from rival museums added a layer of complexity to the

\footnotetext{
${ }^{28}$ The Hyrkl collection contains 139 skulls of various ethnicities. http://muttermuseum.org/about/history/

${ }^{29}$ Some of the most popular displays consisted of female genitalia.

${ }^{30}$ Report, Jan, 6, 1864, Morton, T.G. to the Museum Committee, Mütter Museum.
} 
procurement of displays, forcing the governing committee to reach out to the medical community to help increase its stock of abnormal and curious specimens. When donations from private collectors failed to meet demand, the committee published regional circulars promising permanent preservation of specimens as well as personal recognition.

Hall of the College of Physicians,

N.E. corner of Thirteenth and Locust St.

The Museum Committee of the College of Physicians having in charge the Pathological Museum of the late Dr. Mutter, desire to add to it such Anatomical and Pathological specimens of interest as are now in the hands of physicians, or such as may be met with in their practice.

The Committee therefore solicit donations, which in every instance should be accompanied by a history of the case, or a reference to a medical journal will be labeled with the donor's name, and placed in the Museum for permanent preservation.

Specimens addressed to the Curator may at any time be sent to the Hall of College of Physicians

\author{
J.R. Paul, MD \\ WM Hunt MD \\ S. Weir Mitchell MD \\ Philadelphia, Nov. 1865
}

Throughout the second half of the nineteenth century, anatomical museums continued to outbid one another for sensational exhibits. Mütter's lost out on one esteemed collection to the Army Medical Museum that contained battlefield specimens from Waterloo. The collection included "every known fracture + disease of bone + showing the powers of nature in the repair." Aside from its historical significance, the pieces illustrated the practice of early nineteenth century battlefield medicine. "The collection would be of great importance in filling a gap in the Army Medical Museum which must necessarily exist (ie) showing reunion after fracture, saber cuts, + repair from disease." ${ }^{\text {31 }}$ The loss stung the Philadelphia-based museum all the more due to its local ties; the collection came from Prof. William Gibson, Emeritus Professor of Surgery at the University of

\footnotetext{
${ }^{31}$ Bvt. Maj. Asst Surgeon John H Janeway to Bvt. Maj. Asst Surgeon A.A. Woodhull, Jan. 6, 1866, Mütter Museum.
} 
Pennsylvania. Henceforth, the governing committee set aside a sizable fund for the purchase of complete collections. "Whilst the committee deemed it an advantage to have on hand such a fund as would enable it to buy an entire collection should any offer, it is not its wish to accumulate the income by withholding it when judicious opportunities offer for making purchases. A few years since the collection of the late Prof Gibson, which contained a number of fine specimens, was lost to the College because your Committee had not the funds sufficient to bid for the entire collection in competition with the Surgeon General's office." ${ }^{, 2}$

In the twenty-four months following the creation of the fund, the museum made two sizable additions to its collection. The first involved an anatomical cast of Siamese twins, Chang and Eng, who became a worldwide sensation in the mid nineteenth century. Their popularity drew huge crowds as curious men and women from all social classes flocked to gape at their conjoined bodies. Added to these abnormal bodies existed a layer of salaciousness as visitors learned of the twenty-one children they fathered. ${ }^{33}$ The Mütter Museum was also able to purchase the notable Dr. Hyrtl collection, an assortment of 139 skulls representing various ethnic groups. The collection proved to be a boon to the reputation of the museum at a time when phrenology dominated the scientific community. Special attention was given to the representation of these skulls so they could be "mounted and exhibited in a manner which they will greatly increase its illustrative value. ${ }^{34}$

\footnotetext{
${ }^{32}$ Report, Jan. $1^{\text {st }}, 1873$ of the Commission on the Mutter Museum to the College of Physicians, Mütter Museum.

${ }^{33}$ Chang and Eng Bunker were born in Siam 1811. They came to America to take part in the flourishing freak show business. After amassing a large fortune they became slave owners in the south. In 1843, they married sisters and fathered twenty one children.

${ }^{34}$ Report, Jan. $3^{\text {rd, }} 1866$ - of the Commission on the Mutter Museum to the College of Physicians, Mütter Museum.
} 
Unfortunately, the Mütter Museum found it difficult to attract medical professionals early on despite its ability to boast some of the most prized collections in the United States. "The museum has been open on stated afternoons for the admission of graduates and students, as yet not many have availed themselves of the opportunities offered, but the committee hope by judicious purchases of preparations at home and abroad and by donations to greatly increase the attractions of the collection and to make it practically serve all the intentions of its founder." 35 It was not until the museum began exhibiting Barnumesque exhibits like Chang and Eng and the Hyrtl Skull collection that attendance increased to a few hundred visitors per year. The 1887 , yearly report made note of the increase, "during the year the number of visitors has been very great compared with previous years." 36

In 1875, the Mütter Museum turned its attention toward maximizing the impact of their displays while making sure to limit their visibility from non-paying customers. The governing committee itself made note of the rather embarrassing state of the building. Curious Philadelphians knew they could satisfy their desire for abnormality simply by peering through the museum's windows. "The Committee regret the crowded state of the museum, the unsuitableness of the rooms, owing to their position being on the ground floor exposing the museum too much to public gaze, the want of light and wall space and cannot conclude without urging the College the necessity of providing a third story especially constructed with skylights, for the museum." Aside from eliminating the street side peep show, the museum sought improved accommodations for the dissections and

\footnotetext{
${ }^{35}$ Report, Jan. $2^{\text {nd }}, 1867$ - of the Commission on the Mutter Museum to the College of Physicians, Mütter Museum.

${ }^{36}$ Report, December 7, 1887 - of the Commission on the Mutter Museum to the College of Physicians, Mütter Museum. The museum is now open to the public and boasts 60,000 visitors a year.
} 
specimen preparations. "The inadequate accommodations for the preparing of specimens is a serious inconvenience causing the museum to be used, at times, for the purposes of common dissecting rooms and often to appear in a dirty and disorderly condition."37

From its inception, the Mütter Museum helped to legitimate the display of medical anomalies. By tapping into the entertainment culture that Barnumesque displays cultivated in the antebellum period, anatomical museums were able to entice medical practitioners through its doors. Morbid specimens like tumors, diseased bones, and specimens from the battlefield existed along side sensationalized exhibits such as a 40pound colon and "The Soap Lady." ${ }^{8}$ Taken alongside the popularization of measurement and statistical analysis these exhibits helped to narrate the historical construct of normality and deformity. The Hyrtl Skull collection, for example, provided a scientific basis for the measurement of crania from dozens of races and ethnicities from across the globe, which only enhanced the idealized notion of "normal." The Mütter Museum was not the only anatomical museum to place bodies on display beginning in the war period. One museum, in particular, focused its exhibits around the war's transformative effects on soldier's bodies.

\section{Army Medical Museum: Soldier's Bodies and Display}

Citizens who wanted to see destroyed bodies did not need to follow on the heels of marching armies, nor did they have to brave the dangers of hospitals and camps.

\footnotetext{
${ }^{37}$ Report, Jan. 6, 1875 - of the Commission on the Mutter Museum to the College of Physicians, Mütter Museum.

${ }^{38}$ The 40-pound colon belonged to a sideshow performer who also went by the name The Human Windbag. The Soap Lady was unearthed accidentally during a construction project in 1875 . Due to the high presence of moisture and bacteria in the soil the fatty acids in her body turned into a type of glycerol. Both exhibits can still be seen at the Mütter Museum.
} 
Early in the war military officials and the public were already aware of stories surrounding injured soldiers. The sheer volume of wounded and diseased men provided battlefield surgeons with ample opportunity for experimentation and education. Under the direction of Surgeon General William Alexander Hammond, the Union Medical Department believed that these bodies could have an overall generative effect on the medical field if they could be collected and systematized. On May 21, 1862, Hammond issued his Circular No. 2, which provided for the establishment of the Army Medical Museum. The stated purpose of the museum was for "illustrating the injuries and diseases that produce death or disability during the war, and thus affording materials for precise methods of study or problems regarding the diminution of mortality and alleviation of suffering in the armies. ${ }^{39}$ Assistant surgeon Harvey E. Brown noted, "Hardly ever in the history of the world had such an opportunity been offered for the collection of statistics upon all points of military medicine, surgery and hygiene, and of obtaining specimens illustrative of pathological anatomy." 40 Hammond's AMM, which began as a necessity of war, soon laid the foundations for major reform in American medicine.

Like other anatomical museums of the period, the Army Medical Museum promoted medical enlightenment. Its collections were to serve as a center for research as well as a demonstration of advancements made in science and medicine. No longer satisfied with the worldwide stigma of medical backwardness, the museum was to be a shining example of America's rise to respectability. However, the AMM was different

\footnotetext{
${ }^{39}$ George A. Otis, "Notes on the Contributions of the Army Medical Museum," Feb. 7, 1878, Special Scientific and Historical Reports, 1814-1919, file A, no. 41, entry 629, RG 94, National Archives and Records Administration.

${ }^{40}$ Daniel Lamb, A History of the United States Army Medical Museum, 1862-1917, unpublished.
} 
from other anatomical museums in important ways. First, the AMM opened to the general public ensuring that the museum would operate as both an education space and entertainment venue. Visitors could examine specimens of disease, bones displaying gunshot wounds, and various skull injuries. The museum's microscopial collection was even available to laymen. On the whole, the collection was described as, "one which was not surpassed anywhere not even in the medical schools of Paris." ${ }^{\not 1}$ By giving unrestricted access to soldier's bodies the federal government gave the public full license to gaze, gawk, study, and satisfy one's morbid curiosity. If Northern citizens truly felt that the war's suffering belonged to them, then the Army Medical Museum served as the tangible representation of that ownership. ${ }^{42}$

Secondly, despite its open admission, the museum continued to exhibit specimens with medical jargon. Visitors drawn to John Wilkes Booth's spinal cord could read the following; "[the cervical region is] transversely perforated from right to left by carbine bullet, which fractured the laminae of the fourth and fifth vertebrae." ${ }^{43}$ The AMM hoped that by using scientific terminology they could control the discursive representation of their specimens while also maintaining a sense of transparency with the pubic. The museum's curators were careful to frame the exhibits as "important national contributions," not merely trophies of war. ${ }^{44}$

The Army Medical Museum itself was the brainchild of William Alexander Hammond who wanted to preserve and collect specimens for posterity. According to

\footnotetext{
${ }^{41}$ Shauna Devine, Learning from the Wounded: The Civil War and the Rise of American Medical Science (Chapel Hill: University of Chapel Hill, 2014), 180-181.

${ }^{42}$ Frances Clarke, War Stories: Suffering and Sacrifice in the Civil War North (Chicago: University of Chicago Press, 2011), 80.

${ }^{43}$ Devine, $180-181$.

${ }^{44}$ Devine, 180.
} 
Brown, "very soon after his appointment, Surgeon General William Hammond saw the great scientific advantage that would accrue to the cause of scientific medicine and surgery by rendering the enormous experience of the war available for future study. ${ }^{, 45}$ As curator, Hammond appointed a young and well-respected surgeon named John H. Brinton. ${ }^{46}$ In his famed Circular No. 2 Hammond petitioned medical officers to send interesting medical specimens, along with written case histories, to Brinton for the museum's collections.

Circular No 2. Surgeon General's Office

Washington D.C., May 21, 1862

As it is proposed to establish in Washington, an Army Medical Museum, medical officers are directed diligently to collect and to forward to the office of the Surgeon General, all specimens of morbid anatomy, surgical and medical, with may be regarded as valuable; together with projectiles and foreign bodies removed, and such other matters as may prove of interest in the study of military medicine or surgery. These objects should be accompanied by short explanatory notes. Each specimen in the collection will have appended the name of the Medical Officer by whom it was prepared.

WILLIAM A. HAMMOND, Surgeon General.

However, some surgeons found it difficult to write extensive reports in the aftermath of battle. A field hospital was arguably the worst place to be after the guns stopped firing. Surgeons performed their duty amid screams of the injured surrounded by pools of blood and mounds of orphaned appendages. The acrid scent of festering wounds turned many would-be volunteers away. Everywhere one looked, nurses, chaplains, and gawkers rushed from one horrific scene to the next. Often surgeons did not rest for days

\footnotetext{
${ }^{45}$ Harvey E. Brown, Medical Department of the U.S. Army from 1775 - 1883, 225.

${ }^{46} \mathrm{John} \mathrm{H}$. Brinton was a rather well connected surgeon during the war period. He had previously studied under Thomas Dent Mütter, who had displaced his uncle George McClellan as chair of surgery at Thomas Jefferson Medical College. His cousin was famed Union general George Brinton McClellan. After the war Brinton went on to become a well-regarded professor at Jefferson, while also serving on the governing board of the Mütter Museum.
} 
at a time, constantly employed at staving off disease or death. Medical practitioners simply did not have the time to clean, catalogue, and write descriptive accounts of each curious wound and treatment procedure, nor were they particularly incentivized. Brinton himself attested to these difficulties, "it was at first difficult to get our system to work...it was hard enough to be worked day and night in those great surgical emergencies, accompanying fierce protracted battles, and it really seemed unjust to expect the rough preparation, necessary to preserve for the Museum, the mutilated limbs." Early on Brinton had to collect specimens himself. "Many and many a putrid heap have I dug out of the trenches where they had been buried, ... and ghoul-like work have I done, amid surrounding gatherings of wondering surgeons, and scarcely less wondering doctors." Despite the rather difficult and gruesome task, Brinton believed in the importance of the Museum. "My whole heart was in the museum, and I felt that if the medical officers in the field, and those in charge of hospitals, could only be fairly interested, its growth would be rapid." Other difficulties arose due to the common practice of selling or collecting specimens for personal collections. One such surgeon faced military discipline for selling battlefield specimens to a private collector instead of sending the piece to the AMM. Much as Thomas Dent Mütter had done, Civil War surgeons wanted to add curious cases to their own private collections. These collections, known as curiosity cabinets, were used to showcase the skills of a surgeon to potential patients. Keeping in line with the medical customs of the nineteenth-century, many surgeons felt they had a right to morbid specimens. ${ }^{48}$

\footnotetext{
47 Brinton, Personal Memoirs, Personal Memoirs of John H. Brinton: Civil War Surgeon, 1861-1865, ed., John S Haller Jr., (Carbondale: Southern Illinois University Press, 1996), 187.

${ }^{48}$ Ann Fabian, The Skull Collector: Race, Science, and America's Unburied Dead (Chicago: University of Chicago Press, 2010).
} 
While most Civil War surgeons recognized the importance of the collection project, others were indifferent or outright refused to preserve specimens. "Many of our Army Surgeons entered into the scheme of the Museum with great zeal and earnestness, but some few there were, and these were mostly the least educated, who failed to see its importance." ${ }^{49}$ In response to tepid surgeons, Hammond issued a second circular that made use of the full weight of the military. On August 10, 1862, he issued Circular No. 10 in which he noted that "many medical officers, both regular and volunteers have partially disregarded previous circulars from this office. These circulars are explanatory orders and in future, officers neglecting to comply with their directions will be proceeded against for disobedience of orders. ${ }^{, 50}$ Despite the language of the circular, Hammond's goal was active cooperation rather than hard discipline. Shortly before the threat of military discipline Hammond issued a circular aimed at playing upon the vanity medical practitioners. Circular No. 5 promised that all contributing case studies would be published in the Museum Catalogue and the Medical and Surgical History of the War of the Rebellion currently under works. In addition, there existed the possibility that contributions from the battlefield would draw the interest of national and international medical journals. "It is therefore confidently expected that no one will neglect this opportunity of advancing the honor of service, the cause of humanity, and his own reputation." 51 Brinton followed up on Hammond's promise in the first edition of the AMM's catalogue. Though Brinton himself had collected many of the original

\footnotetext{
${ }^{49}$ Brinton, 187.

${ }^{50}$ Circular No. 10, issued August 10, 1862, Washington D.C., Circulars and Circular Letters of the Surgeon General's Office, 1861-1885, p.58, entry 63, RG 112 National Archives and Records Administration.

${ }^{51}$ Quoted in Devine, 31. Circular No. 5, issued June 9, 1862, Washington D.C., Circulars and Circular Letters of the Surgeon General's Office, 1861-1885, 58, entry 38, RG 112 National Archives and Records Administration.
} 
specimens, he was careful to give credit to the surgeon or doctor who provided the medical treatment. "Very many specimens I had brought there from the battle-fields, collected by myself. These I put in a catalogue, assigning them to such medical officers, as I could call to mind, and especially to those whom I knew to be lukewarm in the Museum interests. The effect of the procedure was good." 52 The impact of these circulars could be seen almost immediately. With the opportunity to distinguish themselves in the medical field the Museum soon found wide support throughout the Union army.

The museum opened to wide public acclaim attracting a swarm of visitors through its doors. It was little surprise to John H. Brinton that the museum was an instant success. "As soon as the Museum was fairly established in its home, it began to attract attention. The public came to see the bones, attracted by a new sensation." ${ }^{, 53}$ The opportunity to see medical oddities and human remains in a respectable and sterile environment proved to be a social windfall for the military. The increased number of bodies and anatomical matter produced by the war helped to usher forth-changing attitudes on death and disability. Historian Shauna Devine states that injury and death "became almost completely associated with scientific medicine, and this interest was fostered through the Army Medical Museum." The public, who contributed to the social discourse through sentimentalized literature, believed that the war's suffering belonged to them. As a federally funded entity, the AMM was a "common possession," a shared reminder of the North's losses and gains. The exhibits on display also acted as a siphon through which the public recognized the benefits of understanding human anatomy. By

\footnotetext{
${ }^{52}$ Brinton, 188.

${ }^{53}$ Brinton, 189.
} 
1865 most citizens had changed their stance on dissection and medical experimentation. Through the lens of scientific medicine, "the public came to expect more from its physicians. ${ }^{54}$

The opportunity to take part in the latest national sensation drew thousands of citizens to the museum. It was not long before the museum required a larger space to accommodate the increasing number of tourists and the influx of new specimens. In 1866, the museum relocated to Ford's Theatre building, which only heightened its appeal. "With the removal of Ford's Theater and its tragic associations, with the great appealing figure of Lincoln, the number of visitors mounted to such an extent that rules, approved...by the Surgeon General, were posted." These rules permanently extended the hours of operation in addition to opening the museum on Saturdays. The overlap of theatrical and museum entertainment was not lost on the public. It was apropos perhaps that visitors could inspect the spinal marrow of John Wilkes Booth in the very building where he assassinated Lincoln. By 1871, nearly 18,000 people toured the museum annually. During Ulysses S. Grant's inauguration the throng of visitors forced the AMM to increase its hours. Travel guides and city maps recognized the Army Medical Museum as one of the "sights" of Washington D.C. Noted poet and journalist Mary Clemmer Ames wrote of the AMM in her popular book Ten Years in Washington: Life and Scenes in the National Capital. Due to the origins of the exhibits she believed that the museum

\footnotetext{
${ }^{54}$ For more on the cultural impact of death see Drew Gilpen Faust, This Republic of Suffering: Death and the American Civil War (New York: Vintage Books, 2008); Alice Fahs, The Imagined Civil War: Popular Literature in the North and South, 1861-1865 (Chapel Hill: University of Chapel Hill, 2002); Frances Clarke, War Stories: Suffering and Sacrifice in the Civil War North, (Chicago, University of Chicago press, 2011); Devine, 179, 183.
} 
must "never be a popular place to visit," though she could not deny that it was "the most interesting" place in the city. ${ }^{55}$

As a repository of soldier's remains, the museum attracted nearly as many veterans as citizens. Some went to take in the sights as tourists while others were drawn toward the AMM's scientific endeavors. Among these visitors, however, there existed veterans who were looking for their own orphaned appendages. Soldiers took pride in their national contributions and took great pleasure in showing their mounted "donations" to family and friends. "I remember once seeing a florid-looking officer," recalled Brinton, "a Colonel, I think, with a slight limp, busily hunting up a leg bone with a certain number, in the glass case. He evidently found what he wanted, and suddenly turning to a buxom-looking young woman at the other end of the room, he called to her in great glee 'Come here, Julia, come here - here it is, my leg! And nicely fixed up too.",56 To be displayed behind glass cases became something of a phenomenon. Union veteran Lorin Leray wrote the museum in 1883, inquiring after his limb. "Nineteen years ago, Surgeon A.J. Bartlett $33^{\text {rd }}$ Minn., removed the head of the humerus from my left arm. He writes me that he sent the bone with a minie ball sticking in it to the Army Medical Museum at Washington - it is numbered 6599 in the surgical section. I have never seen the piece removed. Will you kindly have the bone with the ball in it photographed and sent to me? I will be glad to incur all the necessary expense. I hope you will do this as it will be a valuable war relic to me." ${ }^{57}$ In an address to the Army Medical School's graduating class, Brinton recalled another amusing anecdote. While working in the

\footnotetext{
55 Ames, Ten Years in Washington, 477.

${ }^{56}$ Brinton, 190

${ }^{57}$ Letter, Lorin Leray, Dec. 29, 1883, Incoming Correspondence, RG 13 OHA, National Museum of Heath and Medicine.
} 
AMM during the summer of 1863 , an extemporized coffin unexpectedly showed up at his office door. Upon investigation, he discovered a visiting card tacked onto the repository, it read "with compliments of Major General D.E.S." The infamous Daniel Sickles had just donated his own leg. Soldiers often felt a strong attachment to their missing limb and frequently visited their body parts when able. Dan Sickles was known to sit next to his exhibited leg on the anniversary of its amputation. An Appleton's Journal entry noted that an orderly of the museum whose right arm "from the shoulder blade to the elbow" was displayed "has the satisfaction - if satisfaction it is - to be able to go and take a look at it everyday." 58

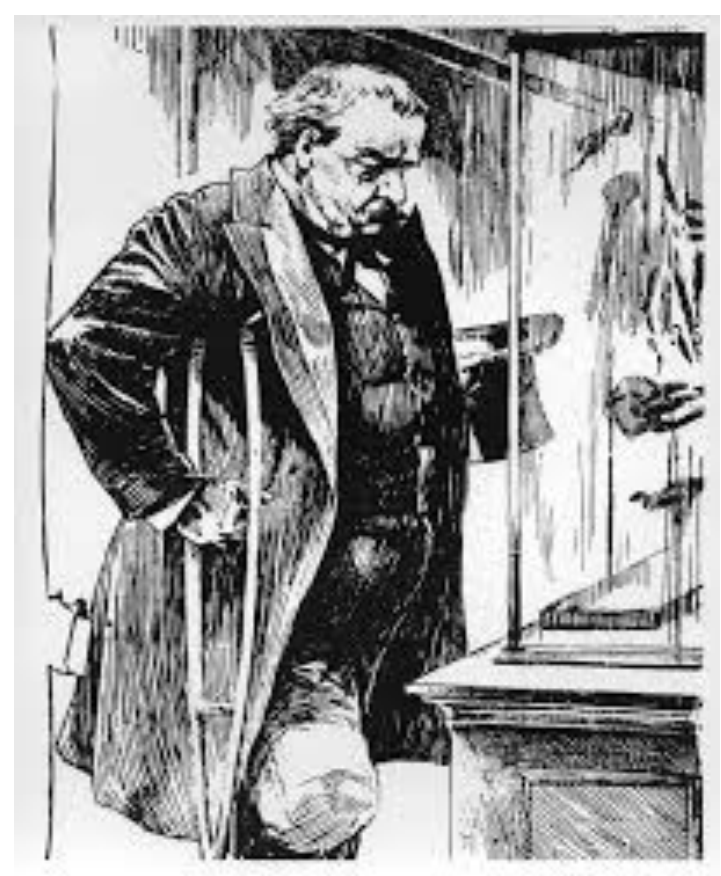

The Civil War brought about new questions concerning ownership-based rights of anatomical remains. In the antebellum period, dead bodies customarily belonged to the family of the deceased. The notion of dissection or anatomical experiments on dead

\footnotetext{
${ }^{58}$ Louis Bagger, “The Army Medical Museum in Washington” Appleton's Journal 9 (March 1, 1873): 294297.
} 
bodies, regardless of its scientific merits, was a contentious affair in the United States. Between 1785 and 1855 there were no less than seventeen "anatomy riots," in which outraged citizens reclaimed their dead. ${ }^{59}$ The possession of living bodies, however, was a rather common affair in the antebellum north. Ownership rights over the bodies of "living curiosities" strengthened as Barnumesque entertainment thrived. When Joice Heth, What Is It?, Chang and Eng, dog-faced boys, giants, midgets, and armless wonders signed contracts that gave show managers exclusive rights to exhibit their bodies, they lost control over their own corporal forms. Freak shows and dime museums could display "living curiosities" any way they wished. If these curiosities died while under contract, managers assumed that they retained control over the deceased body, regardless of the person's dying wish. Fearful of becoming scientific fodder, the 7'-7' Charles Byrne, "The Irish Giant," requested that he be buried at sea. After having spent a lifetime being exhibited and gawked at by the public, Byrne wished to find peace and anonymity in death. However, Byrne died at just 22 and his body was sold to the famed scientist and anatomist John Hunter, who boiled his body down to the skeleton and exhibited it in his collection. $^{60}$

There was a racial element to the collecting of skeletal remains as well. The collection of skulls became a popular venture in the antebellum period reaching its peak during the postwar years. Naturalists argued that their collections contributed to the scientific community by providing a host of skeletal remains from which analysts could draw comparisons. These works theorized inchoate ideas about the connection between

\footnotetext{
${ }^{59}$ Michael Sappol, A Traffic of Dead Bodies: Anatomy and Embodied Social Identity in Nineteenth-Century America (Princeton: Princeton University Press, 2002), 4.

${ }^{60}$ The body continues to be displayed at the Hunterian Museum at the Royal College of Surgeons in London, despite heavy protest from experts.
} 
anatomy and race, and inadvertently laid the foundation for the phrenology movement of the late nineteenth century. The measurement and categorization of racial skeletons fascinated collectors, especially crania. They compared, measured, and analyzed the remains of most races, except those of white Americans, which were difficult to obtain due to social and cultural taboos.

American skull collectors were not alone in their zeal for human remains. Europeans had a long history of trading, selling, and purchasing the remains of ethnic and racial bones for the purpose of study and exhibition. Samuel George Morton epitomized the American skull collector. Born in Philadelphia to a Quaker family, Morton served as a professor of anatomy at Pennsylvania Medical College during the antebellum period. He spent a lifetime collecting morbid remains, especially Native American crania, a process that earned him the moniker the "American Golgotha." from as far away as Africa and Fiji to go along with his Native American collection. His work is largely credited with the founding of the "American School" of ethnography, which sought to distinguish different species of humans based on cranial measurements. Morton claimed he could determine intellectual ability through skull size, the larger the cranium the higher the intellectual aptitude. Though Morton sought to "strip collected skulls of symbolic meaning" his work was later adapted for use in scientific racism. ${ }^{62}$

Morton was not alone in his collection of racial and ethnic remains, such behavior not uncommon for American medical students who had difficulty obtaining corpses for anatomical study. Dr. Charles Hentz noted his own enthusiasm for collecting specimens. In his autobiography he recalled receiving the "body of a little dead negro baby" wrapped

\footnotetext{
${ }^{61}$ Fabian, The Skull Collectors.

${ }^{62}$ Ibid, 4.
} 
in a newspaper "born dead - shriveled like a mummy" as a gift for his help in a grave robbing scheme that included the theft of a young German woman's body. He secretly placed his "appropriate present" in his personal collection. ${ }^{63}$

The war brought an abundance of white American specimens into the collection market. The profusion of dead and wounded bodies made it much easier for craniologists to obtain white specimens. Building off the measurement techniques of men like Morton, Historian Ann Fabian notes that the "wartime impulse to measure bodies and the postwar push to sort corpses" had a drastic impact on whether bodies were displayed, collected, or reburied. The Army Medical Museum itself turned toward the collection of racial remains after it had exhausted its supply of war related oddities. In the 1870s the AMM had a strong supply of Native American crania from a various tribes, brought to them mostly from the conflicts on the western plains. French ministers were even allowed to make plaster casts of "Indian crania" to send back home. In 1892, the AMM assembled crania species to be displayed at the Columbian Exposition in Madrid, Spain. The collection consisted of "Indian crania and photography." Race and the collection of human remains became a vibrant theme in the second half of the nineteenth century thanks to the work done by wartime measurement. ${ }^{64}$

Hammond and Brinton were cognizant of the legal difficulties in collecting the body parts of white Americans who fought for the Union. "[It is] no easy matter to popularize the surrender to the Surgeon General's Office of human specimens." ${ }^{.65}$ It was the war itself, and the military bureaucracy, that provided the impetus for federal control

\footnotetext{
${ }^{63}$ Charles A. Hentz, Hentz Family Papers, Folder 23, Southern Historical Collection.

${ }^{64}$ Ann Fabian, The Skull Collectors, 5; Lamb, 54.

${ }^{65}$ John H. Brinton, "Address to the Members of the Graduating Class of the Army Museum: Closing Exercises of the Session 1895-96, Army Medical School," 599-605, John H. Brinton Manuscript Collection, box 1, RG 124, OHA, National Museum of Heath and Medicine.
} 
of soldier's bodies. To ensure the growth of its collection the AMM replicated the idea of contract status and body ownership popular in antebellum freak shows and dime museums. In the Surgeon General's estimation, men who signed up for the war effectively gave their bodies to the federal government. Federally controlled bodies were already a recognizable part of military life all throughout the Union army. Soldiers could be commanded, punished, and court marshaled at will; even beyond the military, citizens were under threat of losing rights to their bodies through the suspension of habeas corpus and the Conscription Act of $1863{ }^{66}$ The project organizers of the AMM laid claim to soldier's remains based its importance to the national advancement of medical science. The study of anatomical remains "became the concrete a priori of medical experience...it could detach itself from counter-nature and become embodied in the living bodies of individuals. ${ }^{\circ 7}$ Put simply, the study of soldier's bodies would directly aid the life of future Americans.

Despite the enthusiasm of some veteran contributors the AMM often found itself disputing with veterans over ownership rights. Brinton recalled one instance when a disabled veteran demanded the return of his limb. The curator firmly stated that military would not relinquish "the member in question." "But its mine, part of myself" the former soldier pleaded, to which Brinton replied, "to surrender a specimen [is] very much like yielding a principle," and promptly turned the soldier away. ${ }^{68}$ In another instance a soldier visiting the museum stated that a particular limb on display belonged to him and

\footnotetext{
${ }^{66}$ The Conscription Act of 1863, was the first war draft in the United States that included federal penalties for noncompliance.

${ }^{67}$ Devine, 188.

${ }^{68}$ John H. Brinton, "Address to the Members of the Graduating Class of the Army Museum: Closing Exercises of the Session 1895-96, Army Medical School," 599-605, John H. Brinton Manuscript Collection, box 1, RG 124, OHA, National Museum of Heath and Medicine.
} 
that he wished to take it back home. The curator had an ingenious way of resolving the situation, "on another occasion, a soldier, a private, came, examined the Museum, and with the help of the Assistant Curator, found his amputated limb." The disabled veteran surprised Brinton by arguing that his limb should belong to him. "It seemed to him his own property and he demanded it noisily and pertinaciously. He was deaf to reason, and was only silenced by the question of the Curator, 'For how long did you enlist, for three years of the war?' The answer was 'For the war.' The United States government is entitled to all of you until the expiration of the specified time. I dare not give a part of you up before. ${ }^{.69}$

The AMM was not the only museum to face criticism for its refusal to return bodies. The Mutter Museum experienced similar arguments over who owned the rights to specimens. In 1866, a donor named Dr. John Packard wanted a specimen he donated withdrawn from the museum. The curator, however, argued that the original donor no longer held any rights to the specimen nor did he have input into its representation. "At a meeting of the Museum Committee held, the Curator submitted a copy of the motion of Dr. Packard made at the August meeting of the College in reference to the withdrawal of a specimen, presented by him in January last and which motion had been referred by the College to the Museum Committee with power to act. 'After consideration and reference to the provided rules which govern the Committee, it was unanimously decided that the Committee had not the power to return a specimen deemed worthy of a place in the Museum to the donor after it has been once presented.",70

\footnotetext{
${ }^{69}$ Brinton, Personal Memoirs, 190.

${ }^{70}$ Oct. 3, 1866, John Packard, M.D. Mütter Museum.
} 
Anatomical museums such as the AMM had to contend with the social stigma of operating in a business, which invited people to gawk at human remains. As historian Michael Sappol wrote, anatomical museums "trucked in death and desire, emotions and appetites, corpses and body parts." However, all anatomical museums were not cut from the same cloth. There existed two types of museums during the nineteenth century, one "popular" the other "professional." Each catered to different clientele and associated themselves with different social and cultural merits.

Popular museums closely mirrored the outrageousness of dime museums and trafficked in lurid, even prurient, displays of body parts, genitalia, sexual diseases, and grotesquery that were opprobrious toward public sentiment. In 1871, the New York Times published an article lambasting popular museums for their "abnormal monstrosities" and "revolting specimens." Popular museums did not just exhibit the obscene, however, their success put the contradictions of middle-class morality on display as well. "Do you have any desire to study obstetrics?," the New York Times went on to ask. Anatomical museums were not just "transgressors of public morality," Sappol wrote, they were "flagrant transgressors." Yet, for all of the negative commentary hurled their way, these museums did not just exist during the nineteenth century, they thrived. ${ }^{71}$

Professional anatomical museums like Mütters and the AMM were just as concerned with their social reputation as they were with their collection and display of human remains. These museums were typically limited to medical professionals and other collectors. There existed a kind of "gentlemanly" quality to these museum goers who espoused a "connoisseur's appreciation" for the "artistry of preparation." Though

\footnotetext{
${ }^{71}$ Michael Sappol, "Morbid Curiosity: The Decline and Fall of the Popular Anatomical Museum." A Cabinet of Curiosities, 4 (Jan. 2004) (accessed August 18, 2015). www.commonplace.org.
} 
popular and professional, anatomical museums tended to display the same kinds of exhibits the differences came in terms of ideological disposition. Objects displayed in professional museums gave more emphasis on medical knowledge and the "conquest of reason" over the body. ${ }^{72}$ In an effort to quell any potential public criticisms the AMM went even further than its anatomical cousins by attributing its exhibits with a national importance. Brinton himself utilized a number of arguments to convince soldiers that their sacrifices served a national cause. While in the confines of the museum he could easily espouse military authority, however, when he met with resistance while collecting specimens on the front lines he was forced to use more creative methods.

I was informed of a remarkable injury of the lower extremity. The man had died with the limb on and had been carefully buried by his comrades. For some reason or other, that specimen was worth having, but his comrades had announced their determination to prevent the doctors from having it. However, I thought I would try what I can do, so I visited his mess mates, explained my object, dwelt upon the glory of a patriot having part of his body at least under special guard of his country, spoke of the desires of the Surgeon General to have that bone, with all such arguments I could adduce. My arguments were conclusive; the comrades of the dead soldier solemnly decided that I should have that bone for the good of the country. And in a body they marched out and dug up the body. I gravely extracted the bone and carried it off carefully; the spokesman of the party remarking gravely "that John would have given it to me himself, had he been able to express his opinion. ${ }^{73}$

As Brinton discovered, framing anatomical remains within the context of national importance resonated powerfully with soldiers whose very lives symbolized the Union cause. This message allowed the AMM to control the ownership of soldier's bodies even while placing them atop a national pedestal.

The advancement of scientific medicine during the war years drastically improved, thanks in large part to medical practitioners and Army Medical Museum, not to mention the soldiers' bodies. However, without public support the museum would not

\footnotetext{
${ }^{72}$ Michael Sappol, "Morbid Curiosity" (accessed August 18, 2015).

${ }^{73}$ Brinton, 191.
} 
have been able to collect and study human specimens. The public enthusiasm for viewing oddities and abnormalities fueled, and even authenticated, the AMM's ownership status of battlefield specimens. Changing attitudes of death and disability only heightened the importance of experimentation and the scientific study of human remains. It was these changes that ultimately laid the foundation for the golden age of American Medicine.

\section{Conclusion: Abnormal Bodies from the Colonial Era to the Post War Period}

The display of human bodies went through an evolutionary process from the colonial period to the Civil War. Bodies had been republicanized, democratized, legitimized, and sanctioned. Widespread public attraction to abnormal bodies pushed the boundaries of polite society, creating family friendly entertainment spaces that specialized in human oddity. By the end of the war, the display of anatomy became a legitimated, even necessary, endeavor. The Army Medical Museum's unrestricted right to soldier's bodies' drastically improved scientific knowledge. There was, however, another intriguing element underlying the strict relationship between the military and soldier, one that had much to do with the popularization of Barnumesque freak shows just a few decades earlier.

Permanently disabled soldiers underwent a transformative effect that was reminiscent of the abnormal bodies exhibited in freak shows across the north. Of course, apart from the most gruesome of injuries, soldiers were rarely recognized in the same context as "freaks or "monsters." However, permanently injured bodies did go through dramatic and life-altering changes, ones that not only altered their sense of self, but 
would forever impact their relationship with the world around them. In that moment of injury, soldiers suddenly and unexpectedly transformed from a healthy, normal body to an abnormal one. And it was the very essence of abnormality that allowed the AMM to claim ownership over individual pieces of soldiers. In effect, the federal government laid claim to differentness. In the words of Hammond himself, all specimens from the war "properly belong to the Army Medical Museum... [and that] no other disposition of these objects is permitted."74 The AMM was able to dictate anatomical specimens largely because contention issues tempered during the war years due to arguments of medical advancement and patriotic symbolism.

However, once the war was over, it became more difficult to tout nationalistic platitudes. Questions of ownership grew dramatically after the war, as the scientific community became obsessed with the study of racial and ethnic remains. Just as Barnum, Mütter, Hammond, and Brinton had done previously, scientists in the post war period found innovative ways to legitimize the scrutiny and exhibition of human remains. Bolstered by the scientific findings of Charles Darwin, social scientists heralded an entirely new wave of study based on highlighting so-called biological differences between Caucasians and other racial and ethnic groups. These findings were based on the notion that racial and ethnic specimens were abnormal when compared to normal (i.e. white) examples. Under the guise of scientific advancement, phrenology experts, accompanied by anatomical museums, laid claim to an assortment of skeletons domestically and internationally, even going so far as to sponsor the disinterment of

\footnotetext{
${ }^{74}$ Brinton to Thomas Markoe, March 4, 1863, Letterbooks of the Curators, RG 15, OHA, National Museum of Heath and Medicine. Emphasis in the original.
} 
native burial grounds. The social need to validate white superiority prompted decades of scientific racism and eventually laid the foundations for the ensuing eugenics movement. 
CONCLUSION: Government and Disabled Veterans in the Postwar Years

The impact of maimed bodies did not end with Lee's surrender at Appomattox. Rather, disability continued to play an important role in shaping the postwar period. As soldiers transitioned to veterans their story became part of the national narrative. They marched to cheering crowds in grand reviews across northern cities while the empty sleeves among them epitomized the Union's sacrifice. They became recognizable heroes in poems, essays, and autobiographies for a public eager to read romanticized versions of the war. Politically, veterans waved the bloody shirt in local, state, and national politics. As time passed and old war injuries inched toward permanent limitations, the meaning of veterans' wounds shifted in the north. Narratives that once hailed the heroism of wounded veterans soon found competition with stories that portrayed pitiable sufferers. The political discourse surrounding aging veterans changed as a younger generation of politicians interpreted wounds as fiscal burdens on the federal treasury. The debate only worsened as the qualification requirements for pensions broadened in the late nineteenthcentury. By 1893 there were over 876,068 veterans who received some kind of government assistance, at a total expenditure of $\$ 146,737,350$ annually. ${ }^{1}$ These debates did more than illustrate generational controversy, however. Their public arguments exemplified the shifting relationship between government and wounded veterans, an issue wrought by the Civil War.

A long history exists of government assistance for disabled soldiers. Permanently injured veterans received monetary assistance as far back as the colonial period, the amount of which was directly proportional to their ability to support themselves. These

\footnotetext{
${ }^{1}$ James Marten, Sing Not War: The Lives of Union and Confederate Veterans in Gilded Age America (Chapel Hill: The University of North Carolina Press, 2011), 17.
} 
programs continued after the American Revolution, though with some significant differences. Military rank determined fiscal benefits rather than injury or need, creating an unequal and disorganized distribution of funds. ${ }^{2}$ Difficulty in keeping the treasury full only exacerbated the problem. What the early republic lacked in funds, however, they made up for with an abundance of land. When federal coffers were low, the government gave away land to veterans who qualified for assistance. While disability itself did not necessarily preclude veterans from receiving land, their bodily limitations ensured that they could not turn these pensions into workable farms. ${ }^{3}$

When federal and state governments were able to provide funds, meager though they were, the social stigmas attached to those monies were enough to dissuade many veterans from accepting assistance. Antebellum views of independence and manhood made no distinction between government assistance and welfare. The collection of alms was synonymous with "putting the veteran on the dole," a rather undignified way of earning an income. ${ }^{4}$ So as not to be a public burden, disabled or elderly soldiers who needed extra care were expected to rely on family members. Charges of beggary and indolence were levied against those whose circumstances forced them to claim government funds. Herman Melville, himself, disparaged veterans who asked for assistance. In his Israel Potter: Fifty Years of Exile (1855), Melville denoted the social aversion toward drawing pensions. This idea formed the basis of Israel's refusal to seek help despite his hardships, "while some of the genuine heroes, too brave to beg, too cut up to work, too poor to live, laid down quietly in the corners and died...And here it may

\footnotetext{
2 David Gerber, "Creating Group Identity: Disabled Veterans and the American Government" Organization of American History Magazine, 23, (July 2009): 24.

${ }^{3}$ Emily J. Teipe, America's First Veterans and the Revolutionary War Pensions (Lewiston: The Edwin Mellon Press, 2002).

${ }^{4}$ Gerber, 24.
} 
be noted, as a fact nationally characteristic, that however desperately reduced at times, even to the sewers, Israel, the American, never sunk below the mud to actual beggary." To the men and women living in the antebellum period, Melville's message was clear: true veterans, no matter the circumstances, did not ask for assistance. ${ }^{5}$

The characteristic weakness associated with pensions fundamentally changed during the Civil War. Over two million northerners left their loved ones to answer Lincoln's national call. In their service to the nation, hundreds of thousands left a piece of themselves on the field before returning home. The overwhelming number of disabled men coming out of the war, along with the imbued symbolism of the empty sleeve, ensured that the northern public would support, or rather, demand, a radical shift in the scrutiny of pensions. The public discourse that surrounded disabled veterans moved from a need-based system to one centered on "rights." Far from viewing ex-soldiers as public charges, governments were now expected to provide funds for those who sacrificed for the Union. Lincoln himself attested to this idea in the closing remarks in his Second Inaugural Address: "With malice toward none, with charity for all...let us strive on to finish the work we are in, to bind up the nation's wounds, to care for him who shall have borne the battle and for his widow and his orphan, to do all which may achieve and cherish a just and lasting peace among ourselves and with all nations." ${ }^{6}$ Even before the conclusion of the war, state and federal governments passed legislation providing for permanently disabled soldiers. In 1863 the Confederacy established the Veterans

\footnotetext{
${ }^{5}$ Ann Fabian, The Unvarnished Truth: Personal Narratives in the Nineteenth-Century America (Berkley: University of California Press, 2000), 10.

${ }^{6}$ Abraham Lincoln, Second Inaugural Address, March 4, 1865.
} 
Soldiers Home as a space to care for injured men. ${ }^{7}$ The federal Congress created the National Asylum for Disabled Volunteer Soldiers by the spring of 1865 . The organization continued to grow in the decades after the war, and provided care to over 100,000 veterans, widows, and orphans. ${ }^{8}$ These establishments sought to remove the image of charitable "asylums" and instead present restful sanctuaries that provided support and comfort to infirm veterans. ${ }^{9}$ These homes were quite luxurious by Victorian standards often including libraries, billiard halls, and even theaters.

Despite the initial gratitude shown by the northern public, Union veterans, especially disabled ones, were also endemic of the growing social issues that plagued the nation. Those who found success in the postwar period were venerated as symbols of perseverance and strength while those who did not were subject to public opprobrium. Disability exemplified the failure of men, along with a lack of ambition, despite their bloody shirt. ${ }^{10}$ Cities across the north linked maimed bodies with indolence and failure in an effort to remove unwanted "vagrants" from their streets. In the 1870s San Francisco and Chicago passed "ugly laws" making it illegal for unsuccessful men with deformities to appear publically. The Chicago Municipal Code Section \#36034 stated:

\begin{abstract}
No person who is diseased, maimed, mutilated, or in any way deformed so as to be an unsightly or disgusting object or improper person to be allowed in or on the public ways or other public places in this city, or shall therein or thereon expose himself to public view, under a penalty of not less than one dollar nor more than fifty dollars for each offense. ${ }^{11}$
\end{abstract}

\footnotetext{
${ }^{7}$ Confederate veterans did not qualify for benefits from the federal government. The responsibility of their care fell upon southern state governments.

${ }^{8}$ Like anatomical museums, Soldier's Homes became popular tourist attractions for citizens who wished to picnic and engage with living relics. Marten, 17.

${ }^{9}$ Rusty Williams, My Old Confederate Home: A Respectable Place for Civil War Veterans (Lexington: University of Kentucky Press, 2010).

${ }^{10}$ Scott A. Sandage, Born Losers: A History of Failure in America (Cambridge: Harvard University Press, 2005).

${ }^{11}$ Most cities did not repeal the Ugly Laws until the 1970s.
} 
By the 1890s sections of Pennsylvania, Ohio, Illinois, and Nebraska followed suit. ${ }^{12}$

The boom and bust cycles of the Gilded Age prompted many to question the expansion of veterans' benefits. Not only did the federal treasury provide funds for individuals and Soldier's Homes, but they also allocated monies toward the purchase of prosthetic limbs for military amputees. ${ }^{13}$ The topic of veteran's benefits came up again in 1887 when Congress, pressured by the powerful Grand Army of the Republic (GAR), passed a bill providing pensions for those who developed disabilities after the war. Amid the bill's financial and social tumult, however, Grover Cleveland vetoed the legislation. His rejection of the bill paved the road for a Republican victory in the next election and in 1890 Benjamin Harrison signed the Dependency and Disabilities Pension Act into law. The act effectively turned veteran benefits into an "old age subsidy."14 Three years later, pension recipients accounted for 43 percent of the federal budget, to the tune of 160 million dollars annually. ${ }^{15}$

The relationship between wounded soldiers and the government continued to expand in the twentieth-century. By the end of the First World War a vast bureaucratic agency developed to oversee benefit programs. Though American soldiers were only in Europe for eighteen months they experienced the dangers of mechanized weapons and large-scale artillery, as well as the debilitating effects of phosgene and mustard gas. In addition, intense nervous breakdowns and shell shock attested to the validity of combat induced psychological injury. The social view of these mental issues mirrored previous

\footnotetext{
${ }^{12}$ Susan Schweik, The Ugly Laws: Disability in Public (New York: New York University Press, 2010)

${ }^{13}$ Military subsidies created a broad interest in developing the "mechanical art". Between 1846 and 1873 , 167 patents were awarded for innovative prosthetics. Stephen Mihm, "'A Limb Which Shall Be Presentable in Polite Society': Prosthetic Technology in the Nineteenth Century," in Artificial Parts, Practical Lives: Modern Histories of Prosthetics, ed. Katherine Ott, David Serlin, and Stephen Mihm, (New York: New York University Press, 2002), 283.

${ }^{14}$ Gerber, 24.

${ }^{15}$ Marten, 219.
} 
stigmas, attributing neurological impairment with weakness. In all, over 200,000 Americans suffered some kind of serious injury causing long-term hardship in their lives. By 1930 the federal government recognized the need for an official department charged with managing military benefits. The establishment of the Veterans Administration (VA) marked an important moment in the government's commitment toward its military volunteers, one that developed out of the hundreds of thousands of wounded bodies coming before it. ${ }^{16}$ When the United States entered into another world war, the military sought to decrease the psychological impact of combat by instituting a series of clinical exams aimed at early identification of potential weakness. Despite their efforts, combat related psychological issues continued to plague American soldiers, bolstering the number to disabled veterans to nearly $675,000 .{ }^{17}$ While military psychiatrists conducted numerous exams during the war years they neglected to study issues that arose after soldiers returned home, a mistake that revealed itself during Vietnam. It was not until 1980 when Post Traumatic Stress Disorder (PTSD) became an officially recognized disability outlined by the American Psychiatric Association. Though controversial when first introduced, PTSD recognized trauma as the etiologic event of psychological disorders rather than personal character flaws. Today, PTSD accounts for some of the highest disability numbers for veterans. According to the United States Department of Veterans Affairs, approximately 12 percent of veterans from the Gulf War suffer from PTSD, a number that has grown during the more recent Operations Iraqi Freedom and Enduring Freedom, which places PTSD among veterans as high as 20 percent. $^{18}$

\footnotetext{
${ }^{16}$ In 1989 the Department of Veterans Affairs was elevated to a cabinet position.

${ }^{17}$ Gerber, 24-25.

${ }^{18}$ PTSD: National Center for PTSD, (ND) United States Department of Veteran Affairs Accessed Friday September 11, 2015, from http://www.ptsd.va.gov/public/PTSD-overview/basics/how-common-is-ptsd.asp
} 
The role of disability has had an indelible impact on the development of the nation. Not only did wounded bodies provide a means for military personnel and citizens to understand the devastating impact of the war, they also paved the road for a number of postwar industries. Over the past 150 years this came to incorporate assistive technologies in the form of prosthetics, long-term medical care, specialized hospitals, as well as physical and psychological rehabilitation services. Their injuries reinforced the barometer for normalcy and American identity, while implicitly infusing our language with ideas of strength and virility. "Standing up for oneself" and "turning a deaf ear" became clichés at the expense of those who were unable to stand or hear. Wounded veterans helped enrich the understanding of rights-based citizenship that Americans continue to enjoy today, their sacrifices symbolizing the government's responsibility toward its citizens. The study of wounded bodies during the Civil War is just one way to investigate the ubiquitous nature of disability in our history. 


\section{BIBLIOGRAPHY:}

\section{Manuscript Sources:}

Gilder Lehrman Institute, New York, NY:

James R. Kelly Letters

Historical Society of Philadelphia, Philadelphia, Pa:

Mrs Irvin H. McKesson Collection. Call No. 1542

Grier, Helen. Personal Diary. No. Am .6090.

Samuel Kapp Family Papers. Call No. 3066

Merklee, Amanda. Diaries and Record Books. Call No. Am .13751.

Reports of the General Hospitals United States Army. Call No. Wq.963

National Archives, Washington, DC:

Record Group 112, "Circulars of the Surgeon General's Office"

Record Group 94, "George A. Otis Collection"

National Library of Medicine, Bethesda, MD:

Record Group 13, OHA

Sterns, Amanda. "Armory Square Hospital Nursing." Diary.

Louis J. Jordan. Digitized Collection

George Tiemann \& Company. Collection of Advertising Brochures

National Museum of Health and Medicine, Silver Spring, MD:

Lamb, Daniel. A History of the United States Army Medical Museum, 1862-

1917. Unpublished.

Mütter Museum, Philadelphia, Pa:

College of Physicians of Philadelphia Committee,1864-1941, Reports

The Hyrkl collection

Southern Historical Collection, Chapel Hill, NC:

Hentz Family Papers, Folder 23.

Joseph Kauffman. Diary. Southern Historical Collection.

McGraw Family Papers

U.S. Army Heritage and Education Center, Carlisle, Pa:

Cyrus Bacon Papers. Civil War Times Illustrated Collection

Helen L. Gilson Papers. Civil War Times Illustrated Collection

E.N. Harris Papers. Civil War Times Illustrated Collection

Jacob S. Kiester Papers Civil War Times Illustrated Collection 


\section{Primary Sources:}

Alcott, Louisa May. Hospital Sketches. Boston: James Redpath Publishers, 1863.

Alcott, Louisa May. Journals of Louisa May Alcott, ed. Joel Myerson, Daniel Shealy, and Madeleine B. Stern. Boston: Little, Brown, 1989.

Alleman, Matilda Tillie Pierce At Gettysburg, or What a Girl Saw and Heard of the Battle, A True Narrative. New York: W Lake Borland, 1889.

American Publishers' Circular and Literary Gazette, September 1, 1863, 346.

Ames, John W. Papers, 1861-1863. U.S. Army Heritage and Education Center.

Ames, Mary Clemmer. Ten Years in Washington: Life and Sciences in the National Capital. Hartford: A.D. Worthington \& Company, 1873.

Bagger, Louis. "The Army Medical Museum in Washington" Appleton's Journal 9 (March 1, 1873): 294-297.

Bailey, Judith A. and Robert Cottom, ed. After Chancellorsville Letters from the Heart: The Civil War Letters of Private Walter G. Dunn \& Emma Randolph. Baltimore: Maryland Historical Society, c1998.

Barnum, P.T. The Life of P.T. Barnum, Written by Himself. 1855 reprint, Urbana: University of Illinois Press, 2000.

Baynard, Edward. Health, A Poem. $7^{\text {th }}$, ed. London 1742.

Bellard, Alfred. Gone for a Soldier. Ed. David Herbert Donald. Toronto: Little Brown and Company, 1975.

Bennitt, John. I Hope to do my Country Service: The Civil War Letters of John Bennitt, M.D., Surgeon, $19^{\text {th }}$ Michigan Infantry. ed. Robert Beasecker. Detroit: Wayne State University Press, 2005.

Behling, Laura. Gross Anatomies: Fictions of the Physical in American Literature. Selinsgrove: Susquehanna University Press, 2008.

Boardman, Andrew. "Essays on the Means of Improving Medical Education and Elevating Medical Character," in Medical America in the Nineteenth Century: Readings from Literature ed. Gert H. Brieger. Johns Hopkins Press: Baltimore.

Brown, Edmund. The Twenty-Seventh Indiana Volunteer Infantry in the War of the Rebellion 1861 to 1865. Gaithsburg : Butternut Press, 1899. 
Brinton, John H. Personal Memoirs of John H. Brinton: Civil War Surgeon, 1861-1865. Ed. John S Haller Jr., Carbondale: Southern Illinois University Press, 1996.

Brockett, Linus Pierpont. Camp Battlefield and Hospital, Or, Lights and Shadows of the Great Rebellion. New York: Union Publishing House, 1866(?).

Brumgardt, John, ed. Civil War Nurse: The Diary and Letters of Hannah Ropes. Knoxville: The University of Tennessee Press, 1980.

Calhoun, John C. "Mr. Calhoun to Mr. Pakenham," in Richard K. Cralle, ed., The Works of John C. Calhoun (New York: D. Appleton, 1888), 5:337.

Corson. John W. M.D., Loiterings in Europe: Sketches of Travel in France, Belgium, Switzerland, Italy, Australia, Prussia, Great Britain, and Ireland New York: Harper and Brothers Publisher, 1848. Located at National Library of Medicine.

Cummings, Chas. L. The Great War Relic: A Poetical Description of the $6^{\text {th }}$ Army Corps Campaign During the Year 1863. Harrisburg, Meyers Print, 1848.

Craig, Samuel A. Memoirs of the Civil War and Reconstruction. Civil War Times Illustrated Collection.

Davis, Nathan S. History of the American Medical Association from its Organization up to January, 1855 Philadelphia, 1855.

De Forest, John W. A Volunteer's Adventures: A Union Captain's Record of the Civil War. New Haven: Yale University Press, 1946.

Dickenson, Emily. Emily Dickenson Letters to Dr. and Mrs. Josiah Gilbert Holland. Cambridge: Harvard University Press, 1951.

Ellis, Thomas. Leaves from the Diary of an Army Surgeon; or, Incidents of Field, Camp, and Hospital Life. New York: Bradburn, 1863.

Emmell, Heyward. The Civil War Journal of Private Heyward Emmell: Ambulance and Infantry Corps: A Very Disagreeable War. ed. Jim Malcolm. Madison: Fairleigh Dickinson University Press, 2011.

Fisher, Mary C. "A Week on Gettysburg Field," Grand Army Scout and Soldiers Mail, 1883, vol. II, no. 12, 2-6.

Fiske, Samuel. Mr. Dunn Brown's Experience in the Army: The Civil War Letters of Samuel Fiske. Ed. Stephen Sears. New York: Fordham University Press, 1998.

Gray, John H. The Policy of Chartering Colleges of Medicine. New York, 1833. 
Greiner, James M. and Janet L. Coryell ed. A Surgeon's Civil War: The Letters and Diary of Daniel M. Holt, M.D. Ohio: Kent State University Press, 1994.

Gross, Samuel D. Autobiography of Samuel D. Gross: With Sketches of his Contemporaries. Vol. II. Philadelphia: George Barrie Publishing, 1873.

Hammond, William Alexander. Military Medical and Surgical Essays. "Amputations," Philadelphia: J.B. Lippincott \& Co., 1864.

Holmes, Oliver Wendell. "Currents and Counter-Currents in Medical Science," (1860), in collected papers of the same title. Cambridge, Mass. 1861. 580.

. "The Human Wheel." Atlantic Monthly. May, 1863: 567-

Hoke, Jacob. Historical Reminiscences of the War, or, Incidents Which Transpired In and About Chambersburg During the War of the Rebellion (Chambersburg, PA: M.A. Foltz, Printer and Publisher, 1884), 172.

Hooker, W. "The Present Mental Attitude and Tendencies of the Medical Profession," New Englander. X (1852).

Johnson, Charles F. The Civil War Letters of Colonel Charles F. Johnson, Invalid Corps. Ed. Fred Pelka. Amherst: University of Massachusetts Press, c.2004.

Moore, Jane Boswell. The U.S.C.C. Maryland Report, 104-107.

Newcomb, Mary A. Four Years of Personal Reminiscences of the War. Chicago: H.S. Mills, 1893.

"The Origin, Organization, and the Working of the Women's Central Association of Relief," Documents of the United States Sanitary Commission. 2 vols. New York, 1966.

Osler, William. Aequanimitas. Philadelphia: P. Blakiston’s Son \& Co., 1932.

Percy, Mary Christian. Augustus Cowan Papers, Illinois State Historical Library, Springfield.

Rush, Benjamin. The Selected Writings of Benjamin Rush. Ed. Dagobert D. Runes. New York: Philosophical Library, 1947.

The Sights and Wonders in New York: Including a description of the mysteries, miracles, marvels, phenomena, curiosities, and nondescripts, contained in that 
great congress of wonders, Barnum's Museum. New York: J.S. Redfield, 1849. The Library Company of Philadelphia.

Souder, Emily. Leaves from the battlefield of Gettysburg: A Series of Letters from a Field Hospital. Philadelphia: Caxton Press, 1864.

Smith, William. History of the province of New York. (London, 1757).

Thomson, Samuel. New Guide to Health; or Botanic Family Physician, 1822. . Thomsonian Recorder 1 December 15, 1832.

Van Evrie, John H. White Supremacy and Negro Subordination, or Negroes A Subordinate Race (New York: Van Evrie, Horton, \& Co., 1868).

Wainwright, Charles S. A Diary of Battle: The Personal Journals of Charles S. Wainwright, 1861-1865. Ed. Allan Nevins. Cambridge: DaCapo Press, 1998.

Whitman, Walt. Leaves of Grass. New York: Oxford University Press, 2005. . , "Hospital Visits" The Complete Writings of Walt Whitman. . Memoranda During the War [\&] Death of Abraham Lincoln. ed. Roy P. Basler. Bloomington: Indiana University Press, 1962. 1971. . Specimen Days. Ed. Alfred Kazin. Boston: David R. Godine Publishing, . The Wound Dresser: A Series of Letters Written from the Hospitals, 1892.

Wormeley, Katharine. Other Side of War with the Army of the Potomac: Letters from the Headquarters of the United States Sanitary Commission during the Peninsular Campaign in Virginia in 1862. Boston: Ticknor, 1889.

Wright, Isaac. Family Medicine, or System of Domestic Practice. Henderson, Johnson \& Co: Madisonville Tennessee, 1833.

\section{Books:}

Adams, Bluford. - E. Pluribus Barnum: The Great Showman and the Making of U.S. Popular Culture. Minneapolis: University of Minnesota Press, 1997.

Adams, George Worthington. Doctors in Blue: The Medical History of the Union Army in the Civil War. New York: Henry Schuman, 1952.

Allen, Gay Wilson. Solitary Singer. New York: Macmillan Company, 1955. 
Aptowicz, Cristin O'Keefe. Dr. Mütter's Marvels: A True Tale of Intrigue and Innovation at the Dawn of Modern Medicine. Gotham Books: New York City, 2014.

Ashby, Leroy. With Amusement For All: A History of American Popular Culture Since 1830. Lexington: University Press of Kentucky, 2006.

Barney, William. The Making of a Confederate: Walter Lenoir's Civil War. New York: Oxford University Press, 2008

Benjamin, Marcus. Ed. Washington During War Time. Washington D.C. The National Tribune Co, 1902.

Berns, Gregory. Satisfaction: The Science of Finding True Fulfillment. New York: Henry Holt, 2005.

Berry, Stephen. Weirding the War: Stories from the Civil War's Ragged Edges. Athens: The University of Georgia Press, 2011.

Bogdan, Robert. Freak Show: Presenting Human Oddities for Amusement and Profit. Chicago: University of Chicago Press, 1988.

Bollet, Alfred. Civil War Medicine: Challenges and Triumphs. Tucson: Galen Press, 2002.

Bourke, Joanna. Dismembering the Male: Men's Bodies, Britain and the Great War. Chicago: University of Chicago Press, 1996.

Bronstein, Jamie. Caught in Machinery: Workplace Accidents and Injured Workers in Nineteenth Century Britain. Palo Alto: Stanford University Press, 2007.

Brooks, Stewart. Civil War Medicine. Springfield: Charles C. Thomas Publisher, 1966.

Brown, Julie. Health and Medicine on Display: International Expositions in the United States, 1876-1904. Cambridge: MIT Press, 2009.

Burke, Peter. What is Cultural History? Cambridge: Polity, 2004, 2008.

Carlino, Andrea. Books of the Body: Anatomical Ritual and Renaissance Learning. Chicago: University of Chicago Press, 1999.

Carter, Robert Goldwaithe. Four Brothers in Blue. Austin, 1978. 
Clarke, Frances. War Stories: Suffering and Sacrifice in the Civil War North. Chicago: University of Chicago Press, 2011.

Coco, Gregory. Strange and Blighted Land: Gettysburg, the Aftermath of a Battle. Gettysburg: Thomas Publications, 1998.

Cohen, Deborah. The War Come Home: Disabled Veterans in Great Britain and Germany (The university of California Press, 2001

Cohen, Patricia. The Murder of Helen Jewett: The life and Death of a Prostitute in Nineteenth-Century New York. New York: Random House Publishing, 1998.

Cook, James. The Arts of Deception: Playing with Fraud in the Age of Barnum. Cambridge: Harvard University Press, 2001.

Coventry, C.B. "History of Medical Legislation in the State of New York," N.Y. Journal of Medicine, IV (1845).

Cunningham, H. H. Doctors in Gray: The Confederate Medical Service. Baton Rouge: Louisiana State University Press, 1960.

. Edmund Burke Haywood and Raleigh's Confederate Hospitals.

. Field Medical Services at the Battles of Manassas. Athens: University of Georgia Press, 1968.

Davis, Leonard J. Enforcing Normalcy: Disability, Deafness, and the Body. New York: Verso, 1995.

Denney, Robert. Civil War Medicine: Care and Comfort of the Wounded. New York: Sterling Publishing, 1995

Dennett, Andrea Stulman. Weird and Wonderful: The Dime Museum in America. New York: New York University Press, 1997.

Devine, Shauna. Learning from the Wounded: The Civil War and the Rise of American Medical Science. Chapel Hill: University of North Carolina Press, 2014.

Downs, Jim. Sick from Freedom: African-American Illness and Suffering during the Civil War and Reconstruction. Oxford: Oxford University Press, 2012.

Ehler, C.A. "Hospital Scenes from Gettysburg." Historical Society of Pennsylvania. Society papers.

Erkkila, Betsy and Jay Grossman. Breaking Bounds: Whitman and American Cultural Studies. Oxford: Oxford University Press, 1996. 
Fabian, Ann The Skull Collectors: Race, Science, and America's Unburied Dead. University of Chicago Press: Chicago, 2010.

. Unvarnished Truth: Personal Narratives in Nineteenth-Century America. Berkley: University of California Press, 2000.

Fahs, Alice. The Imagined Civil War: Popular Literature of the North and South. 1861-1865. Chapel Hill: University of North Carolina, 2001.

Faust, Drew Gilpen, This Republic of Suffering: Death and the American Civil War. New York: Vintage Books, 2008.

Freemon, Frank. Gangrene and Glory: Medical Care during the American Civil War. Madison: Fairleigh Dickinson University Press, 1998.

Medicine. . Microbes and Minie Balls: An Annotated Bibliography of Civil War Rutherford: Fairleigh Dickinson University Press, 1993.

Foreman, Steven. A Guide to Civil War Washington. Washington D.C. Elliot \& Clark Publishing, 1995.

Foucault, Michel, The History of Sexuality, Volume I: An Introduction. New York: Vintage, 1990.

Gallman, Matthew, J. Mastering Wartime: A Social History of Philadelphia During the Civil War. Philadelphia: University of Pennsylvania Press, 2000.

Garland-Thomson, Rosemarie. Ed. Freakery: Cultural Spectacles of the Extraordinary Body. New York: New York University Press, 1996.

_. Staring: How We Look. New York: Oxford University Press, 2009.

Giesberg, Judith Ann. Civil War Sisterhood: The U.S. Sanitary Commission and Women's Politics in Transition. Boston, Northeastern University Press, 2000.

Ginzberg, Lori. Women in Antebellum Reform. Wheeling: Harlan Davidson, Inc, 2000.

Glatthaar, Joseph. General Lee's Army: From Victory to Collapse. New York: Free Press, 2008.

Gordon, Beverly. Bazaars and Fair Ladies: The History of the American Fundraising Fair. Knoxville: University of Tennessee Press, 1998. 
Gorn Elliot J. and Warren Goldstein, Warren. A Brief History of American Sports. University of Illinois Press, 2004.

Grimsley, Mark. Hard Hand of War: Union Military Policy Toward Southern Civilians, 1861-1865. Cambridge: Cambridge University Press, 1995.

Halttunen, Karen. Murder Most Foul: The Killer and the American Gothic Imagination. Cambridge: Harvard University Press, 1998.

Hammerstrom, David. Fall of the Big Top: The Vanishing American Circus. Jefferson: McFarland and Company, 2008.

Haskell, Frank A. The Battle of Gettysburg ed. Bruce Catton. Boston: Houghton Mifflin, 1958.

Herndl, Diane Price. Invalid Women: Figuring Feminine Illness in American Fiction and Culture, 1840-1940. Chapel Hill: University of North Carolina Press, 1993.

Hess, Earl. Union Soldier in Battle: Enduring the Ordeal of Combat. Lawrence: University of Kansas Press, 1997.

Hofstader, Richard. Social Darwinism in American Thought, 1860-1915. Philadelphia: University of Pennsylvania Press, 1944

Humpherys, Margaret. Intensely Human: The Health of the Black Soldier in the American Civil War. Baltimore: John's Hopkins University Press, 2008.

. Marrow of Tragedy: The Health Crisis of the American Civil War. Baltimore: Johns Hopkins University, 2013.

Kelly, Howard A. and Walter L. Burrage. American Medical Biographies. Baltimore: The Norman, Remington Company 1920.

Kelly, Patrick. Creating a National Home: Building the Veterans' Welfare State, 18601900. Cambridge: Harvard University Press, 1997.

King, Lester. Transformation in American Medicine: From Benjamin Rush to William Osler. Baltimore: Johns Hopkins University Press, 1991.

Kimmel, Stanley. Mr. Lincoln's Washington. New York: Coward-McCann, 1957.

Larkin, Jack. The Reshaping of Early Life: 1790-1840. Harper Perennial, 1989.

Leech, Margaret. Reveille in Washington, 1860-1865. New York: Harper and Brothers, 1941. 
Lewis, Robert M. ed. From Traveling Show to Vaudeville: Theatrical Spectacle in America, 1830-1910. Baltimore: John's Hopkins University Press, 2003.

Liverpool, Thomas L. Numbers and Losses in the Civil War in America 1861-1865 Civil War Centennial Series, Bloomington: Indiana University Press, 1957.

Logue, Larry and Michael Barton. Civil War Veteran: A Historical Reader. New York: New York University Press, 2007.

Logue, Larry, Peter Blanck. Race, Ethnicity, and Disability: Veterans and Benefits in Post-Civil War America. New York: Cambridge University Press, 2010.

Long, Lisa. Rehabilitating Bodies: Health, History, and the American Civil War. Philadelphia, University of Pennsylvania Press, 2004.

Lord, Francis. They Fought for the Union. New York: Bonanza Books, 1960.

Longmore, Paul, Lauri Umansky. Ed. The New Disability History: American Perspectives. New York: New York University Press, 2001.

Marten, James. Sing Not War: The Lives of Union \& Confederate Veterans in the Gilded Age America. Chapel Hill: University of North Carolina Press, 2011.

McConachie, Bruce A. Melodramatic Formations: American Theater and Society, 1820-1870. Iowa City: University of Iowa Press, 1992.

McPherson, James. Battle Cry for Freedom. New York, Oxford University Press, 1988.

Medical and Surgical History of the Civil War. Wilmington: Broadfoot Publishing Company, 1991. VI, 897.

Miller, Brian. Empty Sleeves: Amputation in the Civil War South. Athens: University of Georgia Press, 2015

John Bell Hood and the Fight for Civil War Memory. Knoxville:

University of Tennessee Press, 2010

Mitchell, David. The Body and Physical Difference: Discourses of Disability (The Body, In Theory: Histories in Cultural Materialism. Ann Arbor: University of Michigan Press, 1997.

Morris, David. The Culture of Pain. (Berkley: University of California Press, 1998).

Munden, Kenneth, and Henry Beers, A Guide to Federal Archives Relating to the Civil 
War. National Archives, National Archives and Records Service, General Services Administration, 1962.

Nelson, Megan Kate. Ruin Nation: Destruction and the Civil War South. Athens: University of Georgia Press, 2012.

Ott, Katherine and David Serlin. Ed. Artificial Parts, Practical Lives: Modern Histories of Prosthetics. New York: New York University Press, 2002.

Quentin, William. Lincoln's Fifth Wheel: The Political History of the United States Sanitary Commission. New York: Longmans, Green, 1956.

Reimer, Terry. One Vast Hospital: The Civil War Hospital Sites in Frederick, Maryland, after Antietam: With Detailed Hospital Patient List. Frederick: National Museum of Civil War Medicine, 2001.

Reiss, Benjamin. The Showman and the Slave: Race, Death, and Memory in Barnum's America. Cambridge: Harvard University Press, 2010.

Reznick, Jeffery. Healing the Nation: Soldiers and the Culture of Caregiving in Britain During the Great War. Manchester: Manchester University Press, 2005.

Rockman, Seth. Welfare Reform in the Early Republic: A Brief History with Documents. Bedford/St. Martins, 2002.

Russett, Cynthia Eagle. Sexual Science: The Victorian Construction of Womanhood. Cambridge, Massachusetts: Harvard University Press, 1989.

Rutkow, Ira. Bleeding Blue and Gray: Civil War Surgery and the Evolutions of American Medicine. New York: Random House, 2005.

Sandage, Scott. Born Losers: A History of Failure in America. Cambridge: Harvard University Press, 2005.

Sappol, Michael. A Traffic of Dead Bodies: Anatomy and Embodied Social Identity in the Nineteenth-Century America. Princeton: Princeton University Press, 2002.

Saxon, A.H. P.T. Barnum: The Legend and the Man. New York: Columbia University Press, 1989.

Schildt, John. Antietam Hospitals. Antietam: Antietam Publications, 1996.

Schroeder-Lein, Glenna. Confederate Hospitals on the Move: Samuel H. Stout and the Army of Tennessee. Columbia: University of South Carolina, 1994.

Schultz, Jane. The Birthplace of Souls: The Civil War Nursing Diary of Harriet Eaton. New York: Oxford University Press, 2010. 
Schweik, Susan. The Ugly Laws: Disability in Public. New York: New York University Press, 2009.

Sellers, Charles Coleman. Mr. Peale's Museum: Charles Willson Peale and the First Popular Museum of Natural Science and Art. New York: W.W. Norton and Company, 1980.

Sentilles, Renée. Performing Menken: Adah Isaacs Menken and the Birth of American Celebrity. Cambridge: Cambridge University Press, 2003.

Sontag, Susan. On Photography. New York: Picador, 1977.

. Regarding the Pain of Others. New York: Picador, 2003.

Shryock, Richard. Medicine in America Historical Essays. Baltimore: Johns Hopkins University Press, 1966.

. Medical Licensing in America, 1650-1965. Baltimore: Johns Hopkins University Press, 1967.

. Medicine and Society in America, 1660-1860. New York: New York University Press, 1960.

Snyder, Sharon. Ed. Disability Studies: Enabling the Humanities. New York: The Modern Language Association of America, 2002.

Starr, Paul. The Social Transformation of American Medicine: The Rise of a Sovereign Profession and the Making of a Vast Industry. New York: Basic Books, Inc., 1982.

Stevens, Rosemary. American Medicine and the Public Interest. New Haven: Yale University Press, 1971.

Thayer, Stuart. Traveling Showman: The American Circus before the Civil War. Detroit: Astley and Ricketts, 1997.

Thomson, Rosemary Garland, ed. Freakery: Cultural Spectacles of the Extraordinary Body. New York: New York University Press, 1996.

Trachtenberg, Alan. Reading American Photographs: Images as History Matthew Brady to Walker Evans. New York: Noonday Press, 1989. . The Incorporation of America: Culture and Society in the Gilded Age. New York: Hill\& Wang, 1982. 
Teipe, Emily J. America's First Veterans and the Revolutionary War Pensions. Lewiston: The Edwin Mellon Press, 2002.

Washington, Harriet A. Medical Apartheid: The Dark History of Medical Experimentation on Black Americans from Colonial Times to the Present. Knopf Doubleday Publishing, 2007.

Williams, Rusty. My Old Confederate Home: A Respectable Place for Civil War Veterans. Lexington: University Press of Kentucky. 2010.

\section{Articles:}

Alpers, Svetlana. "The Museum as a Way of Seeing." In Exhibiting Cultures: The Poetics of Museum Display, ed. Steven D. Lavine. Washington D.C.:

Smithsonian Institution, 1991. Pp 25-32.

Baynton, Douglas. "Defectives in the Land: Disability and American Immigration Policy, 1882-1924." Journal of American Ethnic History, Vol. 24, no. 3 (Spring 2005): 31-44.

. "Disability in History." Disabilities Studies Quarterly. (Summer 2008) Vol. 28. No 3 .

Baron-Cohen, Simon. "Mindblindness: An Essay on Autism and "Theory of Mind," Learning, Development, and Conceptual Change. Cambridge: MIT Press, 1995.

Burch, Susan. "(Extraordinary) Bodies of Knowledge: Recent Scholarship in American Disability History." Organization of American Historians Magazine of History, Vol. 23, no. 3 (July 2009): 29-34.

Clarke, Frances. "“"Honorable Scars:” Northern Amputees and the Memory of Civil War Injuries," in Union Soldiers and the Northern Home Front: Wartime Experiences, Postwar Adjustments. ed. Paul Cimbala and Randall M. Miller. New York: Fordham University Press, 2002.

Cimbala, Paul. "Soldiering on the Home Front: The Veteran Reserve Corps and the Northern People." In Union Soldiers and the Northern Home Front, ed. Paul Cimbala and Randall Miller. New York: Fordham University, 2002. Pp 182-218.

Davis, Leonard J. "Bodies of Difference: Politics, Disability, and Representation," in Disability Studies: Enabling the Humanities ed. Sharon L. Snyder, Brenda Jo Brueggmann, and Rosemarie Garland-Thomson. New York: Modern Language Association of America, 2002. 
Etter, William. "Cripple, Soldier, Crippled Soldier." Prose Studies 27, no. 1\&2, (2005): 80-92.

Fairchild, Amy. "Historicizing the Notion of Disability," Journal of American Ethnic History Vol. 24, No. 3 (Spring 2005). 45-47.

Gerber, David. "Creating Group Identity: Disabled Veterans and the American Government," Organization of American History Magazine Vol. 23, No. 3 (July 2009).

Hacker, David J., “A Consensus Based Count of the Civil War Dead." Civil War History, wVol. 57, no. 4 (December 2011): 307-348.

Halttunen, Karen. "Humanitarianism and the Pornography of Pain in AngloAmerican Culture." American Historical Review, (April 1995): 303-334.

Hess, Earl. "Tell me What the Sensations Are," In Union Soldiers and the Northern Home Front, ed. Paul Cimbala and Randall Miller. New York: Fordham University, 2002.

Paul H. "A Volunteer Nurse in the Civil War: Letters of Harriet Douglas Whetten," Wisconsin Magazine of History 48 (1964).

Keeney, Elizabeth Barnaby. "Unless Powerful Sick: Domestic Medicine in the Old South," in Science and Medicine in the Old South, ed. Ronald Numbers and Todd L. Savitt. Baton Rouge: Louisiana State University Press, 1989.

Kudlick, Catherine. "Disability History: Why We Need Another 'Other.'" The American Historical Review 108, no. 3 (2003): 763-792.

Mihm, Stephen. “'A Limb Which Shall Be Presentable in Polite Society': Prosthetic Technology in the Nineteenth Century," in Artificial Parts, Practical Lives: Modern Histories of Prosthetics. ed. Katherine Ott, David Serlin, and Stephen Mihm. New York: New York University Press, 2002.

Parkes, Murray Colin. "Psycho-Social Transitions: Comparison between Reactions to Loss of a Limb and Loss of a Spouse," British Journal of Psychiatry 127, 1975.

Pelka, Fred. "Although Crippled in Body, the Soldiers in the Veteran Reserve Corps Were Whole and Strong in Spirit." America's Civil War, Sept. (1994): 23, 80.

Ross, Kristie. “Arranging a Doll's House: Refined Women as Union Nurses," in Divided Houses: Gender and the Civil War. ed. Catherine Clinton and Nina Silber. New York: Oxford University Press, 1992.

Sandell, Richard, Annie Delin, Jocelyn Dodd, and Jackie Gay. "In the Shadow of the 
Freakshow: The Impact of Freakshow Tradition on the Display and Understanding of Disability History in Museums." Disability Studies Quarterly, 25, no. 4: 39-62.

Shultz, Richard. "Inhospitable Hospital: Gender and the Professionalism in Civil War Medicine.” Signs (Winter 1992).

Stinson, Byron. Civil War Times Illustrated. May 1971.

Wickberg, Daniel. "What is the History of Sensibilities? On Cultural Histories, Old and New." in American Historical Review (June 2007): 661-684.

Wood, Ann Douglas. "The War Within a War: Women Nurses in the Union Army." Civil War History 18, no. 3 (Sept. 1972), 197-212.

Wilson, Daniel J. “Teaching Disability History," Organization of American Historians Magazine of History. Vol 23, No. 3. (July 2009).

\section{Dissertation:}

Smith, Bennet. The Women Who Went to War: The Union Army Nurse in the Civil War. Ph.D. diss., Northwestern University 1981.

Suplick, Michael Stanley. United States Invalid Corps/Veteran Reserve Corps. Ph.D. diss., University of Minnesota, 1969.

\section{Reviews:}

Garland-Thomson, Rosemarie. Review of Monsters: Human Freaks in America's Gilded Age ed. Michael Mitchell and Extraordinary Exhibitions, Ricky Jay.

Rutkow, Ira. Review of John H Brinton Personal Memoirs: Civil War Surgeon, 18611865. Bulletin of the History of Medicine, 71.3 (1997): 534-535.

\section{Speech:}

Brinton, John H. "Address to the Members of the Graduating Class of the Army Museum: Closing Exercises of the Session 1895-96, Army Medical School." John H. Brinton Manuscript Collection. Record Group 124, OHA, National Museum of Heath and Medicine.

Lincoln, Abraham. Second Inaugural Address. March 4, 1865. 


\section{Newspapers:}

“American vs. European Medical Science.” Editorial. Medical Record 4 (May 15, 1869).

Allen, George A. The Antietam Waverly. March 29, 1890.

“The Exhibition at the Masonic Hall.” Charleston Courier. January 21, 1843.

“Homes for Discharged Invalid Soldiers.” United States Magazine, September 1864.

New York Times. July 27, 1861.

"Pretended Invalids in the Army," Detroit Advertiser and Tribune. October 21, 1863.

Rockingham Register, July 4, 1862.

Schurz, Carl. "The Battle of Gettysburg," McClure's Magazine, vol. XXIX, May to October 1907.

“Sympathy of the Body with an Amputated Member," New York Times, July 17, 1860.

\section{Online Sources:}

Adams, Rachel. "Caught Looking." A Cabinet of Curiosities. Vol. 4, No. 2, (Jan 2004). www.commonplace.org

"Barnum's American Museum.” The Lost Museum Archive available from http://chnm.gmu.edu/lostmuseum/lm/163/.

Cook, James. "Race and Relations in P.T. Barnum's New York City." The Lost Museum Archive. http://chnm.gmu.edu/lostmuseum/lm/117/.

Gallagher, Gary “Darden Leadership Ride Elective Course.” Darden. 1 Apr. 2013. www.youtube.com.

Hyrkl Collection. The Mütter Museum. http://muttermuseum.org/about/history/.

Isenberg, Nancy. "Women's Rights Movements," The Oxford Companion to United States History. Paul S. Boyer, ed. 8, Sept. 2015. http://www.anb.org/cush rights.html

Pittman, Taylor. "Lego Has A Wheelchair for Its Figures. But Some Parents Are Still Unhappy." The Huffington Post. 31 Jul. 2015; accessed on August 24, 2015. http://www.huffingtonpost.com. 
"PTSD: National Center for PTSD" (ND) United States Department of Veteran Affairs Accessed Friday September 11, 2015. http://www.ptsd.va.gov/public/PTSD-overview/basics/how-common-isptsd.asp

Michael Sappol, "Morbid Curiosity: The Decline and Fall of the Popular Anatomical Museum." A Cabinet of Curiosities. Vol. 4, No. 2, (Jan 2004). www.commonplace.org

Shinn, Christopher. "Disability is not just a Metaphor," The Atlantic. 23 Jul.2014; accessed on August 24, 2015. http://www.theatlantic.com. 